\title{
Cellular membrane trafficking of mesoporous silica nanoparticles
}

\author{
by \\ I-Ju Fang \\ A dissertation submitted to the graduate faculty \\ in partial fulfillment of the requirements for the degree \\ DOCTOR OF PHILOSOPHY
}

\author{
Major: Chemistry \\ Program of Study Committee \\ Brian G. Trewyn, Major Professor \\ Ning Fang, Co-Major Professor \\ Marek Pruski \\ Emily Smith \\ Nicola L. Pohl
}

Iowa State University

Ames, Iowa

2012

Copyright $($ I-Ju Fang, 2012. All rights reserved 


\section{TABLE OF CONTENTS}

$\begin{array}{lr}\text { ABSTRACT } & \text { iv } \\ \text { DISSERTATION ORGANIZATION } & \mathrm{V} \\ & \\ \text { CHAPTER 1. GENERAL INTRODUCTION } & 1 \\ \text { Abstract } & 1 \\ \text { Introduction } & 1 \\ \text { Intracellular delivery into animal cells utilizing MSN } & 3 \\ \text { Delivery into plant cells utilizing MSN } & 14 \\ \text { Testing biological interactions of MSN on animal cells } & 19 \\ \text { References } & 24\end{array}$

CHAPTER 2. LIGAND CONFORMATION DICTATES MEMBRANE AND ENDOSOMAL TRAFFICKING OF ARGININE-GLYCINE-ASPARTATE (RGD)FUNCTIONALIZED MESOPOROUS SILICA NANOPARTICLES

$\begin{array}{ll}\text { Abstract } & 28\end{array}$

Introduction $\quad 29$

Experimental Section $\quad 30$

Results and Discussion $\quad 38$

Conclusions $\quad 54$

References $\quad 55$

CHAPTER 3. THE STUDY OF FUNCTIONALITY OF MAGNETIC MESOPOROUS SILICA NANOPARTICLES ON CELLULAR PROTEIN SEQUESTRATION

$\begin{array}{ll}\text { Abstract } & 57\end{array}$

$\begin{array}{ll}\text { Introduction } & 57\end{array}$

$\begin{array}{ll}\text { Experimental Section } & 62\end{array}$

Results and Discussion $\quad 68$

$\begin{array}{ll}\text { Conclusions } & 76\end{array}$

$\begin{array}{ll}\text { References } & 77\end{array}$

CHAPTER 4. THE PROGRAMMABLE ENDOCYTOSIS BEHAVIOR OF MESOPOROUS SILICA NANOPARTICLES

$\begin{array}{ll}\text { Abstract } & 83\end{array}$

$\begin{array}{ll}\text { Introduction } & 84\end{array}$

Experimental Section $\quad 89$

Results and Discussion $\quad 95$

$\begin{array}{lr}\text { Conclusions } & 105\end{array}$

$\begin{array}{ll}\text { References } & 106\end{array}$ 
CHAPTER 5. GENERAL CONCLUSIONS ACKNOWLEDGEMENTS 


\begin{abstract}
This dissertation mainly focuses on the investigation of the cellular membrane trafficking of mesoporous silica nanoparticles. We are interested in the study of endocytosis and exocytosis behaviors of mesoporous silica nanoparticles with desired surface functionality. The relationship between mesoporous silica nanoparticles and membrane trafficking of cells, either cancerous cells or normal cells was examined. Since mesoporous silica nanoparticles were applied in many drug delivery cases, the endocytotic efficiency of mesoporous silica nanoparticles needs to be investigated in more details in order to design the cellular drug delivery system in the controlled way.

It is well known that cells can engulf some molecules outside of the cells through a receptor-ligand associated endocytosis. We are interested to determine if those biomolecules binding to cell surface receptors can be utilized on mesoporous silica nanoparticle materials to improve the uptake efficiency or govern the mechanism of endocytosis of mesoporous silica nanoparticles. Arginine-glycine-aspartate (RGD) is a small peptide recognized by cell integrin receptors and it was reported that avidin internalization was highly promoted by tumor lectin. Both RGD and avidin were linked to the surface of mesoporous silica nanoparticle materials to investigate the effect of receptor-associated biomolecule on cellular endocytosis efficiency. The effect of ligand types, ligand conformation and ligand density were discussed in Chapter 2 and 3.

Furthermore, the exocytosis of mesoporous silica nanoparticles is very attractive for biological applications. The cellular protein sequestration study of mesoporous silica nanoparticles was examined for further information of the intracellular pathway of endocytosed mesoporous silica nanoparticle materials. The surface functionality of
\end{abstract}


mesoporous silica nanoparticle materials demonstrated selectivity among the materials and cancer and normal cell lines. We aimed to determine the specific organelle that mesoporous silica nanoparticles could approach via the identification of harvested proteins from exocytosis process.

Based on the study of endo- and exocytosis behavior of mesoporous silica nanoparticle materials, we can design smarter drug delivery vehicles for cancer therapy that can be effectively controlled. The destination, uptake efficiency and the cellular distribution of mesoporous silica nanoparticle materials can be programmable. As a result, release mechanism and release rate of drug delivery systems can be a well-controlled process. The deep investigation of an endo- and exocytosis study of mesoporous silica nanoparticle materials promotes the development of drug delivery applications. 


\section{DISSERTATION ORGANIZATION}

This dissertation is composed of five chapters. Chapter 1 is a review focusing on the application of mesoporous silica nanoparticle materials in intracellular drug delivery of molecules and proteins. Topics are related to the cellular delivery of molecules or proteins into animal or plant cells. The drugs, dyes, cell membrane impermeable macromolecules (proteins or DNA) can be delivered by utilizing mesoporous silica nanoparticles as transportation vehicles. Chapter 2 is a journal article accepted by Chemistry - A European Journal. The importance of ligand conformation and density of a small peptide RGD on the association of cell surface receptor integrin was highlighted. Chapter 3 and 4 are ready for submission. Chapter 3 is a study of selective intracellular protein sequestration and removal from cells utilizing differently surface functionalized magnetic mesoporous silica nanoparticle materials. Chapter 4 is a study investigating to linkage of biomolecules onto mesoporous silica nanoparticles surface via biotin-avidin interaction. The biotin moiety on mesoporous silica nanoparticles is the ligand for avidin. With noncovalent immobilization of avidin, the endocytosis behavior of mesoporous silica nanoparticles are manipulated by immobilized protein types, protease, and thiol reducing reagent. Chapter 5 is a general conclusion summarizing the importance of this research done in this dissertation. 


\title{
CHAPTER 1. GENERAL INTRODUCTION
}

\section{APPLICATION OF MESOPOROUS SILICA NANOPARTICLES IN INTRACELLULAR DRUG DELIVERY}

Modified from a chapter published in Methods in Enzymology 2012, vol 508, 41-59

I-Ju Fang and Brian G. Trewyn

\begin{abstract}
Delivery of drugs and molecules to eukaryote animal and plant cells can be enhanced when mediated by mesoporous silica nanoparticle (MSN) materials. We describe, in detail, the synthesis of several different MSN materials used for the transport of drug molecules, neurotransmitters, macromolecules, etc. across the cell membrane, and in some cases, plant cell walls. We also summarized several considerations that need to be addressed when utilizing MSN materials with biological systems to avoid complicating experiments.
\end{abstract}

\section{Introduction}

Transporting drugs and molecules through cell membranes has recently been the topic of a significant amount of research in the area of drug delivery and controlled release. ${ }^{1-4}$ Several different types of drug carriers or "vehicles" have been developed for this task including polymers, liposomes, dendimers, and inorganic nanoparticles. ${ }^{5-9}$ Utilizing these vehicles has several advantages over conventional dosage methods including decreased drug inactivation, increased efficacy, and reduced non-specific interactions to name just a 
few. One type of inorganic nanoparticle that has been successfully applied as a controlled-release drug delivery system is mesoporous silica nanoparticle (MSN) materials. $^{10-15}$ In the early 1990 s mesoporous silica materials were discovered independently by researchers at the Mobil Oil Corporation in the US and by researchers at Waseda University in Japan. ${ }^{16-18}$ The unique characteristics of MSN material make it ideal for applications in catalysis, separations, sensors, and drug delivery. ${ }^{19-21}$

The delivery of small molecules (neurotransmitters and anticancer drugs) and large biomolecules (proteins and DNA) into animal and plant cells has been demonstrated by utilizing MSN material as the transport vehicle and by taking advantage of the endocytic character of MSN materials. Due to the unique system of parallel, individual pores, the MSN nanocarrier system has demonstrated "zero release" of drugs prior to the MSN carriers reaching the targeted cells (Figure 1). ${ }^{22}$ In certain instances, MSN based drug delivery systems are triggered by external stimuli and release their cargo at the desired destination. Because of the nature of the cargo, the interior and exterior surface of

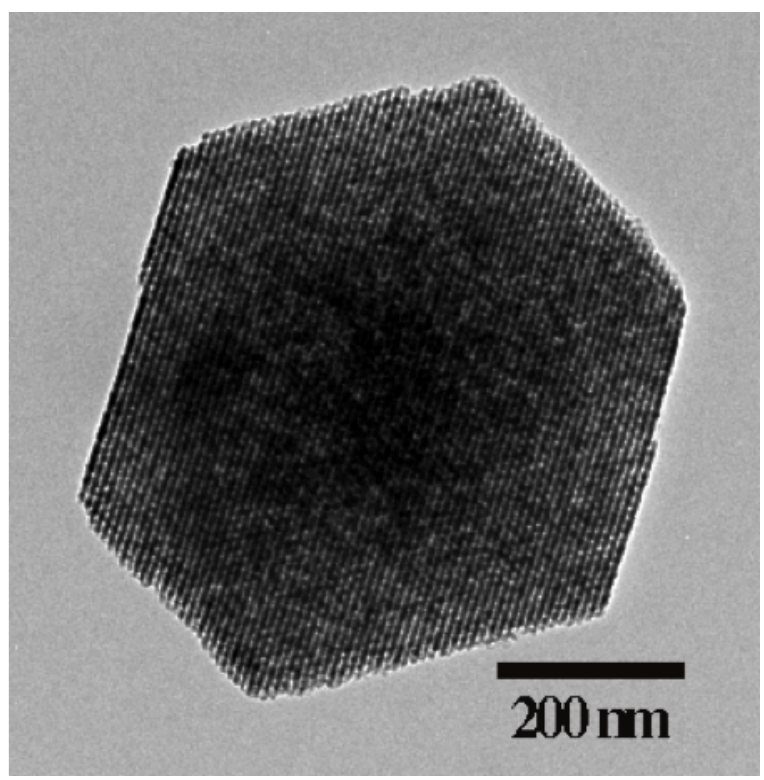

Figure 1. Transmission electron micrograph of a mesporous silica nanoparticle. the MSN needs to be specifically functionalized for the purpose of drug delivery. The key points and related syntheses are discussed in detail below. 


\section{Intracellular delivery into animal cells utilizing MSN}

Several reports have demonstrated the uptake of MSN material by eukaryote cells through endocytosis processes. The process of MSN internalization makes it possible to utilize this unique delivery vehicle to deliver many different types of molecules efficiently. One particular area of interest is in the uptake of cell membrane impermeable molecules that cannot be internalized by cells directly through standard dosage means. With the help of MSN materials, procedures have been developed to increase the efficiency of animal and plant cell uptake of various molecules.

\section{Delivery of drugs}

Regular pore MCM-41-type MSN material has several characteristics as drug and molecule delivery and controlled release devices that distinguish it from other systems, including a high surface area $\left(>800 \mathrm{~m}^{2} \mathrm{~g}^{-1}\right)$, an easily tunable pore size $(2-10 \mathrm{~nm})$, and unique functional surface chemistry. ${ }^{16}$ These MSN structural properties make it a desirable material for loading, delivering, and releasing drugs in controlled manners. The drugs that are loaded and released are unique and require specific MSN properties. One such example of molecular properties that need to be addressed with utilizing MSN materials for drug delivery is the hydrophilic or hydrophobic nature of the drug/molecule. Different strategies for the synthesis of MSNs, the drug loading, and the drug release are adapted to optimize the utility of MSN.

For hydrophilic drugs, the delivery of a neurotransmitter (ATP) and an antibiotic (vancomycin) to astrocyte cells by pore-capped MSN materials has been demonstrated. ${ }^{23}$ 

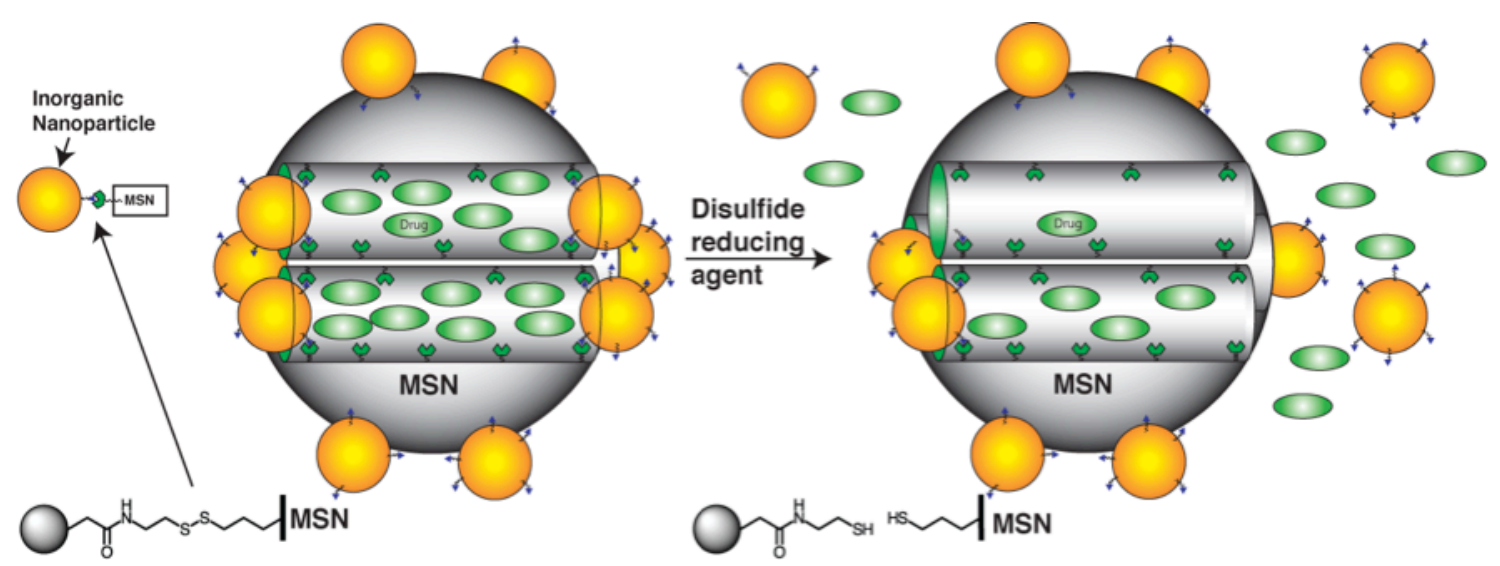

Figure 2. Schematic representation of the designed stimuli-responsive drug loading, capping, and release system mediated by mesoporous silica nanoparticle materials. Examples of inorganic nanoparticles that have been successfully employed as pore caps include cadmium sulfide, iron oxide, and gold.

The procedures for the synthesis of drug loaded, cadmium sulfide nanoparticle (CdS) capped MSN were completed as follows: 2-(propyldisulfanyl) ethylamine functionalized mesoporous silica nanosphere (linker-MSN) were synthesized as the core MSN support with a disulfide reducible ligand. The CdS nanoparticles were ligated with mercaptoacetic acid to produce acid-CdS nanoparticles, whose monodispersed size is compatible with the regular pore size of MSNs through an amidation reaction (Figure 2). The most important aspect of this type of nanoparticle based controlled release system was the cleavable disulfide bond triggered by dithiothreitol (DTT) and mercaptoethanol (ME). As a result of this complete capping, no drug leakage occurred until the MSN material was exposed to a disulfide reducing agent. The linker-MSN (100 mg) was dispersed in a PBS solution $(\mathrm{pH}$ 7.4) of ATP or vancomycin at a concentration of $5 \mathrm{mM}$ for $24 \mathrm{~h}$. The mercaptoacetic acid-functionalized CdS nanoparticles $(0.15 \mathrm{mmol})$ were dissolved in $2 \mathrm{~mL}$ of PBS with a constant concentration of vancomycin or ATP to prevent drug diffusion from MSN pores. The amide linking agent, 1-[3(dimethylamino)propyl]-3-ethylcarbodiimide hydrochloride (EDC) $(57.5 \mathrm{mg})$, was 
introduced to the $\mathrm{CdS} / \mathrm{drug}$ mixture solution. The reaction mixture was stirred for $24 \mathrm{~h}$, followed by centrifuging for $3 \mathrm{~min}$. The resulting products obtained were ATP- or vancomycin-loaded, CdS-capped MSN with loading densities of 83.9 and $30.3 \mathrm{~mol} \%$ for vancomycin and ATP, respectively. This system successfully released neurotransmitters triggered by perfusion of mercaptoethanol in the presence of astrocytes that caused an increase in the concentration of intracellular $\mathrm{Ca}^{2+}$ ion. In addition to the CdS nanoparticle caps, we developed iron oxide nanoparticle capped MSN (magnet-MSN) as nanocarriers, that made the entire system magnetic and, after cellular internalization, cells can be moved under the control of a magnetic field. ${ }^{24}$

In another system, the MSN mediated intracellular delivery of cysteine (Cys) was demonstrated ${ }^{25}$. Cysteine is toxic and not stable in the extracellular matrix so the cargo, Cys, was covalently bound to the interior of thiol functionalized MSN through a disulfide bond bridge (Cys-MSN). This disulfide bond between Cys and MSN material was reduced by the intracellular antioxidants, including nicotinamide adenine dinucleotide hydride (NADH), dihydrolipoic acid (DHLA), and glutathione. Cys molecules were released from MSN material into the cytoplasm. Potentially, Cys-MSN can be applied to several chronic inflammation disorders caused by low intracellular concentrations of glutathione.

Because the silanol-based surface of MSN material is very hydrophilic, there is low affinity for the adsorption of hydrophobic drugs that are only slightly water-soluble. This hydrophobic characteristic is common among most anticancer drugs and adds complications to their use. Anionic surfactant templated MSNs were designed for the delivery of some of these hydrophobic drugs. ${ }^{26}$ The anticancer drug resveratrol was used 
as the guest molecule to demonstrate the potential delivery system. The anionic surfactant was used as a template to form the pore framework in order to create a hydrophobic environment inside the MSN pores with high affinity of resveratrol. The release of resveratrol was surfactant-assisted, the surfactant template diffused from the pores with the resveratrol cargo when MSN material was dispersed in dilute PBS solution (Figure 3).
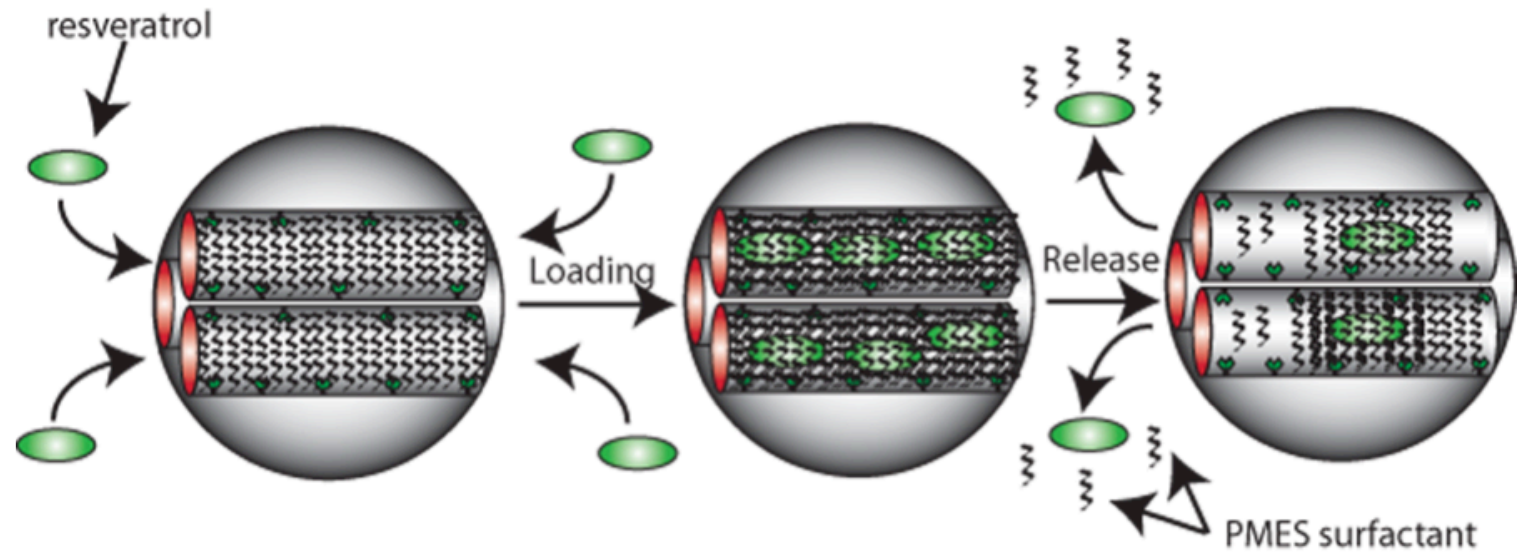

Figure 3. Schematic representing the process of loading resveratrol in to PMES-MSN and the release of the drug along with PMES surfactant.

For the synthesis of the anionic surfactant templated MSN material, the structure directing agent, undec-1-en-11-yltetra(ethylene glycol) phosphate mono-ester surfactant (PMES, $0.5 \mathrm{mmol}$ ) was dissolved in $100 \mathrm{~mL}$ of nanopure water and stirred vigorously at $80{ }^{\circ} \mathrm{C}$ for $1 \mathrm{~h}$. Then, aminopropyltrimethoxysilane (APTMS) was injected dropwise into the solution, followed by the addition of tetraethylorthosilicate (TEOS, $4.5 \mathrm{mmol}$ ) at the rate of $20 \mathrm{~mL}$ per hour. The reaction solution was stirred vigorously at $80^{\circ} \mathrm{C}$ for $10 \mathrm{~min}$ and then aged at $80{ }^{\circ} \mathrm{C}$ for $24 \mathrm{~h}$. The as-made product, PMES-MSN, was isolated by filtration, washed with nanopure water and methanol, and dried under vacuum at room temperature overnight. Loading resveratrol followed the synthesis and characterization of PMES-MSN by dissolving $0.05 \mathrm{mmol}$ resveratrol in $100 \mathrm{~mL}$ of $10 \%$ ethanol in water. PMES-MSN (300 mg) were added to $30 \mathrm{~mL}$ of this solution and stirred for $24 \mathrm{~h}$ at room 
temperature. To avoid the photo-isomerization of resveratrol under UV light the material was protected from light. Resveratrol was released from the pores of PMES-MSN when dispersed in dilute PBS and stirred at room temperature.

\section{Double delivery of drugs}

One unique advantage of MSN material is the intrinsic nanoparticle morphology of two independent surfaces. MSN materials have an interior pore surface and an exterior surface that can be selectively and independently functionalized. Thus, MSN material can co-deliver chemical, protein and genomic material, utilizing these surfaces of the MSN. For example, the pores of MSN were loaded with cyclic adenosine monophosphate (cAMP) and capped with a sugar derivative of insulin protein (Figure $4 a){ }^{27}$ The unique mechanism that we designed for this co-delivery system allowed for both the insulin and cAMP to be released dependent upon the concentration of extracellular glucose. Using

a)

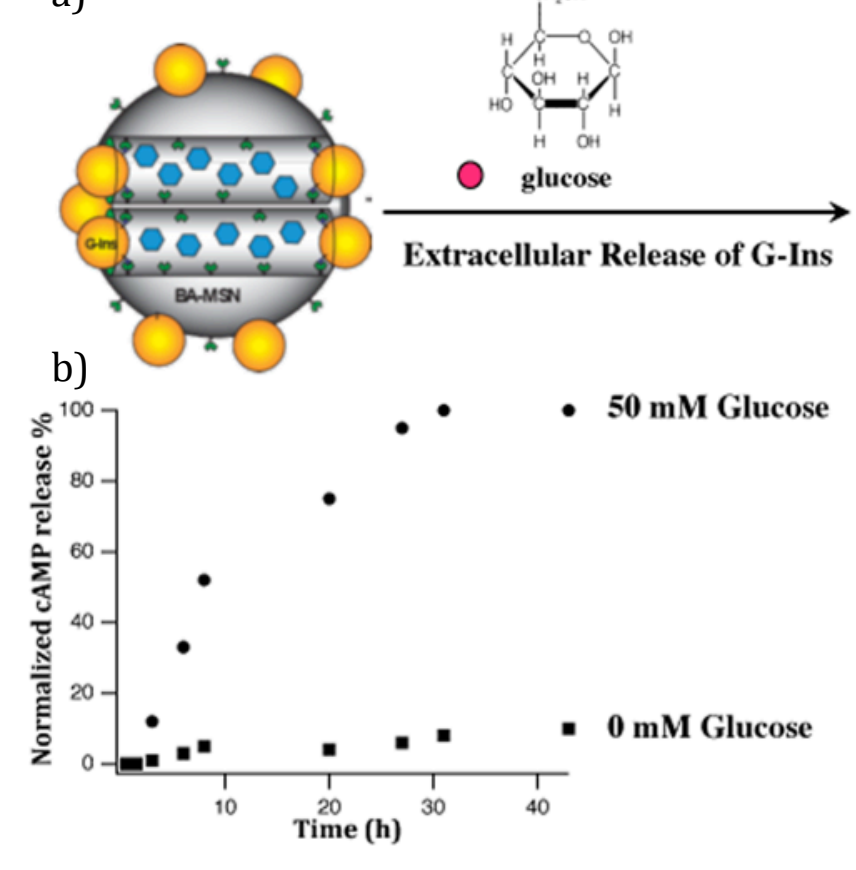

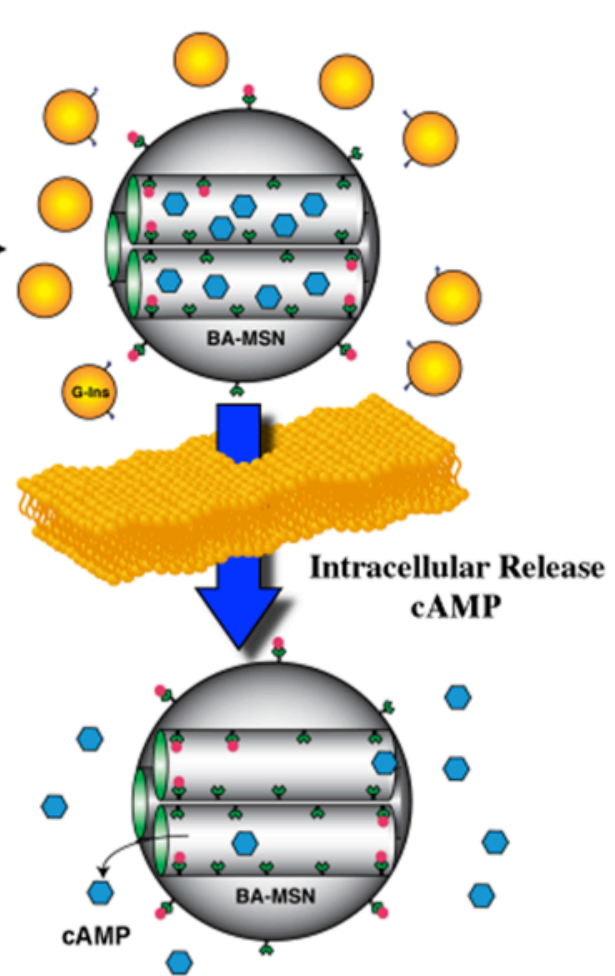

Figure 4. Schematic representation of the [glucose] dependent extracellular release of G-Ins and the intracellular release of cAMP (a) and a quantitative display of the [glucose] dependant release of cAMP (b). 
this insulin bonding scheme, the concentration of glucose manipulated the kinetics of release of insulin and cyclic AMP. The insulin was covalently bound to the MSN surface by the binding between the phenylboronic acid of MSN exterior and the vicinal diols of insulin. This type of binding is reversible in high concentrations of glucose. The insulin capped cAMP loaded MSNs were an efficient self-regulated device for the concentration of glucose.

To synthesize the phenylboronic acid functionlized MSNs (BA-MSNs), aminopropyl functionalized MSN (AP-MSN) was used as the precursor for the further derivativization of the boric acid group on MSN surface. The AP-MSN (400 mg) was dispersed in $20 \mathrm{~mL}$ DMSO and $0.9 \mathrm{mmol}$ 4-carboxyphenylboronic acid (CBA) was activated with $0.9 \mathrm{mmol}$ N-hydroxysuccinimide (NHS) and 1 mmol 1-ethyl-3-(3-dimethylaminopropyl) carbodiimide hydrochloride (EDC) in $5 \mathrm{~mL}$ DMSO, stirring at room temperature for at least 15 min before adding it to the AP-MSN suspension. The mixture was stirred at room temperature overnight, followed by filtration and washing with DMSO, water and methanol to remove excess CBA.

Insulin was gluconic acid functionalized according to the literature (G-Ins), and was further labeled with fluorescein dye (FITC) for in vitro controlled release studies. ${ }^{28}$ G-Ins (200 mg) was dissolved in $50 \mathrm{~mL}$ sodium carbonate buffer $(0.1 \mathrm{M}$, pH 9) and then reacted with $2.5 \mathrm{~mL}$ FITC in DMSO at $1 \mathrm{mg} \mathrm{mL}^{-1}$ was added while the G-ins solution was stirred in dark to avoid fluorescence quenching. The reaction was stirred for another $2 \mathrm{~h}$ at room temperature until $1 \mathrm{M} \mathrm{NH}_{4} \mathrm{Cl}$ was added to quench excess FITC. After stirring for $1 \mathrm{~h}$, the solution was dialyzed in phosphate-buffered saline and freeze-dried to obtain FITC labeled G-Ins (FITC-G-Ins). The ratio of FITC to G-ins was estimated by 
measuring the absorbance ratio between $495 \mathrm{~nm}$ and $280 \mathrm{~nm}$ corresponding to the absorption band for fluorescein and G-Ins, respectively.

To load cAMP into the mesopores and cap with G-Ins, the BA-MSN (100 mg) was stirred in $1 \mathrm{mM}$ cAMP solution (10 mL PBS, $154 \mathrm{mM}, \mathrm{pH} 7.4)$ for $24 \mathrm{~h}$ in the dark. Then, FITC-G-Ins (200 mg) was added to the suspension and the mixture was stirred in dark overnight, followed by filtration and extensive washing with PBS to remove physically adsorbed cAMP and non-associated FITC-G-Ins from the exterior surface of the MSN material. The resulting precipitate was isolated and dried under high vacuum. The loading of cAMP and FITC-G-Ins was calculated by subtracting the amount of cAMP/FITC-Ginsulin remaining in the supernatant from the amount of cAMP/FITC-G-insulin originally in the reaction mixture.

Cyclic AMP loaded FITC-G-Ins-MSN (6 mg) was dispersed in $3 \mathrm{~mL}$ of PBS with the introduction of different concentrations of glucose triggers. Aliquots $(1.5 \mathrm{~mL})$ were removed after stirring for two days in the dark at room temperature, followed by separation by centrifugation. To measure the kinetics of release, cAMP loaded FITC-GIns-MSN (30 mg) was dispersed in $15 \mathrm{~mL}$ of PBS with $50 \mathrm{mM}$ glucose (Figure $4 \mathrm{~b}$ ). Aliquots $(1.2 \mathrm{~mL})$ were removed at the specific time intervals from the suspension, followed by centrifugation. The release kinetics of FITC-G-Ins and cAMP were monitored by fluorescence emission spectroscopy and HPLC, respectively.

\section{Delivery of cell membrane impermeable macromolecules}

Most macromolecules cannot penetrate cell membranes through an endocytic pathway because of their size and/or charge. However, MSN materials can be used as carriers to promote the cellular internalization of macromolecules. Cell membrane 
impermeable proteins and polysaccharides were delivered into cells by the aid of MSN materials utilizing recently developed large pore MSN synthesis techniques that contain these macromolecules in the mesopore framework. There are two types of large pore MSN materials: one is MCM-41 type and the other is SBA-15 type. ${ }^{16,29}$

MCM-41-type MSN with large pore diameter $(5.4 \mathrm{~nm})$ is synthesized for the intracellular delivery of cell membrane impermeable protein cytochrome $c$ by employing mesitylene, a pore-expanding agent, used in conjunction with the traditional MCM-41 surfactant template. ${ }^{30}$ The activity of released cytochrome $c$ remained after loading and releasing from the pores of the MSN.

To synthesize MCM-41-type large pore MSN, cetyltrimethylammonium bromide (CTAB, $2.7 \mathrm{mmol}$ ) was dissolved in a solution of $480 \mathrm{~mL}$ water and $3.5 \mathrm{~mL}$ of $2 \mathrm{M}$ $\mathrm{NaOH}$, followed by addition of mesitylene $(48.8 \mathrm{mmol})$ to the solution. The mixture was stirred vigorously until the solution was stable at $80{ }^{\circ} \mathrm{C}$. Tetraethyl orthosilicate (21.9 mmol) was then introduced to the solution dropwise at a rate of $1 \mathrm{~mL} \mathrm{~min}{ }^{-1}$. The reaction mixture was stirred at $80{ }^{\circ} \mathrm{C}$ for $2 \mathrm{~h}$. The resulting white precipitate (as-made MSN) was isolated by filtration, washed with methanol, and dried under vacuum at high temperature $\left(100{ }^{\circ} \mathrm{C}\right)$ for $12 \mathrm{~h}$. The structure-template surfactant, $\mathrm{CTAB}$, and mesitylene were removed from the pores of the as-made MSN by acid extraction. A suspension of $1.0 \mathrm{~g}$ of the as-made MSN material was stirred for $6 \mathrm{~h}$ at $50{ }^{\circ} \mathrm{C}$ in a $100 \mathrm{~mL}$ methanol with 0.75 $\mathrm{mL}$ concentrated hydrochloric acid. The template-free solid product was then isolated via filtration and dried under vacuum at room temperature for $12 \mathrm{~h}$. For loading of FITClabeled cytochrome $c$ into the pores of the MSN, $5 \mathrm{~mL}$ of the protein solution ranging from 0.4 to $8 \mathrm{mg} \mathrm{mL}^{-1}$ in PBS were stirred for $6 \mathrm{~h}$ at room temperature with $20 \mathrm{mg}$ of 
MSN. The suspensions were centrifuged and the loading was determined by measuring the difference in absorption of the Soret band of cytochrome $c$ at $410 \mathrm{~nm}$ in the supernatant before and after loading. The isolated protein-MSN composites were dried under vacuum in the dark at room temperature to avoid fluorescence quenching for $12 \mathrm{~h}$.

Suspensions of the FITC-cytochrome $c$-loaded MSN in PBS were prepared at the concentration of $100 \mu \mathrm{g} \mathrm{mL}^{-1}$. The release of FITC-cytochrome $c$ from MSN materials was monitored by UV-Vis.

Large pore MSN can accommodate the loading of several large macromolecules that are too large for standard MCM-41 type MSN. Dextran is a polysaccharide complex that has a dynamic diameter of approximately $8 \mathrm{~nm}$. Mesoporous polymer-silica hybrid nanoparticles were synthesized for the delivery of macromolecules, like dextran, into cells ${ }^{31}$. A uniform, thin polymer layer was formed on the MSN surface upon the addition and heat treatment of the polymer monomer (methacrylic acid (MAA)). When dextran was loaded into polymethacrylic acid-coated MSN (PMAA-MSN) at low pH (lower than 5), a stable complex between PMAA-MSN and dextran was formed because of the hydrogen bonding interactions occurring between carboxylic acid groups on the PMAA and the hydroxyl group of dextran. However, the hydrogen bond would be diminished when the MAA becomes deprotonated at $\mathrm{pH}$ levels greater than the $\mathrm{pKa}$ of polymethacrylic acid $(\mathrm{pKa}=4.85)$. Polymer-silica nanoparticles are biocompatible and have demonstrated to be efficiently engulfed by cells. As a result the PMAA layer on MSN played an important role in controlling the loading and release of dextran. At low $\mathrm{pH}$, dextran was loaded into PMAA-MSNs and then released in higher $\mathrm{pH}$, such as intracellular $\mathrm{pH}$. 
For the synthesis details, the large pore SBA-15 type MSN materials were synthesized as follows. First, a triblock copolymer Pluronic P104 $\left(\mathrm{EO}_{27} \mathrm{PO}_{61} \mathrm{EO}_{27} ; 7 \mathrm{~g}\right)$ was dissolved in a $1.6 \mathrm{M} \mathrm{HCl}$ aqueous solution (270 g), the temperature was stabilized at $56{ }^{\circ} \mathrm{C}$ and tetramethyl orthosilicate (10.6 g) was quickly added into the solution. Uniquely to this MSN material, temperature is an important parameter in controlling the particle and pore morphology. After stirring for $24 \mathrm{~h}$, the reaction solution was transferred to a Teflon-lined high-pressure autoclave for hydrothermal treatment at $150{ }^{\circ} \mathrm{C}$ for $24 \mathrm{~h}$. The resulting large pore MSN product was isolated by filtration, washed with water and methanol, and dried under high temperature. The template removal of MSN was conducted through a high-temperature calcination process at $550{ }^{\circ} \mathrm{C}$. To form a uniform polymer layer on the interior surface of MSN material, the methacrylic acid monomer (MAA; $0.190 \mathrm{~g}$ ), ethylene dimethacrylate cross-linker (EDMA; $0.11 \mathrm{~g}$ ), and radical initiator $\alpha, \alpha^{\prime}$-azoisobutyronitrile (AIBN; $16 \mathrm{mg}$ ) were dissolved in $1.25 \mathrm{~mL}$ of dichloromethane. The monomer diffused into the mesopores of the large pore MSN (1 g) via a wet impregnation method. After $2 \mathrm{~h}$ of drying at $40{ }^{\circ} \mathrm{C}$ in order to remove the dichloromethane, the mixture was transferred into a Schlenk reactor and subjected to freeze-vacuum-thaw cycles three times with liquid nitrogen. The mixture was kept at $35{ }^{\circ} \mathrm{C}$ for $6 \mathrm{~h}$ under vacuum, and the polymerization of MAA was performed at $60{ }^{\circ} \mathrm{C}$ for $6 \mathrm{~h}, 100{ }^{\circ} \mathrm{C}$ for $1 \mathrm{~h}$, and $120^{\circ} \mathrm{C}$ for $1 \mathrm{~h}$. The product, PMAA-MSN, was washed with chloroform and ethanol several times and dried at $80{ }^{\circ} \mathrm{C}$ under vacuum. The PMAAMSN hybrid materials were directly loaded with FITC-Dextran $(40 \mathrm{kDa})$ prepared in $\mathrm{pH}$ 3 buffer by mixing PMAA-MSN (3.2 mg) with $5 \mathrm{~mL}$ of the FITC-Dextran solution. After the suspension was stirred for $24 \mathrm{~h}$, the final product was centrifuged and washed with a 
buffer solution three times. The amount of FITC-Dextran loaded on the PMAA-MSN was determined by UV-Vis spectroscopy. The supernatant solution was analyzed at 451 $\mathrm{nm}$. The sample was dried under vacuum at room temperature.

The release profile of $40 \mathrm{kDa}$ FITC-Dextran from the PMAA-MSNs in a $\mathrm{pH} 7$ solution was measured at room temperature using the FITC-Dextran-loaded PMAA-MSN at $\mathrm{pH}$ 3. PMAA-MSN successfully delivered the dextran cargo into eukaryote cells.

\section{MSN Mediated Delivery of DNA}

Polyamidoamine (PAMAM) dendrimer has proven to be an efficient gene transfection reagent. Second generation PAMAM (G2-PAMAM) was used to complex DNA onto the exterior surface of MSN material. ${ }^{32}$ In detail, G2-PAMAM $(0.11 \mathrm{mmol})$ in ethanol was added to an isocyanatopropyl-functionalized MSN (ICP-MSN) suspension and stirred for $20 \mathrm{~h}$ to form covalent urea bonds between the primary amines of the PAMAM and the ICP groups of the MSN.

The results demonstrated that the G2-PAMAM-MSN could form a complex with plasmid DNA at weight ratios larger than 1:5. Also, the G2-PAMAM-MSN-DNA complex protects DNA from digestion by nuclease enzymes because of the shielding of PAMAM-MSN complex. Significant GFP expression was observed in the cytoplasm after G2-PAMAM-MSN-DNA complexes were internalized by cells. Once the complexes were internalized, the DNA was released from the surface of the PAMAMMSN and diffused into the cell cytoplasm. 


\section{Delivery into plant cells utilizing MSN}

As previously mentioned, surface functionalized MSN is often used as vehicles to transport guest molecules into animal cells, however utilizing MSN to carry guest molecules into plant cells is a much more challenging task. Compared to animal cells, the internalization of MSN into plant cells is limited because plant cells have a thick cellulose cell wall to give structure support and protection from environmental stress. To further investigate the endocytosis of MSN materials by plant cells, Lin, Wang, and coworkers developed a MSN technology to study the endocytosis of MSN and delivery of chemicals and genomic material into plant cells and plant protoplasts (cells with the cell wall enzymatically removed). ${ }^{33}$ For plant cells without cell walls, MSN could be directly internalized into the cytoplasm and deliver and release DNA, which was subsequently expressed. For plant cells containing cell walls, a gene gun bombardment technique is necessary to get the MSN through the cell wall and into plant cells (Figure 5a). We will introduce some basic ideas for development MSN delivery systems for plant cells, how to apply MSN to plant science, and how to successfully deliver small drug molecules to plant cells in a controlled fashion.

\section{The study of endocytosis of MSN by plant protoplasts.}

Surface functionality of MSN material plays an instrumental role in the endocytosis of MSN by protoplast cells. Tagging the MSN material with FITC dye in a manner similar to that stated above allowed for observation of the dynamic distribution of MSN materials in plant cells. Protoplasts failed to internalize MSN materials that were not surface functionalized. However, a triethylene glycol (TEG) functional group covalently attached to the MSN surface made it possible for protoplasts to uptake MSN. 
a)

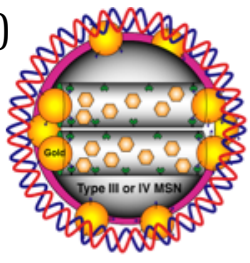

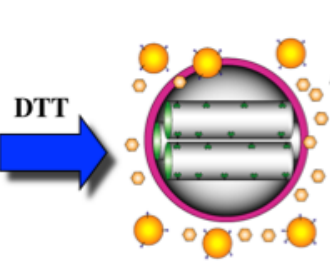
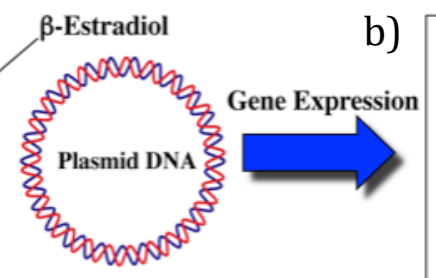

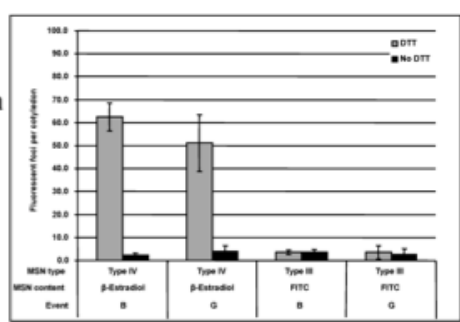

Figure 5. Illustration of the disulfide reducer controlled uncapping of MSN pores and the subsequent release of $\beta$-oestradiol (a) and the fluorescent foci per transgenic cotyledon grown in the presence (gray bars) and absence (black bars) of DTT (b).

The MSN material (200 $\mathrm{nm}$ in diameter) was covalently doped with fluorescein as described above to visualize the internalization of MSN by plant cells and protoplasts. To limit the diffusion of the TEG ligand into the pores, the exterior surface of the MSN was covalently coated with TEG by a post synthesis grafting method prior to acid extraction of the surfactant template. The synthesis of the TEG ligand was achieved by reacting the TEG precursor 1-[2-(2-bromo-ethoxy)-ethoxy]-2-methoxy-ethane with 3aminopropyltrimethoxysilane overnight in refluxing ethanol. The surfactant template was removed by acid extraction following successful attachment of the TEG ligand. The product of this reaction was directly available for endocytosis experiments.

Endocytosis experiments:

Protoplasts $\left(10^{6}\right.$ cells $\left.\mathrm{mL}^{-1}\right)$ were incubated with $10 \mu \mathrm{g}$ TEG coated FITC labeled MSN (TEG-FITC-MSN) in media overnight. To remove physically adsorbed TEG-FITCMSN that had not been internalized by the protoplasts, the mixtures were incubated with $\mathrm{K} 4$ medium and centrifuged for $10 \mathrm{~min}$ at $100 \mathrm{~g}$ at room temperature. Only protoplasts at the interphase were collected for analysis.

Although protoplasts could directly internalize TEG-FITC-MSN, the delivery of MSN materials to intact plant cells is more attractive and practical for plant research. For this reason, the synthesis and functionalization of MSN was modified to codeliver 
bioactive agents through the common gene gun bombardment method often used in the field.

\section{Gene gun bombardment}

Gene gun bombardment is a method for the physical introduction of DNA into plant cells containing cell walls. The gene gun is utilized to bombard the plant cell wall with many DNA coated metal particles by using compressed helium as the propellant. The metal particles commonly used for gene gun bombardment include gold, tungsten, palladium, rhodium, platinum and iridium. They are coated with DNA, accelerated by helium gas, and bombard the plant cells. The metal particles ( 0.45 to $1.5 \mu \mathrm{m}$ in diameter) punch holes in and pass through the cell wall and enter the plant cells, leaving the DNA cargo inside the cells. The DNA coated metal particles randomly bombard the cells, no targeting is currently possible with this method. For example, the metal particles are localized everywhere in the cell including the nucleus and cytoplasm. Once the DNA cargo diffuses from the surface of the metal carrier, it has the opportunity to influence the intracellular genetic process.

Density is an important property of the metals used for this process, pure silica particles cannot gain enough momentum with helium propellant to break through the cell wall. To combine the advantageous properties of gold particles (density, biocompatibility, and DNA affinity) with the highly porous framework of MSN, a new gold nanoparticle capped MSN system was designed and synthesized. To synthesize acid functional gold nanoparticles, hydrogen tetrachloroaurate (III) hydrate $\left(7.63 \times 10^{-4} \mathrm{~mol}\right)$ was dissolved in $15 \mathrm{~mL}$ methanol, followed by the quick introduction of $1.8 \times 10^{-3} \mathrm{~mol} 11$ mercaptoundecanoic acid and $3 \mathrm{~mL}$ acetic acid. Under vigorous stirring, $0.4 \mathrm{M}$ sodium 
borohydride in $30 \mathrm{ml}$ water was added dropwise. The desired 10-15 $\mathrm{nm}$ acid functionalized-gold nanoparticles were washed with methanol, ethyl ether, and water and dried under vacuum. These acidic gold nanoparticles were coupled to amino groups on the MSN surface by standard amidation linker chemistry. To coat the gene gun microcarrier with DNA, gold capped-MSN material was dispersed in ethanol with the DNA of interest, and the tube was vortexed. Once the gene gun microcarrier was loaded with DNA, it was immersed into liquid nitrogen immediately to avoid agglomeration of DNA-bound MSN material and freeze dry the sample before bombarding into the plant cells.

The unique porous structure of MSN makes it possible for the dual delivery of bioactive agents: chemicals and proteins in the porous framework and genomic material adsorbed to the gold nanoparticle-coated exterior. For example, the interior of the MSN can be loaded with a chemical promoter to increase the efficiency of gene expression and the exterior surface of MSN can be coated with plasmid DNA for the desired gene expression. In the past, only nucleic acids could be carried by the nonporous gold particles. The development of mesoporous silica nanoparticles technology in plant cells opened the door for co-delivery of DNA and its corresponding inducer. Furthermore MSN material was capped with gold nanoparticles by the cleavable disulfide bond linked amide bond. The intracellular delivery could be precisely controlled by the addition of DTT.

\section{Co-delivery of genetic material and its activator into plant cell}

Codelivery of chemicals and DNA was great step forward in the area of plant science genomic research. It opened the door for scientists to look into methods for control in 
plant gene transfection. We used the transformation process to deliver genetic components into plant cells by using DNA-bound gold nanoparticle-capped drug-loaded MSN.

The design of DNA delivery system:

MSN material was used as a vehicle to carry GFP plasmid DNA and its inducer $\beta$ oestradiol into plant cells. To retain the $\beta$-oestradiol in the pores, the MSN material was capped with gold nanoparticles, the synthesis of which is outlined above. To dictate the release of the $\beta$-oestradiol the gold nanoparticles were covalently linked to the MSN material by disulfide linkers that were reduced in the presence of disulfide reducing agents. Only DNA bound gold nanoparticles capped $\beta$-oestradiol loaded MSNs treated with DTT showed the GFP expression in the cytoplasm. Prior to DTT treatment, loaded drugs (gene inducer) are trapped inside the pores, and did not influence gene expression.

The MSN material with primary amine linkers containing a cleavable disulfide bond (linker-MSN) was synthesized as the MSN precursor for plant cell delivery. To load the pores with the plasmid activator, linker-MSN (100 mg) was mixed with $5.0 \times 10^{-2} \mathrm{M} \beta$ oestradiol at room temperature for $24 \mathrm{~h}$. To covalently cap the linker-MSN, the gold nanoparticles were functionalized with 11-mercaptoundecanoic acid. These gold nanoparticles were introduced into the MSN material suspension with the same concentration of the cargo molecules with the amide coupling reagent $(80 \mathrm{mg})$ for another $24 \mathrm{~h}$. Gold capped $\beta$-oestradiol loaded MSN material was isolated by washing and centrifuging prior to DNA coating. 
DNA/MSN coating:

To adsorb plasmid DNA to the surface of gold $(\mathrm{Au})$ capped $\beta$-oestradiol loaded MSN material, plasmid DNA $(1 \mu \mathrm{g})$ was mixed with 10 ug the MSN complex in $50 \mu$ water for $2 \mathrm{~h}$ at $23{ }^{\circ} \mathrm{C}$. The optimal ratio of DNA to MSN material was 1:10.

In summary, the codelivery of gene and its inducerr was achieved successfully by combining MSN technology with gene gun bombardment. The drug release was precisely controlled with DTT treatment. The GFP plasmid DNA was highly expressed in the plant cells (Figure 5b). This demonstrated a successful application of MSN based delivery systems to genetic engineering research in plant science.

\section{Testing biological interactions of MSN on animal cells}

To investigate biological interactions of MSN material on cells, some factors need to be taken in consideration. Some of these important issues are discussed below.

\section{Issues with serum and serum-free media on the uptake and cell interaction with MSNS}

Cells usually are cultured in media containing either horse or fetal bovine serum for proliferation. Cells take up essential nutrients from media including serum proteins. When cells were treated with MSN material, serum in the media caused an effect on the cellular behavior. Recently, serum-free media has been utilized during experiments with cells and MSN material to avoid this effect that occurs when serum is present. It is not entirely clear what causes this effect in the presence of serum but one hypothesis is that serum adsorbs to the surface of the MSN material, and interferes with the MSN/cell interaction or causes the MSN material to aggregate. What we know for certain is that, serum in the media decreased the uptake efficiency of MSN by all cell lines tested. The degree of nanoparticle aggregation in serum containing media influenced both the 
endocytosis efficiency and kinetics. In summary, MSN material was engulfed by cells more efficiently and at a faster rate in serum-free media than in the standard 10 percent serum media.

\section{The difference between proliferation and viability}

Cell proliferation and viability are important parameters for the biological study of MSN material. Cell proliferation is defined as the cellular growth rate or is a quantified value for the daughter cell population. ${ }^{34}$ Cell viability is a quantification of the number of live cells and is usually expressed as a percentage of the control. ${ }^{35,36}$ Viability assays are important when initially seeding the cells onto a plate and to estimate the cytotoxicity of nanoparticles. For example, by measuring the viability, we can determine the cell density needed to be seeded in the plate to form a monolayer for further experiments at a desired time. We can gain information on the cytotoxicity of nanoparticles or the release efficiency of MSN based-anticancer drug delivery systems. Many reagents are used to monitor or estimate the viability and proliferation of cells. For proliferation assays, changes in nucleic acid content are most commonly measured; but for viability assays, dye reagents are employed that can distinguish the cells from non-cell species and cell membrane integrity. For example, the Guava ViaCount assay employees two dyes to determine cell status. The first dye enters all cells (live and dead) and bind to intracellular DNA. The second dye enters only dead cells, live cells exclude this dye because of the presence of an intact cell membrane. As a result, dead cells, viable cells, and non-cell species are distinguished by this fluorescent dye system.

Cell viability with MSN treatments is also an interesting property to investigate. Cell viability tests are run to understand the conditions and limits that are associated with 
MSN biocompatibility. Many controls are needed to evaluate the cytotoxicity of nanoparticles vs the cytotoxicity of molecules that are carried by the nanoparticles.

\section{The purpose of the trypan blue}

Trypan blue is a stain used to quantify live cells by labeling dead cells exclusively. Because live cells have an intact cell membrane, trypan blue cannot penetrate the cell membrane of live cells and enter the cytoplasm. In a dead cell, trypan blue passes through the porous cell membrane and enters the cytoplasm. Under light microscopy analysis, only dead cells have a blue color. Trypan blue is also used to eliminate false positives

from occurring during cell counting by flow cytometry. ${ }^{32,37,38}$ Fluorescein labeled MSN can be either internalized by cells or they can physically adsorb to the exterior of the cell membrane. When these two events occur, it is often difficult to distinguish between them by flow cytometry. By adding trypan blue to the solution, the extracellular FITC-MSN material is quenched, excluding them from the quantification. Only live cells that have internalized the FITC-MSN report a positive result. Trypan blue cannot penetrate the membrane of live cells, it will quench all the fluorescence from the physically adsorbed MSNs on cell membrane. Thus, we can assure the fluorescence detected by flow cytometry is from the cells with internalized fluorescent MSN or cell auto fluorescence. Trypan blue solution used is $0.4 \%(\mathrm{w} / \mathrm{w})$.

\section{Fluorescently labeling MSN (covalently) for endocytosis experiments}

The endocytic behavior of MSN material has drawn a considerable amount of attention in recent years. The endocytosis efficiency is commonly determined by measuring the percentage of cells displaying fluorescence above the intensity of cell autofluorescence. Generally, MSN materials are covalently labeled with a fluorescent dye, 
fluorescein isothiocyanate (FITC) is the amine reactive derivative of fluorescein commonly the fluorophore employed. For the synthesis of FITC labeled MSNs, FITC is reacted with a primary amino group derivatized silane coupling reagent (for example: aminopropyl trialkoxysilane coupling reagent).

For a standard synthesis, $10 \mathrm{mg}$ of aminopropyl trimethoxysilane (APTMS) reagent is mixed with FITC for $2 \mathrm{~h}$ in anhydrous DMSO or DMF followed by a grafting step with pristine MSN material. The FITC forms a covalent bond with the amino group of APTMS. As a result, FITC will be well distributed on silica framework. Once FITC labeled MSNs are internalized by cells they display a green fluorescence stronger than cell autofluorescence. We can determine the endocytic efficiency of MSNs by cells and monitor the cellular dynamic distribution of FITC doped MSN by measure the percent of fluorescent cells.

\section{The use of confocal fluorescence microscopy or traditional fluorescence microscopy}

Fluorescence is an important contrasting method in microscopy. Nanoparticles can be visualized when labeled with a fluorophore. Both the confocal fluorescence microscopy and the traditional fluorescence microscopy can be used to study the cell interaction with fluorescent MSN. They use fluorescence to generate the image for the cells with endocytosed fluorescent MSN. Although traditional fluorescence microscopy can identify if the cells are associated with fluorescent MSN, we cannot distinguish the physically adsorbed MSN from the internalized MSN for cells. Confocal microscopy can restrict the depth of field. Confocal microscopy eliminates most out of focus light to increase the contrast and resolution for images. Only the fluorescence very close to the focal plane is detected. Furthermore, confocal microscopy can do z-axis scanning to obtain multi- 
scanning image for one cell at different depths. The purpose to do z-axis scanning is to determine if MSN materials are truly associated with cells. By comparing the image obtained from the different cell depths, we can conclude the location of MSN materials, either just physically adsorbed on cell membrane or endocytosed into the cytoplasm. The cells are seeded in prewashed cover slips $\left(22 \mathrm{~mm}^{2}\right)$ and placed in the wells of 6-well plates at a concentration of $10^{5}$ cells $\mathrm{mL}^{-1}$ for $30 \mathrm{~h}$. After $30 \mathrm{~h}$ incubation, the cell media was replaced with MSN suspension and incubated for an additional $12 \mathrm{~h}$. After the removal of the MSN suspension, the cells are washed with PBS buffer three times and stained with $57.0 \mathrm{mM}$ nucleus dye for $30 \mathrm{~min}$. These coverslips were removed from plates and fixed to glass slides with liquid adhesive.

To clarify the interaction between cells and MSN, the issues discussed above are essential for the study of cellular behavior of MSN need to be well controlled.

Conclusions

The detailed methods and studies described in this chapter outline procedures for the synthesis of mesoporous silica nanoparticle (MSN) materials, loading the pores and external surface with various drug molecules, neurotransmitters, macromolecules and genomic material. We also outlined procedures to utilize these delivery devices to eukaryote and plant cells. Finally, several factors are identified and reported that scientists need to be aware of when researching MSN-based delivery devices. Identifying new strategies for releasing substances from the pores and surface of MSN materials will dictate the continued success of MSN based delivery systems. In addition, new functional groups such as magnetic nanoparticles and surface bound polymers may lead to the new development of novel MSN-based delivery devices. 


\section{Reference}

(1) Amar-Yuli, I.; Aserin, A.; Garti, N. Bioactive Proteins and Peptides as Functional Foods and Nutraceuticals 2010, 359.

(2) Fredenberg, S.; Wahlgren, M.; Reslow, M.; Axelsson, A. Int. J. Pharm. 2011, 415, 34.

(3) Jiang, X.; Cheng, Y.-S.; Smyth, H. D. C. J. Nanomater. 2011, 198792.

(4) Liversidge, G. Drug Development \& Delivery 2011, 11, 42.

(5) Duzgunes, N.; Simoes, S.; Slepushkin, V.; Pretzer, E.; Flasher, D.; Salem, I. I.; Steffan, G.; Konopka, K.; Pedroso de Lima, M. C. Methods in Enzymology 2005, 391,351 .

Table 1 . The property and abbreviation of MSN materials

(6) Liechty, W. B.; Kryscio, D. R.; Slaughter, B. V.; Peppas, N. A. Annual Review of Chemical and Biomolecular Engineering 2010, 1, 149.

(7) Paleos, C. M.; Tsiourvas, D.; Sideratou, Z.; Tziveleka, L.-A. Expert Opin. Drug Del.2010, 7, 1387.

(8) Salem, I. I.; Flasher, D. L.; Duzgunes, N. Methods in Enzymology 2005, 391, 261.

(9) Trewyn, B. G.; Giri, S.; Slowing, I. I.; Lin, V. S. Y. Chem. Commun. (Cambridge, United Kingdom) 2007, 3236.

(10) Ambrogio, M. W.; Thomas, C. R.; Zhao, Y.-L.; Zink, J. I.; Stoddart, J. F. Acc. Chem.Res., 2011, 44, 903.

(11) He, Q.; Shi, J. J. Mater. Chem. 2011, 21, 5845.

(12) Lee, J. E.; Lee, N.; Kim, T.; Kim, J.; Hyeon, T. Acc. Chem. Res. 2011, 44, 893. 
(13) Popat, A.; Hartono, S. B.; Stahr, F.; Liu, J.; Qiao, S. Z.; Lu, G. Q. Nanoscale 2011, 3, 2801.

(14) Rosenholm, J. M.; Sahlgren, C.; Linden, M. Curr. Drug Targets 2011, 12, 1166.

(15) Vivero-Escoto, J. L.; Slowing, I. I.; Trewyn, B. G.; Lin, V. S. Y. Small 2010, 6, 1952.

(16) Kresge, C. T.; Leonowicz, M. E.; Roth, W. J.; Vartuli, J. C.; Beck, J. S. Nature (London, United Kingdom) 1992, 359, 710.

(17) Inagaki, S.; Fukushima, Y.; Kuroda, K. Journal of the Chemical Society, Chem. Commun. 1993, 680.

(18) Beck, J. S.; Vartuli, J. C.; Roth, W. J.; Leonowicz, M. E.; Kresge, C. T.; Schmitt, K. D.; Chu, C. T. W.; Olson, D. H.; Sheppard, E. W.; et al. J. Am. Chem. Soc. 1992, 114, 10834.

(19) Linares, N.; Serrano, E.; Rico, M.; Mariana Balu, A.; Losada, E.; Luque, R.; Garcia-Martinez, J. Chem. Commun. (Cambridge, United Kingdom) 2011, 47, 9024.

(20) Slowing, I. I.; Vivero-Escoto, J. L.; Trewyn, B. G.; Lin, V. S. Y. J. Maters Chem. 2010, 20, 7924.

(21) Zhao, Y.; Vivero-Escoto, J. L.; Slowing, I. I.; Trewyn, B. G.; Lin, V. S. Y. Expert Opin. . Drug Del. 2010, 7, 1013.

(22) Slowing, I. I.; Trewyn, B. G.; Giri, S.; Lin, V. S. Y. Adv. Funct. Mater. 2007, 17, 1225. 
(23) Lai, C.-Y.; Trewyn, B. G.; Jeftinija, D. M.; Jeftinija, K.; Xu, S.; Jeftinija, S.; Lin, V. S. Y. J. Am. Chem. Soc. 2003, 125, 4451.

(24) Giri, S.; Trewyn, B. G.; Stellmaker, M. P.; Lin, V. S. Y. Angew. Chem., Int. Ed. 2005, 44, 5038 .

(25) Mortera, R.; Vivero-Escoto, J.; Slowing, I. I.; Garrone, E.; Onida, B.; Lin, V. S. Y. Chem. Commun. (Cambridge, United Kingdom) 2009, 3219.

(26) Tsai, C.-H.; Vivero-Escoto, J. L.; Slowing, I. I.; Fang, I. J.; Trewyn, B. G.; Lin, V. S. Y. Biomaterials 2011, 32, 6234.

(27) Zhao, Y.; Trewyn, B. G.; Slowing, I. I.; Lin, V. S. Y. J. Am. Chem. Soc. 2009, 131,8398 .

(28) Shino, D.; Kataoka, K.; Koyamo, Y.; Yokoyama, M.; Okano, T.; Sakurai, Y. J. Intell. Mater. Syst. Struct. 1994, 5, 311.

(29) Zhao, D.; Feng, J.; Huo, Q.; Melosh, N.; Frederickson, G. H.; Chmelka, B. F.; Stucky, G. D. Science (Washington, D. C.) 1998, 279, 548.

(30) Slowing, I. I.; Trewyn, B. G.; Lin, V. S.-Y. J. Am. Chem. Soc. 2007, 129, 8845.

(31) Kim, T.-W.; Slowing, I. I.; Chung, P.-W.; Lin, V. S.-Y. ACS Nano 2011, 5, 360.

(32) Radu, D. R.; Lai, C.-Y.; Jeftinija, K.; Rowe, E. W.; Jeftinija, S.; Lin, V. S. Y. J. Am. Chem. Soc. 2004, 126, 13216.

(33) Torney, F.; Trewyn, B. G.; Lin, V. S. Y.; Wang, K. Nat. Nanotechnol. 2007, 2, 295.

(34) Gratzner, H. G. Science (Washington, D. C., 1883-) 1982, 218, 474.

(35) King, M. A. J. Immunol. Methods 2000, 243, 155. 
(36) Kroemer, G.; Galluzzi, L.; Vandenabeele, P.; Abrams, J.; Alnemri, E. S.; Baehrecke, E. H.; Blagosklonny, M. V.; El-Deiry, W. S.; Golstein, P.; Green, D. R.; Hengartner, M.; Knight, R. A.; Kumar, S.; Lipton, S. A.; Malorni, W.; Nunez, G.; Peter, M. E.; Tschopp, J.; Yuan, J.; Piacentini, M.; Zhivotovsky, B.; Melino, G. Cell Death Differ. 2009, 16, 3.

(37) Slowing, I.; Trewyn, B. G.; Lin, V. S. Y. J. Am. Chem. Soc. 2006, 128, 14792.

(38) Trewyn, B. G.; Nieweg, J. A.; Zhao, Y.; Lin, V. S. Y. Chem. Eng. J. (Amsterdam, Neth.) 2008, 137, 23. 


\title{
CHAPTER 2. LIGAND CONFORMATION DICTATES MEMBRANE AND ENDOSOMAL TRAFFICKING OF ARGININE-GLYCINE-ASPARTATE (RGD)- FUNCTIONALIZED MESOPOROUS SILICA NANOPARTICLES
}

Modified from a paper published in Chemistry - A European Journal 2012

I-Ju Fang, Igor I. Slowing, Chia-Wen Wu, Victor S.-Y. Lin, and Brian G. Trewyn

\begin{abstract}
:
Recent breakthrough research on mesoporous silica nanoparticle (MSN) materials have illustrated their significant potential in biological applications due to their excellent drug delivery and endocytotic behavior. We set out to determine if MSN, covalently functionalized with conformation specific bioactive molecules (either linear or cyclic RGD ligands), behave towards mammalian cells in a similar manner as the free ligands. We discovered that RGD immobilized on the MSN surface did not influence the integrity of the porous matrix and improved the endocytosis efficiency of the MSN materials. Through competition experiments with free RGD ligands, we also discovered a conformation specific ligand:integrin association. The interaction between RGD immobilized on the MSN surface and integrins plays an important role in endosome trafficking, specifically dictating the kinetics of endosomal escape. Thus, covalent functionalization of biomolecules on MSN assists in the design of a system for controlling the interface with cancer cells.
\end{abstract}




\section{Introduction}

The unique pore matrix structure and surface chemistry of mesoporous silica nanoparticle (MSN) materials have given rise to a number of controlled release systems for various drug molecules. ${ }^{[1]}$ An important aspect for the successful administration of these MSN-based delivery systems is an understanding of the cellular internalization and membrane trafficking processes. Only after understanding these processes will it be possible to control them. Along this direction, both the surface chemistry and morphology of the MSN have received a significant amount of interest, especially with regards to the kinetics and efficiency of cellular internalization. ${ }^{[2]}$

An advantage of MSN materials that has been exploited recently is the surface can be functionalized through relatively straightforward chemistry to attach various molecules that uniquely effect internalization. ${ }^{[2 a, 3]}$ However, for MSN-based drug delivery investigations it is very important to understand the intracellular trafficking activities. The membrane trafficking and endosomal escape of arginine-glycine-aspartatefunctionalized mesoporous silica nanoparticles (RGD-MSN) with different RGD ligand conformations is investigated in this study. We, and others, have utilized the large surface area, multifunctionality, and low cytotoxicity of MSN as advanced tools in biomedical research and have demonstrated their potential in intracellular drug/gene delivery, bioimaging, and photodynamic therapy. ${ }^{[4]}$ In order to enhance the efficiency of the MSN in these biomedical applications, the mechanism of endocytosis needs to be examined. We have previously reported that the endocytosis of MSN by mammalian cells could be mediated by different functionalities on the external surface of the MSN and the targeting 
of specific cell surface receptors has had some recent accomplishments with ligated

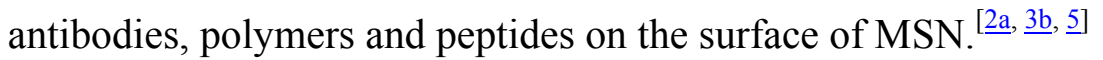

We set out to determine if MSN, covalently functionalized with conformation specific bioactive molecules, behave toward mammalian cells in a similar manner as the free moiety. Integrins, heterodimeric transmembrane proteins, are cell surface receptors that mediate attachment of different biomolecules from the extracellular matrix (ECM) or other cells to the intracellular cytoskeleton. Many extracellular matrix proteins have a common short amino acid sequence that is recognized by the integrin for binding. One common tripeptide sequence, arginine-glycine-aspartate (RGD), has an affinity in the $\mu \mathrm{M}$ range for some integrins. ${ }^{[6]}$ Researchers are interested in exploiting the interaction between the ECM and integrins because of the crucial role it has in cancer metastasis and tumor invasion. ${ }^{[7]}$ Herein, we functionalized the external surface of MSN with short RGD peptide sequences in an effort to investigate if RGD-MSN is endocytosed through an integrin associated pathway, and if the uptake efficiency of RGD-MSN is RGD ligand conformation dependant. The uptake efficiency and the endocytic pathway of RGDconjugated MSN are also studied and reported.

\section{Experimental Section}

Fluorescein isothiocyanate isomer I, methyl $\beta$-cyclodextrin, sucrose, Nhydroxysuccinimide (NHS) and $N$-cetyltrimethylammonium bromide were purchased from Sigma-Aldrich. Tetraethyl orthosilicate, 3-aminopropyltrimethoxysilane, 3isocyanate propyltrimethoxysilane were purchased from Gelest. Cyclo-RGDFK was purchased from Peptides International. $\mathrm{K}_{7}$ RGD was purchased from EZBiolab. 1-ethyl-3- 
(3-dimethyl aminopropyl) carbodiimide (EDC) was purchased from Fluka. All chemicals were used as received.

\section{Preparation of RGD-MSN:}

1a. Synthesis of FITC-MSN:

The FITC labeled MSN materials were synthesized by co-condensation method. First,

fluorescein isothiocyanate (FITC, $12 \quad \mathrm{mg}$ ) was stirred with 3aminopropyltrimethoxysilane (APTMS, $0.2 \mathrm{~mL}$ ) in $1.0 \mathrm{~mL}$ methanol for $2 \mathrm{~h}$ at room temperature. $N$-Cetyltrimethylammonium bromide (CTAB, $1.00 \mathrm{~g}, 2.74 \mathrm{mmol})$ was dissolved in $480 \mathrm{~mL}$ of nanopure water. Sodium hydroxide solution $(2.00 \mathrm{M}, 3.50 \mathrm{~mL})$ was introduced to the $\mathrm{CTAB}$ solution and the temperature of the mixture was set to $353 \mathrm{~K}$. Tetraethoxysilane (TEOS, $5.00 \mathrm{~mL}, 22.4 \mathrm{mmol}$ ) was added dropwise by syringe pump to the surfactant solution at a rate $30 \mathrm{ml} \mathrm{h}^{-1}$ under vigorous stirring. And then FITCAPTMS/methanol solution was introduced quickly to the MSN solution under stirring. The mixture was allowed to react for $2 \mathrm{~h}$ to give rise to a yellow precipitate. The solid materials were dried under high vacuum to yield the FITC-MSN.

1b. Synthesis of CA-MSN:

The FITC-MSN is further functionalized with 3-isocyanate propyltrimethoxysilane through the grafting method in order to create the carbamic acid functional group on the external surface of MSN. FITC-MSN ( $1 \mathrm{~g}$ ) was refluxed in the $80 \mathrm{ml}$ of anhydrous toluene with 3-isocyanate-propyltrimethoxysilane $(0.25 \mathrm{~mL})$ at $110{ }^{\circ} \mathrm{C}$, followed by 
washing with deionized water and methanol and dried under high vacuum to yield the assynthesized carbamic acid functionalized MSN (CA-MSN). To remove the surfactant template (CTAB), $1.0 \mathrm{~g}$ of the CA-MSN was refluxed for $6 \mathrm{~h}$ in a solution of $1.00 \mathrm{~mL}$ of

$\mathrm{HCl}(37.4 \%)$ in $100 \mathrm{~mL}$ methanol at $333 \mathrm{~K}$. The resulting material was filtered, extensively washed with deionized water and methanol and dried under high vacuum.

1c. Synthesis of RGD-MSN with $0.24 \mathrm{mmol} \mathrm{g}^{-1}$ loading (with linear or cyclic conformation): $\quad$ CA-MSN has free carbamic acid residue for the peptide coupling of RGD ligand. (either $c$ RGDFK or $\mathrm{K}_{7} \mathrm{RGD}$, see Figure 1.) $50 \mathrm{mg}$ CA-MSN was activated by EDC/NHS chemistry in $10 \mathrm{mM}$ PBS buffer $(10 \mathrm{ml}, \mathrm{pH} 7.4)$ for 2 hours, and then filtrated and washed with water in order to remove all unreacted EDC and NHS. After the unreacted EDC/NHS was removed, MSN was redispersed in $10 \mathrm{mM}$ PBS buffer $(10 \mathrm{ml}$, $\mathrm{pH}$ 7.4) with the introduction of peptide (40 $\mathrm{mg} \mathrm{K} \mathrm{K}_{7} \mathrm{RGD}$ or $13 \mathrm{mg} c \mathrm{RGDFK}$ ). The MSN suspension was stirred overnight, followed by wash with water and methanol, and dried under vacuum. MSN with the immobilization of $\mathrm{K}_{7} \mathrm{RGD}$ is called linear RGD-MSN, and MSN with the immobilization of $c$ RGDFK is called cyclic RGD-MSN. ( The pKa values of amino acid of peptides are summarized in table 1.)

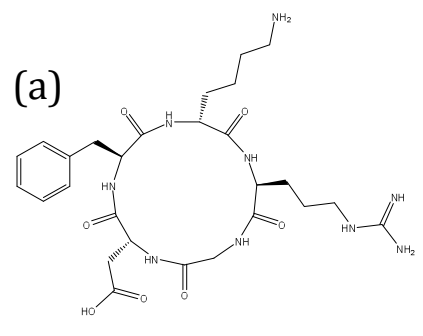

(b)

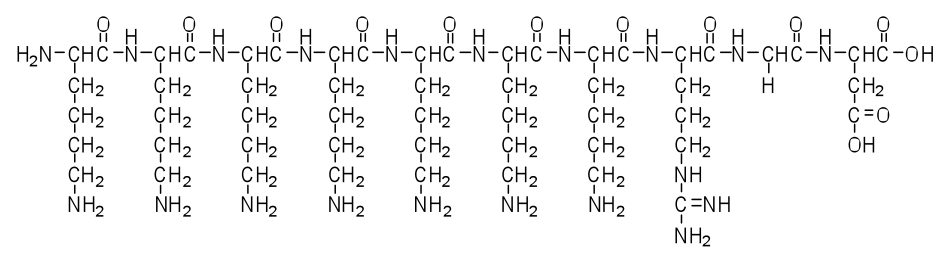

Figure 1. The structure of $c$ RGDFK (a) and $\mathrm{K}_{7} \mathrm{RGD}$ (b) 


\begin{tabular}{|c||c|c|c|c|c|}
\hline & $\mathrm{K}$ & $\mathrm{R}$ & $\mathrm{G}$ & $\mathrm{D}$ & $\mathrm{F}$ \\
\hline $\mathrm{pK}_{\mathrm{a} 1}(\mathrm{COOH})$ & 2.18 & 2.17 & 2.34 & 1.88 & 1.83 \\
\hline $\mathrm{pK}_{\mathrm{a} 2}\left(\mathrm{NH}_{3}{ }^{+}\right)$ & 8.95 & 9.04 & 9.6 & 9.6 & 9.13 \\
\hline $\begin{array}{c}\text { pKa of side } \\
\text { chain) }\end{array}$ & 10.53 & 12.48 & & 3.65 & \\
\hline $\begin{array}{c}\text { Side chain } \\
\text { group }\end{array}$ & $\left(\mathrm{CH}_{2}\right)_{4} \mathrm{NH}_{2}$ & $\left(\mathrm{CH}_{2}\right)_{3} \mathrm{NHCH}(=\mathrm{NH}) \mathrm{NH}_{2}$ & $\mathrm{H}$ & $\mathrm{CH}_{2} \mathrm{COOH}$ & $\left(\mathrm{C}_{6} \mathrm{H}_{5}\right) \mathrm{CH}_{2}$ \\
\hline
\end{tabular}

Table 1. The $\mathrm{pK}_{\mathrm{a}}$ value of amino acid

\section{Biological Experiment}

\section{Reagents and materials}

HeLa and MCF-7 cell lines were obtained from American Tissue Culture Collection (ATCC). Trypan blue solution $(0.4 \%, w / w)$ were purchased from Sigma-Aldrich. Trypsin $(1 \times, 0.25 \%)$ in $0.1 \%$ EDTA without calcium and magnesium was purchased from Fisher Scientific. SYTO ${ }^{\circledR R N A S e l e c t}{ }^{\mathrm{TM}}$ endosome marker was purchased from Invitrogen. 


\section{Cell line maintenance}

HeLa cells were maintained in D-10 media in T75 flasks using DMEM (Dulbucco's modified Eagle's medium) supplemented with 10\% equine serum, l-glutamine, penicillin, streptomycin, and gentamicin. HeLa cells were split every 2-3 days.

MCF-7 cells were maintained in D-10 media in T75 flasks using DMEM (Dulbucco's modified Eagle's medium) supplemented with 10\% bovine serum, l-glutamine, penicillin, streptomycin, gentamicin, and bovine insulin. MCF-7 cells were split every 5-6 days.

\section{Viability test}

Cell viability tests of the HeLa cells and MCF-7 cells with and without MSN were studied by Guava ViaCount assay (Guava Technologies, Inc.; Hayward, CA). Cells were seeded in six well plates with a density of $1 \times 10^{5}$ cells mL $\mathrm{mL}^{-1}$ in $3 \mathrm{~mL}$ of D-10 medium for $30 \mathrm{~h}$. After $30 \mathrm{~h}$ incubation with D-10 medium, cells were treated with the MSN suspension. Experiments were designed for all MSN materials at concentrations of 0,1 , $10,25,50$, and $100 \mu \mathrm{g} \mathrm{mL}^{-1}$ in serum-free medium. After 12 hour incubation of MSN suspension in serum-free media at $37^{\circ} \mathrm{C}$ and $5 \% \mathrm{CO}_{2}$, the cells were trypsinized, centrifuged and resuspended in $1 \mathrm{ml}$ D-10 medium. The cells in media were then counted. The cell viability was determined by the Guava ViaCount cytometry assay.

\section{Measuring the uptake efficiency of MSNs by cancer cells:}

The cells were cultured in 6-well plates for $30 \mathrm{~h}$. The cells were then treated with MSN suspension at different concentrations. Experiments were designed for all MSN

with concentrations of $0,1,5,10,25,50$, and $100 \mu \mathrm{g} \mathrm{mL} \mathrm{m}^{-1}$ in serum-free medium for 
endocytosis. The cells were incubated with the different concentrations of MSN for $12 \mathrm{~h}$ at $37{ }^{\circ} \mathrm{C}$ in $5 \% \mathrm{CO}_{2}$. After $12 \mathrm{~h}$, the cells were washed once with PBS (phosphatebuffered saline) and trypsinized. After centrifuge, the cells were redispersed in $0.4 \%$ trypan blue for 10 min to quench the fluorescence of any MSN physically adhered to the exterior surface of the cells. The MSN uptake by cancer cells was measured by flow cytometry. The cell without any MSN was set as a control to measure the cell autofluorescence. The number of cells with internalized MSN was determined by counting the cells showing fluorescence intensity higher than the cell autofluorescence.

\section{Inhibition and competition assays:}

HeLa cells or MCF-7 cells were cultured at the density of $1 \times 10^{5}$ cells mL $\mathrm{mL}^{-1}$ in 6 well plates for $30 \mathrm{~h}$ in $3 \mathrm{~mL}$ of D-10 medium. The D-10 medium was then replaced by $3 \mathrm{~mL}$ of: (a) DMEM medium for the wells used as control, (b) $450 \mathrm{mM}$ sucrose in DMEM medium for the wells used in the clathrin inhibition assay (c). $6.67 \mathrm{mM}$ methyl $ß-$ cyclodextrin in DMEM medium for the wells used in the cavoloae inhibition assay (d) $500 \mu \mathrm{M} \mathrm{K}_{7} \mathrm{RGD}$ or $250 \mu \mathrm{M} c \mathrm{RGDFK}$ in the integrin competition assay.

The cells were incubated with the inhibitors for $30 \mathrm{~min}$. The media were then replaced with $3 \mathrm{~mL}$ of MSN (40 $\mu \mathrm{g} \mathrm{mL}^{-1}$ ) in (a) DMEM medium for the wells used as control, (b) $450 \mathrm{mM}$ sucrose in DMEM medium for the wells used in the clathrin inhibition assay (c). 6.67 mM methyl ß-cyclodextrin in DMEM medium for the wells used in the caveoloae inhibition assay (d) $500 \mu \mathrm{M} \mathrm{K} \mathrm{K}_{7} \mathrm{RGD}$ or $250 \mu \mathrm{M} c$ RGDFK in the integrin competition assay. After $1 \mathrm{~h}$, the cells were washed with DMEM medium and trypsinized. After centrifugation, the cells were resuspended in $0.4 \%$ trypan blue PBS solution. The 
influence of the inhibitors on the efficiency of uptake by cancer cells was measured by flow cytometry.

\section{Fluorescence confocal microscopy measurements}

To study the endocytosis of MSN materials, fluorescence confocal microscopy was employed. Coverslips $\left(22 \mathrm{~mm}^{2}\right)$ were cleaned with surfactant Contrad 70 , nanopure water $(3 \times)$, and $100 \%$ methanol, and dried overnight and followed by polylysine coating. The polylysine coated coverslips were placed on the bottom of the wells of 6-well plates and incubated with $3.0 \mathrm{~mL}$ of standard D-10 growth media. Two samples were prepared for the confocal microscopy study. First, HeLa or MCF-7 $\left(1.0 \times 10^{5}\right.$ cells $\left.\mathrm{mL}^{-1}\right)$ were grown for $30 \mathrm{~h}$ on the coverslips. After $30 \mathrm{~h}$ cell growth, the cells were incubated with $10 \mu \mathrm{g}$ $\mathrm{mL}^{-1}$ MSN materials with endosome marker FM 4-64, and grown for an additional $37 \mathrm{~h}$.

Second, after $50 \mathrm{~h}$ of cell growth, the cells were incubated with $10 \mu \mathrm{gL}^{-1}$ MSNs with endosome marker FM 4-64, and grown for an additional $17 \mathrm{~h}$. Afterwards, the growth media was removed, the cells were washed with PBS $(2 \times)$, and the cells were then reincubated with Hoechst 33258 for 15 min to stain the cell nucleus. These coverslips were removed and fixed to glass slides with adhesive. Blue nuclei stain was observed by exciting the cells with a UV laser at $340 \mathrm{~nm}$. The green fluorescent from MSN (FITC prelabeled) particles internalized by the HeLa cells was visualized by excitation at 488 $\mathrm{nm}$ with an argon laser. The red fluorescent endosome marker was excited at $515 \mathrm{~nm}$. 


\section{Characterization}

X-ray diffraction patterns of the MSN materials were obtained in a Scintag XDS-2000 powder diffractometer using $\mathrm{Cu} \mathrm{K} \alpha$ irradiation. Surface analysis of the MSN materials was performed by nitrogen sorption isotherms in a Micromeritics Tristar 3000 sorptometer at $77 \mathrm{~K}$. The surface areas were calculated by the Brunauer-Emmett-Teller (BET). The pore size distributions were determined by the Barrett-Joyner-Halenda (BJH) method. Particle morphology was observed with a JEOL 840A scanning electron microscope with a $10 \mathrm{kV}$ acceleration voltage. The TEM study was completed on a Tecnai G2 F20 electron microscope operated at $200 \mathrm{kV}$. The $\zeta$-potential of the MSN materials was measured in a Malvern Nano HT Zetasizer in triplicate. Suspensions (100 $\left.\mu \mathrm{g} \mathrm{mL} \mathrm{m}^{-1}\right)$ of each of the materials in phosphate buffer $(10 \mathrm{mM}, \mathrm{pH} 7.4)$ were prepared.

\section{RGD content determination}

Peptide $\mathrm{K}_{7} \mathrm{RGD}$ and cyclo-RGDFK have the maxima absorption at $220 \mathrm{~nm}$. The concentrations of peptide in the suspension before and after coupling with CA-MSN after centrifuge are determined by UV measurement at $220 \mathrm{~nm}$. The density of peptide bound on CA-MSN is equal to the difference of peptide concentration in the suspension between before and after peptide coupling with CA-MSN. 


\section{Results and Discussion}

MCM-41 type mesoporous silica nanoparticle materials labeled with fluorescein isothiocyanate (FITC-MSN) were synthesized by the co-condensation method. ${ }^{[2 \mathrm{a}]}$ The FITC-MSN materials were further functionalized with 3isocyanatopropyltrimethoxysilane through a post-synthetic grafting method in order to create the carbamic acid functional groups on the external surface of MSN (CA-MSN). After grafting the carbamic acid groups, acid extraction was utilized to remove the surfactant template. The RGD ligands ( $c$ RGDFK or $\mathrm{K}_{7} \mathrm{RGD}$ ) were covalently coupled to CA-MSN through the free carbamic acid residues on the external surface of the MSN and primary amines on the peptides. The carboxylic acid groups of CA-MSN were activated by EDC/NHS chemistry and followed by the introduction of RGD ligands: $\mathrm{K}_{7} \mathrm{RGD}$ immobilized on the surface to give linear RGD-MSN, and $c$ RGDFK to give cyclic RGD-

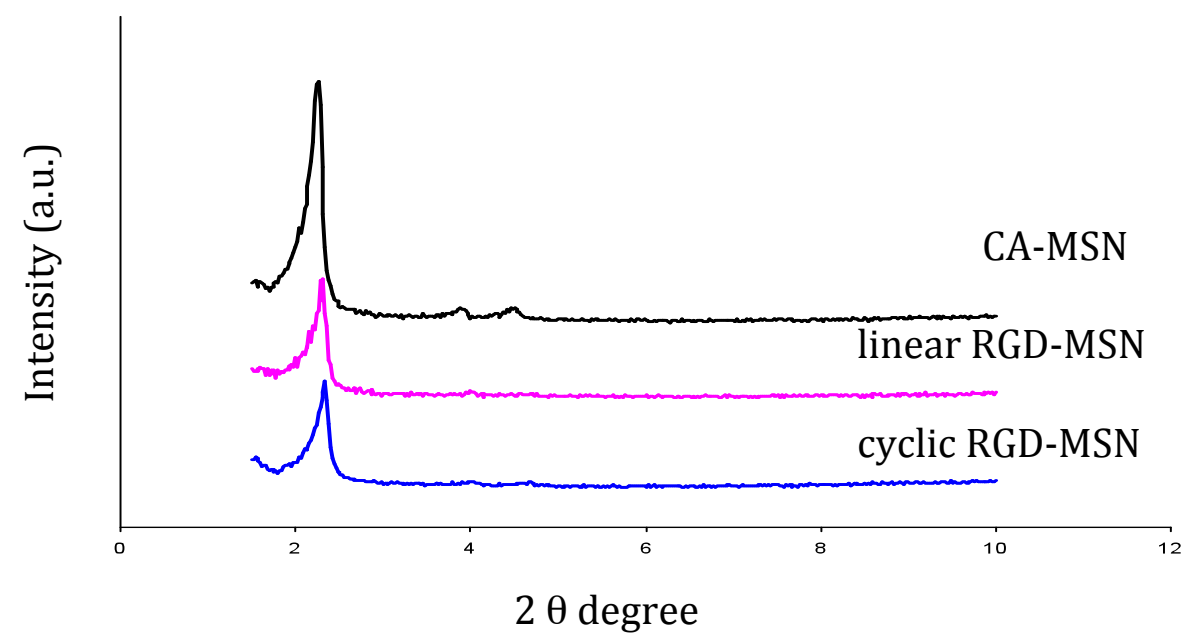

Figure 2. Low angle X-ray diffraction spectra of CA-MSN, linear RGD-MSN, and cyclic RGD-MSN. All MSNs show the typical diffraction patterns of MCM-41 tvpe with hexagonal svmmetrv. 
MSN. The different conformations of RGD ligands were chosen so we could examine the effect the 3D structure of the ligand on the surface of MSN has on the recognition of the integrin receptors on the cell surface.

(a)

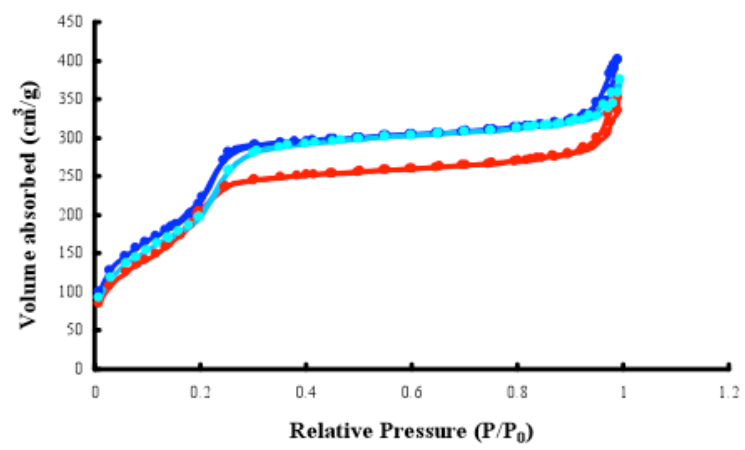

(b)

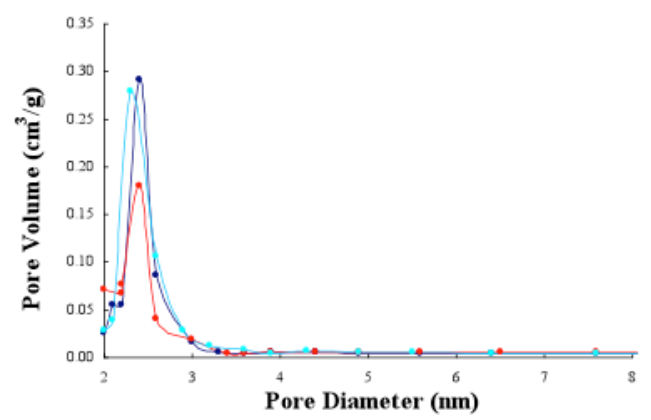

Figure 3. (a) BET nitrogen adsorption/desorption isotherms of CA-MSN (dark blue), linear RGD-MSN (red), and cyclic RGD-MSN (light blue). (b) BJH pore size distributions of CA-MSN (dark blue), linear RGD-MSN (red), and cyclic RGD-MSN (light blue). All MSNs exhibit the large surface area and the narrow pore size distribution.

Table 2. BET and BJH parameters

\begin{tabular}{|c|c|c|}
\hline Sample & Surface Area $\left(\mathrm{m}^{2} \mathrm{~g}^{-1}\right)$ & Pore Diameter $(\mathrm{nm})$ \\
\hline CA-MSN & 796 & 2.4 \\
\hline linear RGD-MSN & 785 & 2.4 \\
\hline cyclic-RGD-MSN & 737 & 2.3 \\
\hline
\end{tabular}


Powder X-ray diffraction (XRD), nitrogen sorption isotherm analysis, and scanning and transmission electron microscopy (SEM and TEM, respectively) were employed to characterize all MSN materials. A series of five functionalized MSN materials were synthesized and characterized: CA-MSN, 2-linear RGD-MSN, one with

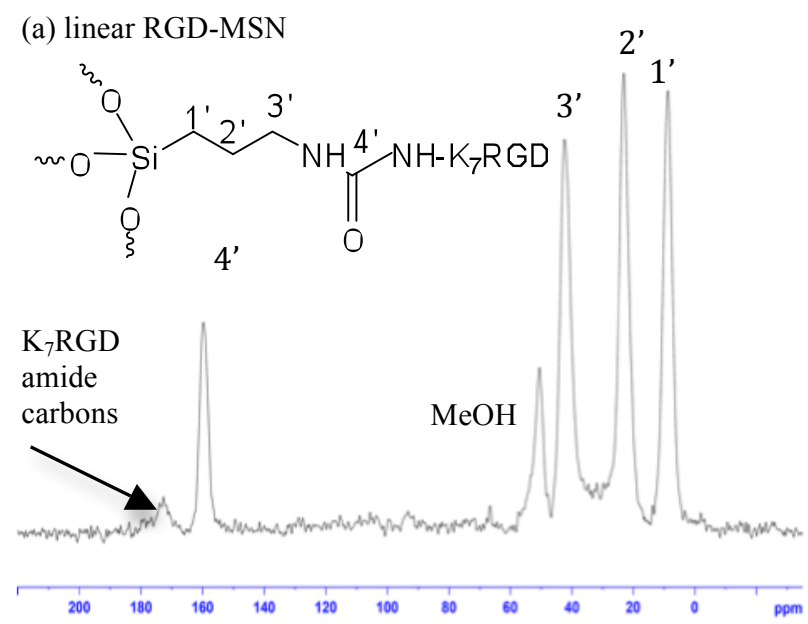

(b) cyclic RGD-MSN

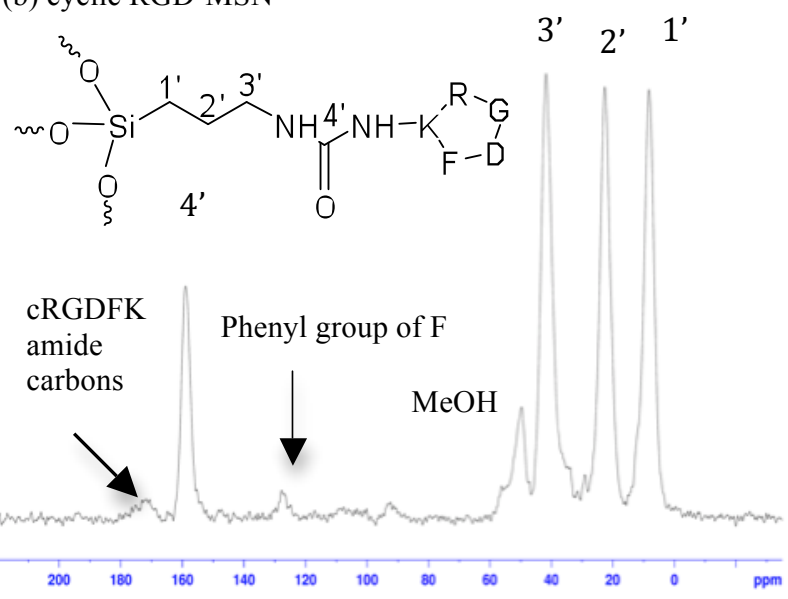

Figure $4 .{ }^{13} \mathrm{C}$ solid state CP-MAS NMR spectra of the linear RGD-MSN (a) and cyclic RGD-MSN (b). The characteristic peaks referring to peptides are shown above. 
$0.11 \mathrm{mmol} \mathrm{g}^{-1}$ and one with $0.26 \mathrm{mmol} \mathrm{g}^{-1}$ ligand loading (l-RGD-MSN-0.11 and $\mathrm{l}$ RGD-MSN-0.26, respectively); and 2-cyclic RGD-MSN, one with $0.9 \mathrm{mmol} \mathrm{g}^{-1}$ and one with $0.24 \mathrm{mmol} \mathrm{g}^{-1}$ ligand loading (c-RGD-MSN-0.09 and c-RGD-MSN-0.24, respectively); showed similarly ordered hexagonal arrangements of mesopore structure in the powder XRD spectra, proving that the post-synthetic functionalization of the MSN does not adversely affect the pore structure (see Figure 2 and Figure 3). All linear RGD-MSN and cyclic RGD-MSN materials have a spherical shape, a particle diameter ranging from $100 \mathrm{~nm}$ to $200 \mathrm{~nm}$, a 2.3-2.4 nm average pore diameter and a surface area of $737-785 \mathrm{~m}^{2} \mathrm{~g}^{-1}$ ( Table 2) as determined by electron microscopy and nitrogen sorption analyses. The RGD functionality does not influence the physical nature of CA-MSN such as the structure of the mesopores and nanoparticle morphology. The amount of carbamic acid on the MSN surface was determined by solid-state direct polarization ${ }^{29} \mathrm{Si}$ NMR measurements. The total loading of carbamic acid on the MSN surface was determined to be approximately

Table 3. Zeta potential and $\mathrm{EC}_{50}\left(\mu \mathrm{g} \mathrm{mL} \mathrm{mL}^{-1}\right)$ values of the endocytosed MSN

\begin{tabular}{ccccc}
\hline Material & $\begin{array}{c}\xi- \\
\text { potential } \\
(\mathrm{mV})\end{array}$ & $\begin{array}{c}\mathrm{EC}_{50} \\
(\mathrm{HeLa})\end{array}$ & $\begin{array}{c}\mathrm{EC}_{50} \\
(\mathrm{MCF}-7)\end{array}$ & $\begin{array}{c}\text { Ligand loading } \\
\left(\mathrm{mmol} \mathrm{g}^{-1}\right)\end{array}$ \\
\hline $\begin{array}{c}\text { CA-MSN } \\
\text { linear }\end{array}$ & -17.76 & 4.0 & 13.0 & 0 \\
$\begin{array}{c}\text { RGD-MSN } \\
\text { linear }\end{array}$ & -9.26 & 2.1 & 11.9 & 0.11 \\
$\begin{array}{c}\text { RGD-MSN } \\
\text { cyclic }\end{array}$ & -7.50 & 1.4 & 11.1 & 0.26 \\
$\begin{array}{c}\text { RGD-MSN } \\
\text { cyclic }\end{array}$ & -10.30 & 1.8 & 9.7 & 0.09 \\
RGD-MSN & -8.94 & 1.1 & 7.1 & 0.24 \\
\hline
\end{tabular}


$2.0 \mathrm{mmol} \mathrm{g}^{-1}$. The successful immobilization of RGD ligands on CA-MSN surface was confirmed by solid-state cross polarization ${ }^{13} \mathrm{C}$ NMR analysis (Fig. 4). The characteristic peaks of amide carbons of both $\mathrm{K}_{7} \mathrm{RGD}$ and $c$ RGDFK are around 172 ppm. The shift in the phenyl group of phenylalanine (F) in the $c$ RGDFK peptide is located in the range of 126 to $136 \mathrm{ppm}$. The peaks of the backbone carbons of the peptide overlap with the peaks attributed to the propyl groups of the propylcarbamic acid spacer.

The amount of RGD on the MSN surface was quantified by UV measurements, the density of RGD ligands on both linear RGD-MSN and both cyclic RGD-MSN materials are shown in Table 3.

The zeta potential values for CA-MSN, both linear RGD-MSN, and both cyclic RGDMSN materials in $10 \mathrm{mM}$ PBS buffer (pH 7.4) are also shown in Table 3. The CA-MSN had the most negative surface charge, while the cyclic and linear RGD-MSN materials were less negative by greater than $7.5 \mathrm{mV}$. This is consistent with the prediction that the coupling of $c$ RGDFK and $\mathrm{K}_{7}$ RGD with CA-MSN will result in a more positive surface because both peptides have a basic pI value (see Table 1).

In order to investigate the cell targeting characteristics of RGD-MSN, two cell lines with different types of RGD dependant integrins on the cell surface were studied (see Table 4), HeLa cells (human cervical cancer) and MCF-7 cells (human breast cancer) ${ }^{[8]}$

First, the biocompatibility of all types of MSN materials was examined by comparing cell viability with and without MSN. Cells were seeded in six well plates with a density of $1 \times 10^{5}$ cells $\mathrm{mL}^{-1}$. After $30 \mathrm{~h}$ incubation, cells were treated with MSN suspensions at the concentrations of $0,1,10,25,50$, and $100 \mu \mathrm{gL}^{-1}$. After $12 \mathrm{~h}$ incubation with MSN, 
the viable cells were quantified. From the viability test results shown on Figure 5, all MSN materials tested correspond to good biocompatibility $\left(\mathrm{LC}_{50}\right.$ greater than $100 \mu \mathrm{gmL}^{-}$ $\left.{ }^{1}\right) .{ }^{[9]}$

(a) $\mathrm{HeLa}$

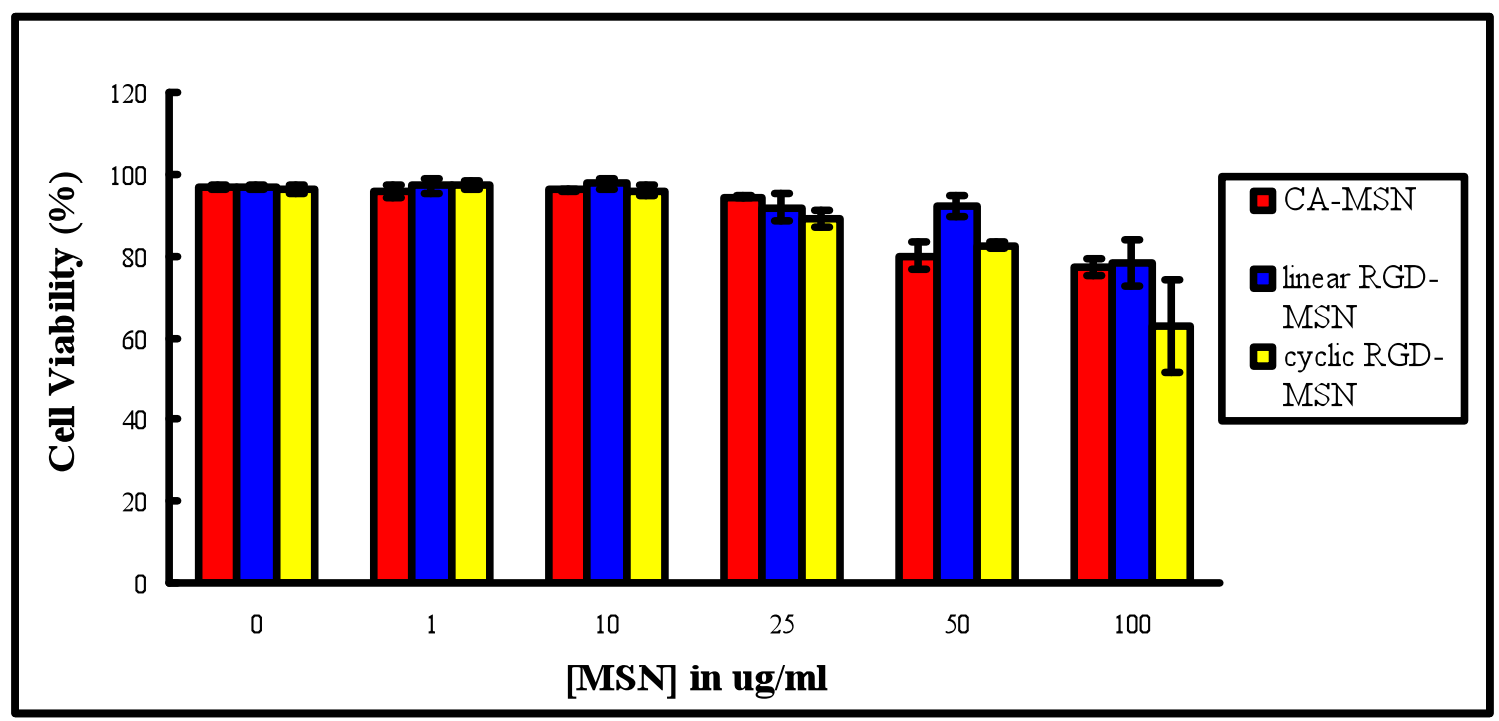

(b) $\mathrm{MCF}-7$

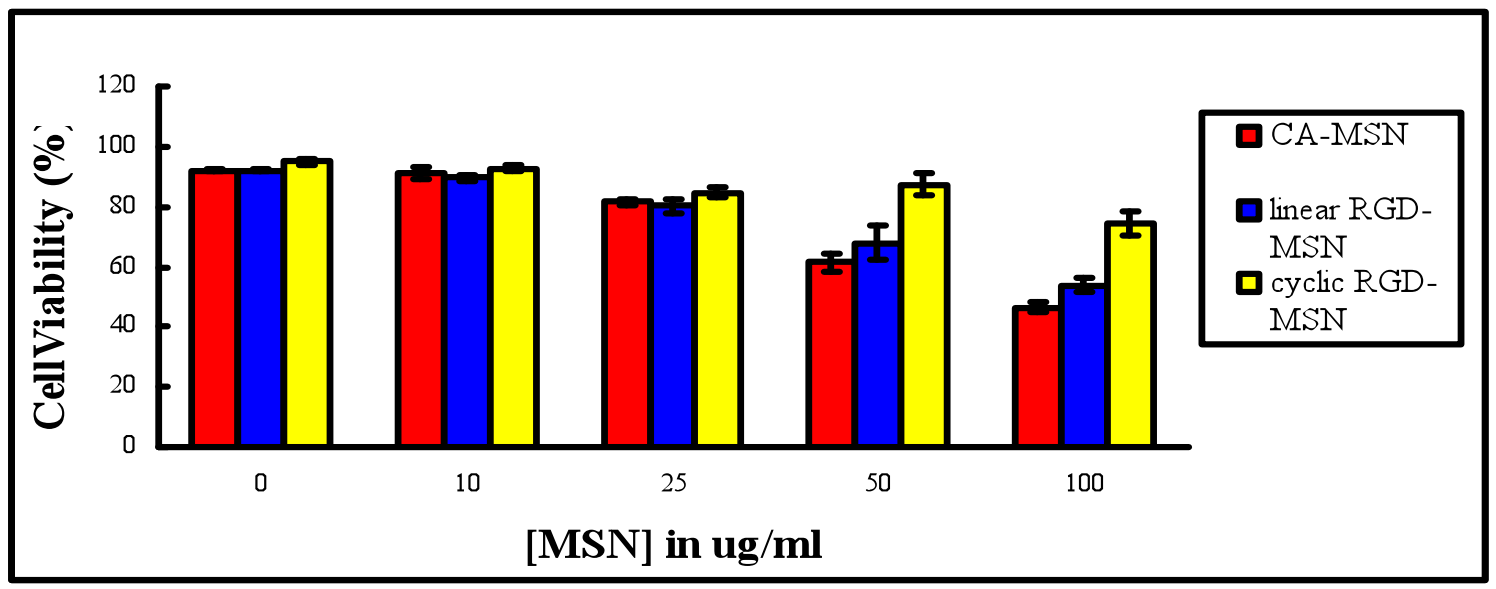

Figure 5. Cell viability data of MSN materials for Hela (a) and MCF-7 (b). 
Table 4. The integrin types of HeLa and MCF-7 cell lines. (RGD dependent integrin is in red.)

\begin{tabular}{|c||c|}
\hline Cell Type & Integrin Type \\
\hline HeLa & $a_{1} \beta_{1}, \alpha_{2} \beta_{1}, \alpha_{3} \beta_{1}$, \\
Human cervical cancer cell & and $\alpha_{6} \beta_{1}$, \\
\hline MCF-7 & $a_{2} \beta_{1}, \alpha_{V} \beta_{5}$, and $\alpha_{V} \beta_{3}$ \\
Human breast cancer cell & \\
\hline
\end{tabular}

Ref: Borrirukwanit, K. Matrix Biology 26 (2007) 291-305

To examine the uptake efficiency of the MSN by cancer cells, they were incubated with MSN at different concentrations for $12 \mathrm{~h}$ at $37{ }^{\circ} \mathrm{C}$. The HeLa and MCF-7 cells that internalized MSN were quantified by flow cytometry. The cells that were not incubated with MSN materials were used as a control to measure the cell autofluorescence. The number of cells with internalized MSN was determined by counting the cells showing fluorescence intensity higher than the cell autofluorescence. Trypan Blue was added to quench the fluorescence from extracellular MSN materials that were adsorbed on the cell surface.

The data on the uptake efficiency of MSN by the cells are shown on Figure 6 and the $\mathrm{EC}_{50}$ values of both cell lines are summarized in Table 3 . The uptake efficiency of MSN by the cells is a function of the concentration of MSN and the $\mathrm{EC}_{50}$ is defined as the effective concentration of MSN with 50\% cellular uptake and is determined directly from the curve in Figure 6. A series of RGD-MSN materials with different loading ligand densities were synthesized to investigate the relationship between endocytosis and ligand density. The uptake efficiency for l-RGD-MSN-0.26 is 2.8 

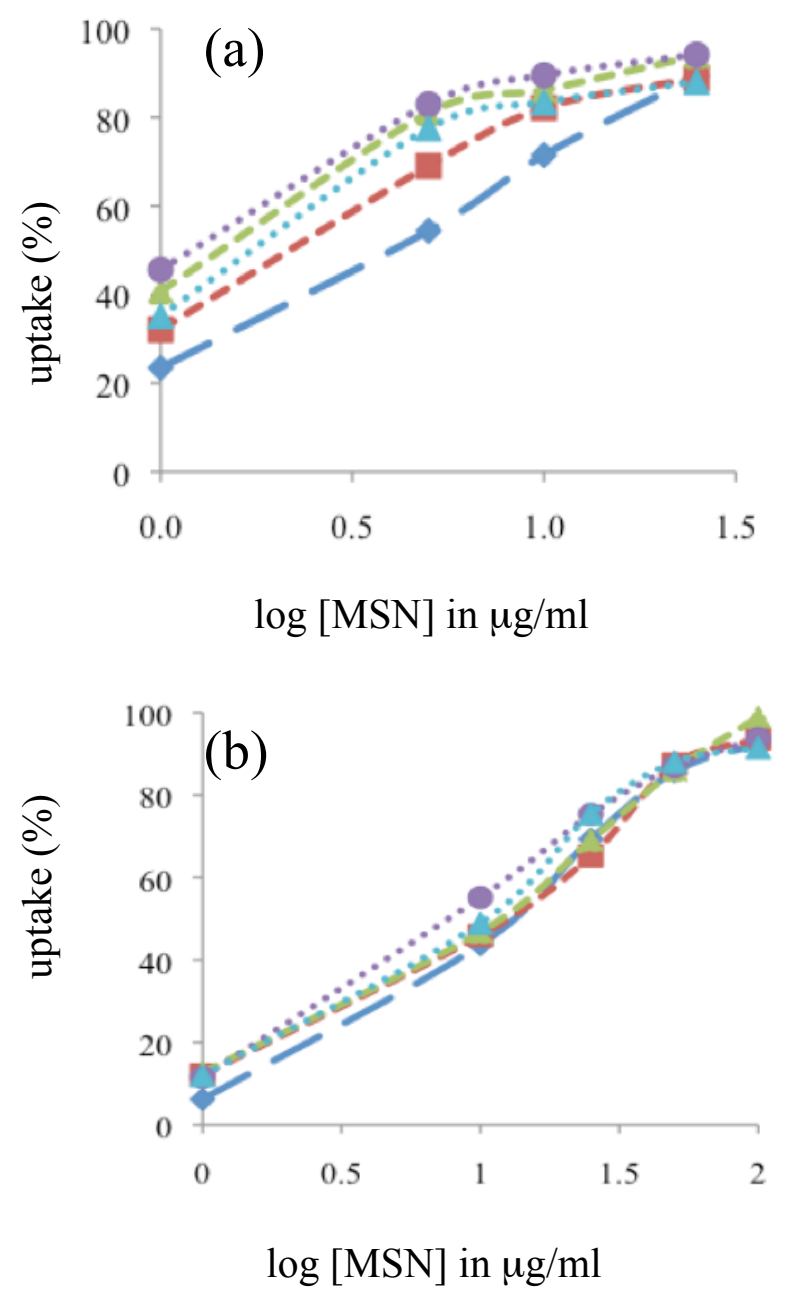

Figure 6. Uptake of the functionalized MSN by HeLa (a) and MCF-7 cells (b) (CA-MSN-dark blue, linear RGD-MSN-0.11 mmol-red, linear RGD-MSN-0.26 mmol-green, cyclic RGDMSN-0.09 mmol-light blue, and cyclic RGD-MSN-0.24 mmolpurple). The number refers to the ligand loading density.

times that of CA-MSN in HeLa and about 1.1 times that of CA-MSN in MCF-7. This demonstrates a clear role in the participation of the receptors in internalization. The $c$-RGD-MSN-0.24 has even greater uptake efficiency (3.6 times in HeLa and 1.8 times in MCF-7 over CA-MSN). In addition, the $c$-RGD-MSN-0.24 mmol is about 1.3 times greater than l-RGD-MSN-0.26 mmol for HeLa and 1.5 times greater than MCF7, see Table 3 for absolute values. When the surface ligand density was decreased by 
half, both RGD-MSN materials demonstrated lower endocytosis efficiency. Interestingly, $l$-RGD-MSN-0.26 mmol is about 1.3 times greater than $c$-RGD-MSN$0.09 \mathrm{mmol}$ in HeLa but 1.1 times less in MCF-7. The conformation and surface density of RGD ligand plays an important role on the control of cellular uptake efficiency. Thus, RGD-MSN demonstrated selectivity between two cancer cell lines.

To determine if the lysine linker contributes to the improved endocytosis efficency of linear RGD-MSN, we employed previously demonstrated procedure where trypsin cleaved lysine-containing peptides on the surface of MSN. ${ }^{[10]}$ By treating linear RGDMSN with trypsin, we determined that the lysine linker, does in fact, contribute to the enhanced endocytosis efficiency. When the linear RGD-MSN was treated with trypsin, the endocytosis efficiency increased to a higher value $\left(2.8 \mu \mathrm{g} \mathrm{mL} L^{-1}\right)$. These results indicate that both the positive lysine residues and RGD ligands contribute to the promotion of endocytosis efficiency. Trypsin lyses the lysine space linker on MSN surface resulting in the loss of the RGD moiety. Trypsinized RGD-MSN showed a decrease in endocytosis efficiency but still greater than CA-MSN (about 1.2 times greater).

The entire series of RGD-MSN materials are internalized more effectively than the control CA-MSN by both cancer cell lines tested. The RGD ligand functionality improves the accumulation of nanoparticles inside the cells. Cyclic RGD-MSN demonstrated lower $\mathrm{EC}_{50}$ values for both cell lines, indicating that the conformation of the RGD ligand on the MSN surface influenced the endocytosis efficiency. This is consistent with the previous report that the cyclic RGD has a much higher affinity for 
integrins than linear RGD. ${ }^{[1]}$ The conformation of RGD ligand on the MSN surface plays an important role in the specific recognition of receptors on cell surface.

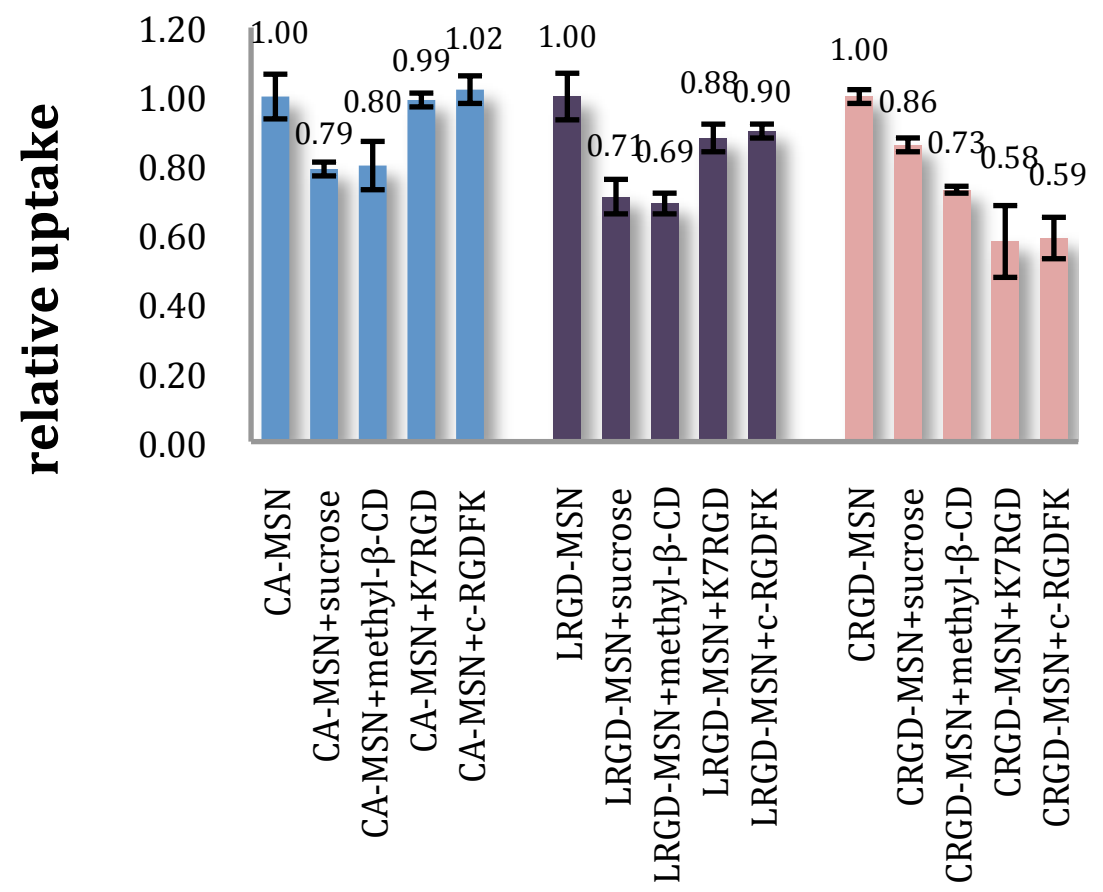

Figure 7. Relative uptake of the MSN by HeLa cells in absence and presence of a series of inhibitors: (from left to right) MSN without any inhibitor, MSN with inhibitors including $450 \mathrm{mM}$ sucrose, $6.67 \mathrm{mM}$ methyl- $\beta$-cyclodextrin, the integrin blocking reagent $500 \mu \mathrm{M} \mathrm{K} \mathrm{K}_{7} \mathrm{RGD}$, and $250 \mu \mathrm{M}$ cRGDFK. L-RGD-MSN is linear RGD-MSN, and C-RGD-MSN is cyclic RGD-MSN.

It was reported that the internalization of MSN by HeLa cells is through an endocytic process. ${ }^{[2 a]}$ It is well-known that clathrin and caveolin are intracellular proteins that regulate cellular trafficking of cargo by endocytosis. Furthermore, the integrins are internalized by cells actively undergoing endocytosis by the aid of clathrin or caveolin proteins. Thus, we investigated which endocytic pathway mediates the fate of RGD-MSN 
and how they are related to the integrins. For the inhibition assay, the clathrin inhibitor, sucrose, and caveolin inhibitor, methyl- $\beta$-cyclodextrin, were utilized. ${ }^{[12]}$ These molecules

CA-MSN

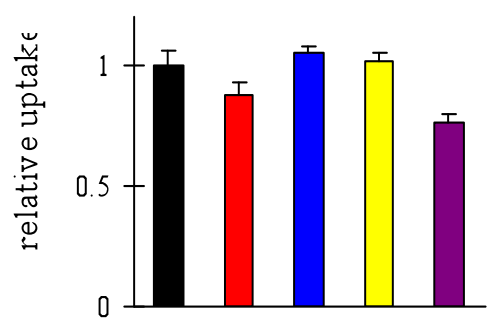

linear RGD-MSN

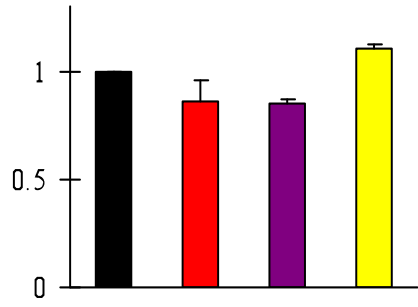

cyclic RGD-MSN

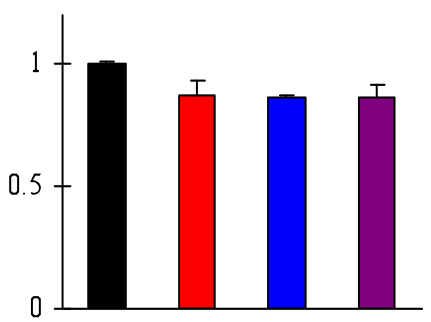

Figure 8. Uptake of the MSN materials by MCF-7 cells in absence and presence of a series of inhibitors: MSN without any inhibitor (black), MSN with inhibitors including $450 \mathrm{mM}$ sucrose (red), $6.67 \mathrm{mM}$ methyl- $\beta$-cyclodextrin (purple), the integrin blocking reagent $500 \mu \mathrm{M} \mathrm{K}_{7} \mathrm{RGD}$ (yellow), and $250 \mu \mathrm{M}$ cRGDFK (blue).

inhibit the activity of the active endocytosis proteins for a short period of time. For the competition assay, $\mathrm{K}_{7} \mathrm{RGD}$ or $c$ RGDFK was utilized as the integrin-associated blocking reagent. The free RGD peptides saturate the available binding sites of the integrin receptors on the cell membrane. The uptake of entire series of MSNs decreased with the addition of sucrose and methyl- $\beta$-cyclodextrin meaning clathrin and caveolin regulate the endocytosis of CA-MSN, linear RGD-MSN, and cyclic RGD-MSN (Figure 7).

The integrin blocking reagents do not influence the uptake of CA-MSN due to the lack of integrin/RGD interactions. The introduction of free RGD ligands caused a minimal decrease in the uptake of linear RGD-MSN. Furthermore, a significant decrease of MSN internalization was observed in the uptake of cyclic RGD-MSN in the presence of either 
free $c$ RGDFK or $\mathrm{K}_{7} \mathrm{RGD}$. The free RGD ligands with different conformation bind to integrin receptors with different affinity. ${ }^{[11]}$ Generally speaking, cyclic RGD ligands bind to intergrin receptors more strongly than linear RGD ligands because free linear RGD have many random conformations in solution, which decreases the binding strength of the integrin. ${ }^{[11]}$ Thus, the concentration of $\mathrm{K}_{7} \mathrm{RGD}$ used in the competition assay needed to be higher than that of cyclic RGD in order to achieve complete saturation of the integrin receptors. To determine the effect of free linear RGD concentration on the competition assay several different solutions were tested. At $250 \mu \mathrm{M}$, no inhibition was observed, but when the concentration was increased to $500 \mu \mathrm{M}$, the endocytosis efficiency of linear RGD-MSN was suppressed. Both linear and cyclic free RGD ligands decrease the cellular uptake of all RGD-MSN to some level, indicating that free RGD ligands and the RGD-MSN compete for binding to the integrin receptors along the same pathway.

Also, these experiments are evidence that RGD plays an important role in integrin recognition and aids in RGD-MSN endocytosis by the cells. If the binding between RGD and the integrin occurs, the endocytic pathway is dependent on the integrin association. The data shown above in Figure 3 quantifying MSN uptake is obtained from HeLa cell studies. Similar results were obtained with the MCF-7 cells were shown on Figure 8. Furthermore, those endocytosis studies and competition assays were also tested on normal cell line skin fibroblast (Figure 11-12). RGD functionality did not promote the uptake efficiency of MSN, and the endocytic pathway was not blocked by free RGDs, either linear or cyclic ligands . 
Fluorescence confocal experiments were performed to determine the location of MSN inside HeLa cells (Figure 9). FITC labeled MSN, endosome marker FM-4-64, and nuclear staining dye Hoechst 33358 emit at different fluorescence wavelengths and the locations of the MSN, endosomes, and nucleus which appear as green, red and blue colors, respectively, are observed. The overlays of all the channels gave the images shown in Figure 9. The yellow spots observed in Figures $9 \mathrm{~b}$ and $9 \mathrm{c}$ are the result of the co-localization of green (FITC-MSN) and red endosome markers. These images indicate that after cellular internalization, both the cyclic and linear RGD-MSN remain temporarily in endosomes (Figure $9 \mathrm{~b}$ and $9 \mathrm{c}$ ), but are released later to the cytoplasm as revealed by the abundant green fluorescent spots (Figure 9d and 9e).

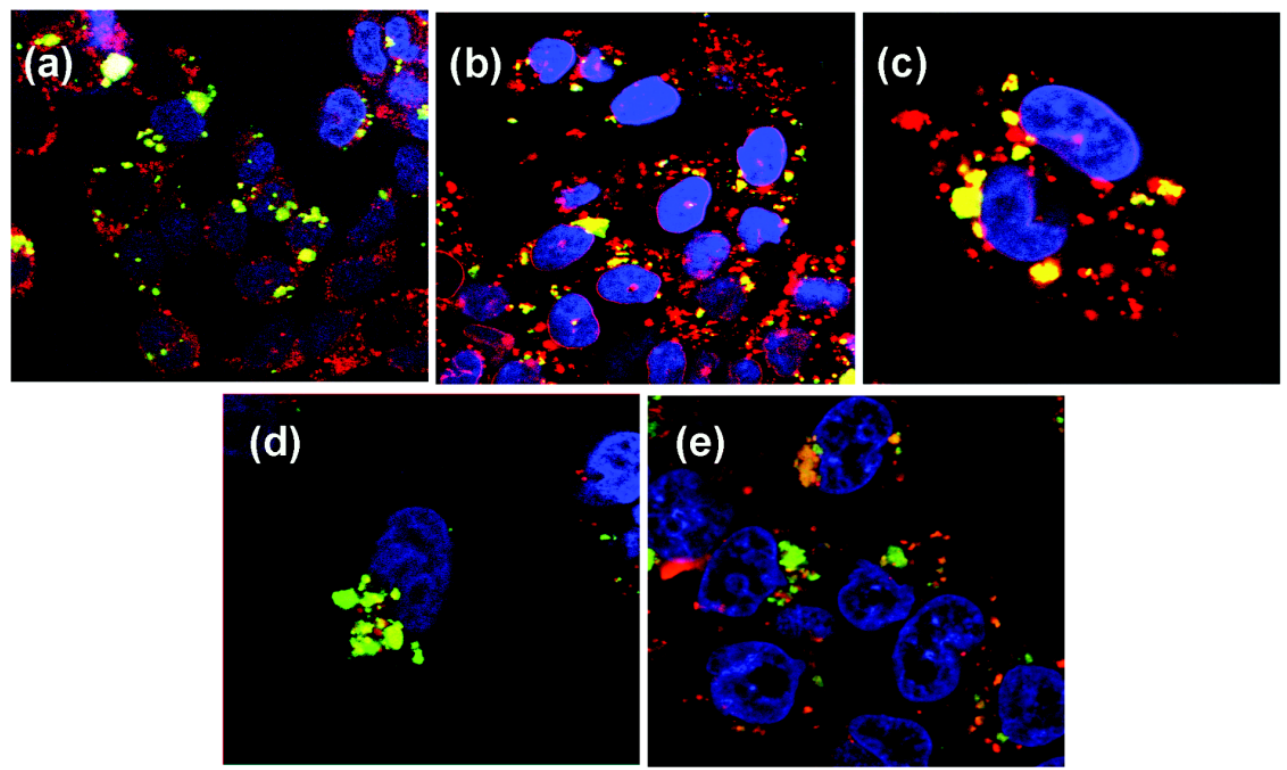

Figure 9. Fluorescence confocal micrographs of HeLa cells after a $17 \mathrm{~h}$ incubation with CA-MSN (a); with linear-RGD-MSN (b); with cyclic-RGD-MSN (c), and after a $40 \mathrm{~h}$ incubation with linear-RGD-MSN (d); with cyclic-RGD-MSN (e). Most CA-MSN escape from the endosomes within $17 \mathrm{~h}$ incubation. Linear RGD-MSN and cyclic-RGD-MSN are trapped inside the endosomes after incubating for $17 \mathrm{~h}$. After $40 \mathrm{~h}$ incubation, linearRGD-MSN and cyclic-RGD-MSN escape from the endosomes into the cytoplasm. 

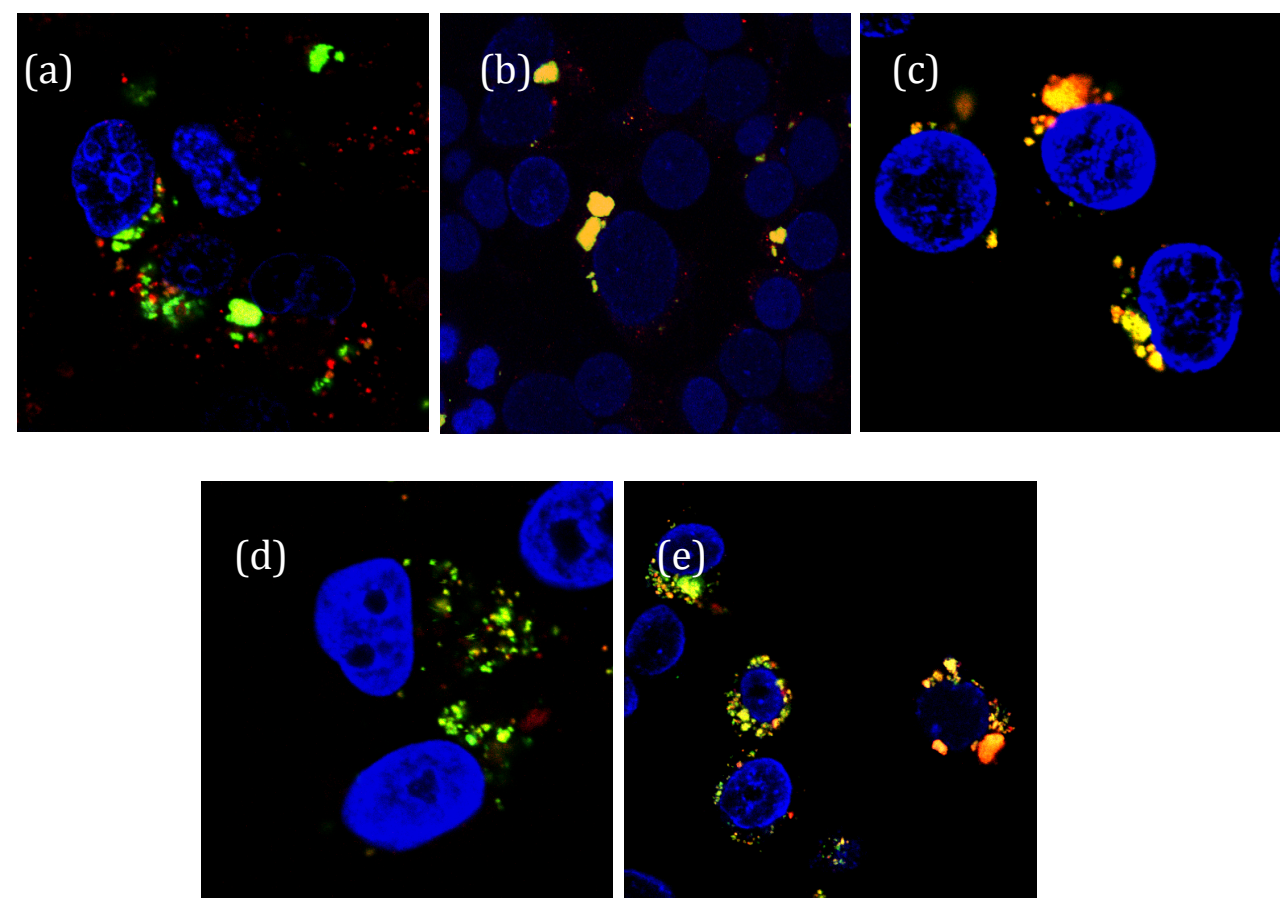

Figure 10. Fluorescence confocal micrographs of MCF-7 cells after a $17 \mathrm{hr}$ incubation with CA-MSN (a); with linear RGD-MSN (b); with cyclic-RGD-MSN (c), and after a 40 hr incubation with linear RGD-MSN (d); with cyclic-RGD-MSN (e).

Interestingly, microscopy evidence indicated that most CA-MSN escaped from endosomes much earlier than both of the RGD-MSN (Figure 9a). A possible explanation for this observation is that the RGD functionality caused RGD-MSN to remain in the endosomes for a longer period of time compared to CA-MSN because of the binding between RGD ligands and the receptor integrins, which would now be present on the inside of the endosome (Scheme 1). Integrin trafficking is the process by which integrins are endocytosed in vesicles and recycled back to the membrane. ${ }^{[7 b, 13]}$ Thus, when RGDMSN binds with integrins, the MSN/integrin complex would be transported into the endosome. Though the binding of RGD-MSN to the integrin influenced the interaction 

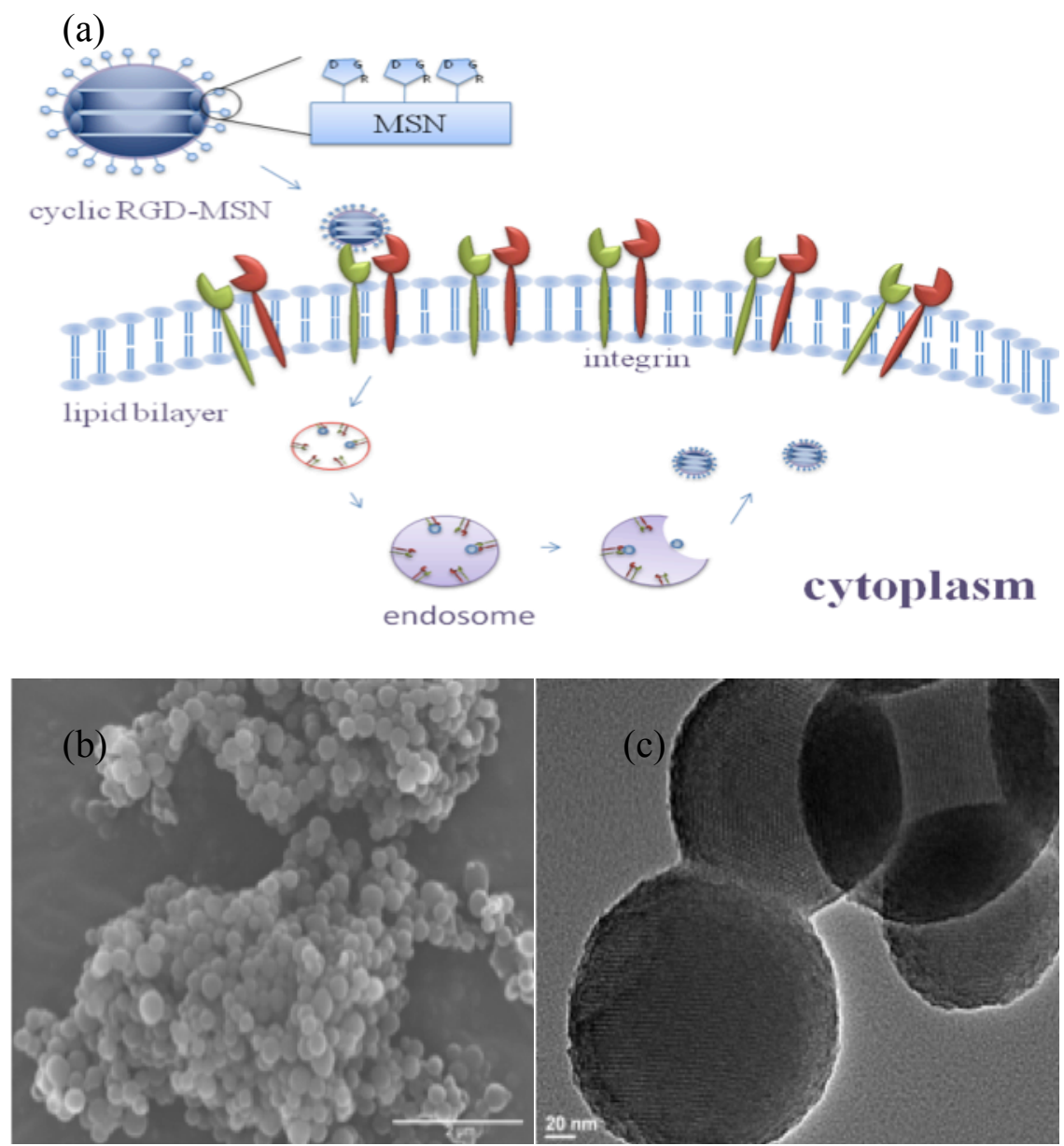

Scheme 1. The mechanism of endocytosis of cyclic-RGD-MSN (a), scanning electron micrograph (b), and transmission electron micrograph (c) of RGD-MSN. The scheme is not to scale.

between MSN and endosomes, our results indicate that they still escaped from the endosome after 40-h incubation (Figure 9d and 9e). Also, MCF-7 showed the similar behavior shown on Figure10. 


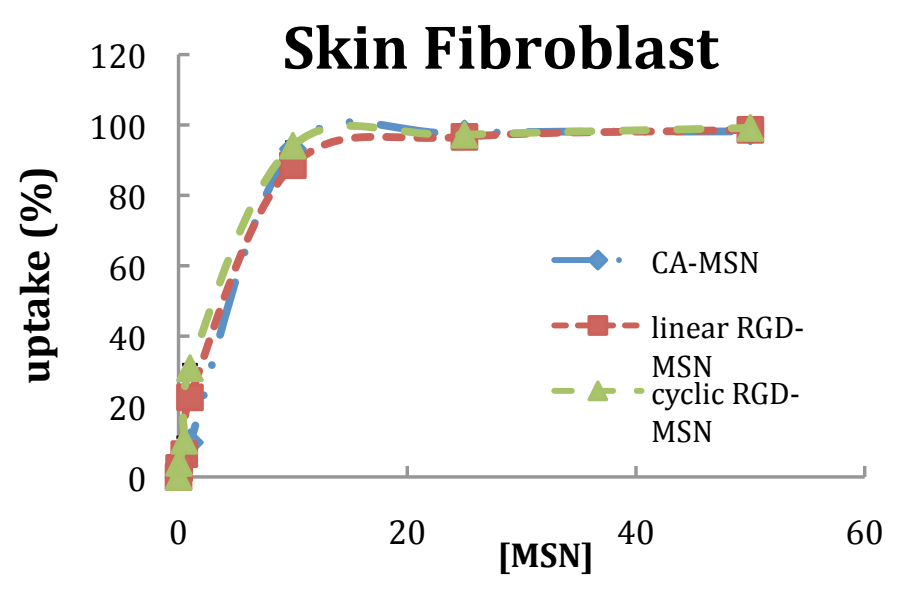

Figure 11. Cellular uptake of MSNs by skin fibroblast cells as a function of the concentration of MSN.

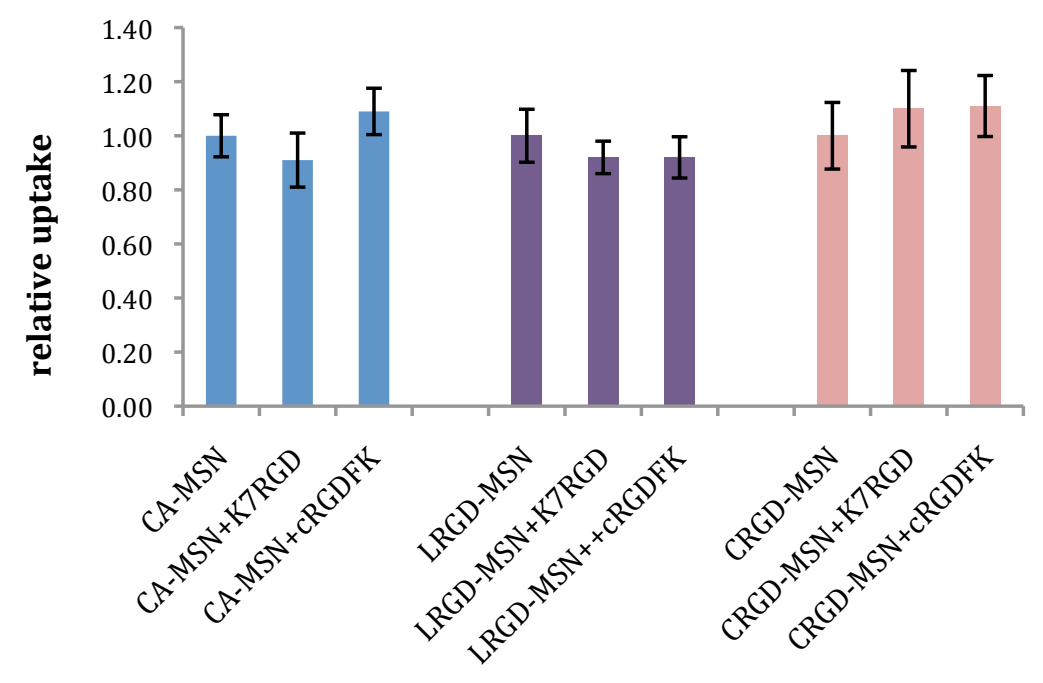

Figure 12. The competition assay with the free RGD ligands for different MSNs on skin fibroblast cell line 


\section{Conclusion}

In conclusion, we demonstrated that cyclic and linear RGD-MSN are internalized by human ovarian and breast cancer cells more effectively than CA-MSN through the integrin associated endocytotic pathway and undergo endosomal escape after 40 hours. Our results also indicate that due to the lack of highly active, specific surface bound integrins, ${ }^{[14]}$ some nontumor associated cells do not internalize RGD-MSN via an integrin associated endocytic pathway. Specifically, we demonstrated that the uptake of cyclic RGD-MSN was more efficient and greatly effected by the competition of free linear and cyclic RGD. These results indicate that the uptake efficiency of RGD-MSN is dependent upon the conformation of the RGD ligand. This supports the idea that covalent functionalization of biomolecules on MSN assists in the design of a system for controlling the interface with cancer cells.

\section{Reference}

(1) a.) K. K. Coti, M. E. Belowich, M. Liong, M. W. Ambrogio, Y. A. Lau, H. A. Khatib, J. I. Zink, N. M. Khashab, J. F. Stoddart, Nanoscale 2009, 1, 16-39; b.) I. I. Slowing, J. L. Vivero-Escoto, C.-W. Wu, V. S. Y. Lin, Adv. Drug Delivery Rev. 2008, 60, 1278-1288.

(2) a.) I. I. Slowing, B. G. Trewyn, V. S.-Y. Lin, J. Am. Chem. Soc. 2006, 128, 14792-14793; b.) B. G. Trewyn, J. A. Nieweg, Y. Zhao, V. S.-Y. Lin, Chem. Eng. J. (Netherlands) 2008, 137, 23-29.

a.) S.-H. Cheng, C.-H. Lee, M.-C. Chen, J. S. Souris, F.-G. Tseng, C.-S. Yang, C.Y. Mou, C.-T. Chen, L.-W. Lo, J. Mater. Chem. 2010, 20, 6149-6157; b.) D. P. 
Ferris, J. Lu, C. Gothard, R. Yanes, C. R. Thomas, J.-C. Olsen, J. F. Stoddart, F. Tamanoi, J. I. Zink, Small 2011, 7, 1816-1826.

(4) a.) B. G. Trewyn, S. Giri, I. I. Slowing, V. S. Y. Lin, Chem. Commun. (Cambridge, U. K.) 2007, 3236-3245; b.) J. M. Rosenholm, C. Sahlgren, M. Linden, Cur. Drug Targets 2011, 12, 1166-1186; c.) A. Popat, S. B. Hartono, F. Stahr, J. Liu, S. Z. Qiao, G. Q. Lu, Nanoscale 2011, 3, 2801-2818; d.) Q. He, J. Shi, J. Mater. Chem. 2011, 21, 5845-5855; e.) H. Ouahiba, M. Gary-Bobo, D. Brevet, M. Maynadier, S. Fontanel, L. Raehm, S. Richeter, B. Loock, P. Couleaud, C. Frochet, C. Charnay, G. Derrien, M. Smaihi, A. Sahmoune, A. Morere, P. Maillard, M. Garcia, J.-O. Durand, Int. J. Pharm. 2010, 402, 221-230.

a.) H. Wu, G. Liu, S. Zhang, J. Shi, L. Zhang, Y. Chen, F. Chen, H. Chen, J. Mater. Chem. 2011, 21, 3037-3045; b.) C. Morelli, P. Maris, D. Sisci, E. Perrotta, E. Brunelli, I. Perrotta, M. L. Panno, A. Tagarelli, C. Versace, M. F. Casula, F. Testa, S. Ando, J. B. Nagy, L. Pasqua, Nanoscale 2011, 3, 3198-3207; c.) C.-P. Tsai, C.-Y. Chen, Y. Hung, F.-H. Chang, C.-Y. Mou, J. Mater. Chem. 2009, 19, 5737-5743; dJ. M. Rosenholm, A. Meinander, E. Peuhu, R. Niemi, J. E. Eriksson, C. Sahlgren, M. Linden, ACS Nano 2009, 3, 197-206.

(6) a.)A. L. Dunehoo, M. Anderson, S. Majumdar, N. Kobayashi, C. Berkland, T. J. Siahaan, J. Pharm. Sci. 2006, 95, 1856-1872; b.) U. Hersel, C. Dahmen, H. Kessler, Biomaterials 2003, 24, 4385-4415; c.) I. Saiki, Jpn. J. Pharmacol. 1997, $75,215-242$. 
(7) a.) R. O. Hynes, Cell 1987, 48, 549-554; b.) A. G. Ramsay, J. F. Marshall, I. R. Hart, Cancer and Metastasis Rev 2007, 26, 567-578; c.) M. Shimaoka, J. Takagi, T. A. Springer, Annu. Rev. Biophys Biomol. Struct. 2002, 31, 485-516.

(8) K. Borrirukwanit, M. A. Lafleur, F. A. Mercuri, T. Blick, J. T. Price, R. Fridman, J. J. Pereira, V. Leardkamonkarn, E. W. Thompson, Matrix Biology 2007, 26, 291-305.

(9) T.-W. Kim, I. Slowing Igor, P.-W. Chung, S.-Y. Lin Victor, ACS Nano 2011, 5, $360-366$.

(10) a.) A. Schlossbauer, J. Kecht, T. Bein, Angew. Chem., Int. Ed. 2009, 48, 30923095.; b.) H. D. Singh, G. Wang, H. Uludag, L. D. Unsworth, Acta Biomater. 2010, 6, 4277-4284.

(11) a.) S. J. Bogdanowich-Knipp, S. Chakrabarti, T. D. Williams, R. K. Dillman, T. J. Siahaan, J. Pept. Res. 1999, 53, 530-541; b.) C. Frochot, S. B. Di, R. Vanderesse, M.-J. Belgy, M. Dodeller, F. Guillemin, M.-L. Viriot, M. Barberi-Heyob, Bioorg. Chem. 2007, 35, 205-220.

(12) A. I. Ivanov, Exocytosis and Endocytosis, Vol. 440, Humana Press; 1 edition 2007.

(13) F. S. E. La, F. Shi, J. Sottile, Integrin trafficking, 2008, pp. 89-107.

(14) a.) S. Liu, S. P. Robinson, D. S. Edwards, Top. Curr. Chem. 2005, 252, 193-216;

b.) P. M. Mitrasinovic, Curr. Radiopharm. 2009, 2, 214-219. 


\title{
CHAPTER 3. THE STUDY OF FUNCTIONALITY OF MAGNETIC MESOPOROUS SILICA NANOPARTICLES ON CELLULAR PROTEIN SEQUESTRATION
}

\author{
I-Ju Fang, Kapil Kandel, Igor I. Slowing, and Brian G. Trewyn*
}

\begin{abstract}
Magnetic mesoporous silica nanoparticles with the desired functionality were successfully synthesized. The MSN materials with the aminopropyl, carboxylic acid, and hydrophobic functional groups were compared along with unfunctionalized MSN to determine the effect surface chemistry has on protein sequestration. The normal healthy human umbilical vein endothelial cells (HUVECs) and human cervical cancer cells (HeLa) were treated with four types of materials to investigate the relationship between silica surface functional group and the harvested proteins from both cells. We determined that the cell types can be distinguished with the treatment of materials with the different functional groups. With varying the surface functional groups, mesoporous silica nanoparticles can be used to harvest a diversity of the proteins. Thus, mesoporous silica nanoparticles with the designed surface could identify the specific cellular process or the travel pathway of excytosed nanoparticles.
\end{abstract}

\section{Introduction}


Mesoporous silica nanoparticle (MSN) materials have been applied as vehicles in the drug delivery and chemotherapy fields. ${ }^{1}$ It is well known that MSN materials are internalized by mammalian cells through energy-dependent endocytosis pathways. Furthermore, MSN materials can carry cell membrane impermeable drug cargo into animal cells and plant cells for the purpose of drug delivery. The biological applications mentioned here are based on the advantage of endocytosis, but seldomly exocytosis. However, it was recently reported that MSN materials were selectively exocytosed from noncancerous mammalian cells and harvested cellular proteins. ${ }^{2}$ The mechanisms of protein adsorption and retention by MSN materials have been reported in several publications via electrostatic interactions or hydrogen bonding. ${ }^{3}$ Cellular proteins can be physically adsorbed on to MSN surface and extracted from the pores, recovered and analyzed by tandem-MS and electrophoresis. Identification of the harvested cellular proteins could aid in determining the dynamic distribution and the path internalized MSNs travel through the cell body. Exocytosis of porous nanomaterials opened the door for another biotechnological application, the capture and transportation of cellular proteins out of cells. By identifying of cellular protein adsorbed on MSN materials, we gain information and achieve an understanding of the endocytosis process of MSN materials in more detail. These exocytosed MSN materials could be regarded to as reporters or messengers for cellular activity. Although many exocytosis studies of various nanoparticles such as quantum dots, ${ }^{4}$ gold nanoparticles, ${ }^{5}$ carbon nanotubes, ${ }^{6}$ polymer nanoparticles, ${ }^{7}$ cationic nanoparticles ${ }^{8}$ and silica particles ${ }^{9}$ were reported, they mainly focused on the mechanism, efficiency, route of exocytoses and the exocytosis dependence on particle size. Because of the network of pores and large pore volume, only 
MSN materials can trap proteins and transport them out of cells. Thus, we attempted to study the MSN extracted proteins in more detail.

The native magnetic MSN materials were found to capture and sequester some celltrafficking proteins. Also, iron oxide hybrid silica nanoparticles $\left(\mathrm{Fe}_{3} \mathrm{O}_{4} @ \mathrm{SiO}_{2}\right)$ have recently shown to have applications in the separation of proteins and peptides. ${ }^{10}$ Because $\mathrm{Fe}_{3} \mathrm{O}_{4} @ \mathrm{SiO}_{2}$ are magnetic, an external magnetic field can be utilized for relatively easy and rapid collection of the magnetic adsorbents. In addition, the silica composite assists in the protection of the iron oxide nanoparticles from agglomeration and oxidation. Furthermore, MSN materials can be further modified by organic surface functional groups. Thus, magnetic MSN materials with the desired surface functionality have the ability to adsorb different types of cellular proteins. We understand that the interaction between proteins and the silica surface is controlled by a number of factors including pore size, protein characteristics and silica surface chemistries.

Herein, we aimed to determine what effect surface modification of MSN materials have on the adsorption of cellular proteins. A series of 2-d-hexagonally packed, high surface area, high pore volume MSN materials with unique organic surface modifiers were synthesized, characterized, and analyzed for intracellular protein uptake and retention. Three different magnetic MSN surface modifiers were used to make the surfaces positive, negative and hydrophobic. They correspond to amino, carboxylic acid, and cholic acid functionalized MSN materials, respectively (unfunctionalized MSN was used for a control). We chose these three attributes because they could potentially dictate the adsorption of proteins into the pores of the MSN materials. The hypothesis is that amine functional MSN (positively charged) will capture and retain proteins with an acidic 
pI at physiological $\mathrm{pH}$ and vise versa. Similarly, some proteins (i.e. membrane bound) are hydrophobic in nature and have a low quantity of charged amino acids on the surface.

Healthy human umbilical vein endothelial cells (HUVECs) and cancerous human cervical cancer cells (HeLa) were the cell lines chosen for this investigation. Two different cell lines were tested because each cell line has variable endocytosis and exocytosis efficiencies. The study of both normal and cancer cells can be regarded as a simple model for the diseased tissue. Both cell lines demonstrated different endocytosis and exocytosis efficiency with the native magnetic MSN materials. We hypothesized that the endocytosed MSN materials will sequester different types of intracellular proteins depending upon the surface functionality.

Large pore magnetic MSN materials were chosen in order to facilitate intracellular protein adsorption and capture. The interaction between proteins and MSN surface was dictated by controlling the pore size and surface functionality of MSN materials. Large pore MSN materials have a highly ordered rigid pore structure, large pore size and surface area to accommodate sequestered proteins. Furthermore, the large pore MSN materials are made of inert, inorganic material. Their inert inorganic nature results in resistance to microbial attack and swelling. ${ }^{11,12}$ Several publications reported that both the surface chemistry and steric conditions in the interior of MSN materials influence the extent of protein adsorption. Large pore volume and pore size can reduce the steric hindrance effect allowing for protein adsorption. The intracellular proteins sequestered by the magnetic MSN materials will be separated by SDS-PAGE (sodium dodecyl sulfate polyacrylamide gel electrophoresis) and then subjected to tandem mass-spectrometry analysis (MS/MS) to get the unique fingerprints of the proteins. In this chapter, the study 
of the surface functionality of magnetic MSN materials on intracellular protein sequestration is discussed in detail.

\section{Experimental Section}

Chemicals. All chemicals were used as received without further purification. Tetramethylorthosilicate (TMOS) and cholic acid were purchased from Sigma-Aldrich. Organic silanes, including 3-aminopropyltrimethoxysilane (APTMS) and 3(triethoxysilyl)propylsuccinic anhydride were purchased from Gelest company. The Pluronic 104 triblock copolymer, $\mathrm{PEO}_{27} \mathrm{PPO}_{61} \mathrm{PEO}_{27}$, was obtained from BASF.

\section{Synthesis of large pore MSNs:}

Large-pore MSN materials were prepared by a literature procedure first. A nonionic block copolymer Pluronic P104 (7.0 g) was dissolved in an acidic solution of water (164 g) and aqueous $\mathrm{HCl}(4 \mathrm{M}, 109 \mathrm{~g})$ and stirred at $55{ }^{\circ} \mathrm{C}$ for $1 \mathrm{~h}$. Tetramethylorthosilicate (TMOS, $10.64 \mathrm{~g}$ ) was quickly added into the solution at $55^{\circ} \mathrm{C}$. After continuous stirring for $24 \mathrm{~h}$, the reaction mixture was moved to a teflon-lined, high-pressure autoclave for further hydrothermal treatment at $150{ }^{\circ} \mathrm{C}$ for $24 \mathrm{~h}$. The product was isolated by filtration, washed with copious amounts of water and methanol, and dried at $80{ }^{\circ} \mathrm{C}$ in the air. The Pluronic P104 surfactant template was removed from MSN by calcination at $550{ }^{\circ} \mathrm{C}$ for 6 h.

\section{Synthesis of magnetic large pore $\mathrm{MSNs}\left(\mathrm{Fe}_{3} \mathrm{O}_{4}-\mathrm{MSNs}\right)$}

Native magnetic MSN materials were prepared following a literature procedure by adding a solution of iron (III) nitrate $\left(\mathrm{Fe}\left(\mathrm{NO}_{3}\right) \bullet 9 \mathrm{H}_{2} \mathrm{O}\right)$ in ethanol $(1.26 \mathrm{~g}$ in $10 \mathrm{ml})$ to large-pore MSN materials $(0.5 \mathrm{~g})$. The suspension was left to dry in the air at $30{ }^{\circ} \mathrm{C}$ with 
constant stirring. The solid was then calcined in air at a heating rate of $10{ }^{\circ} \mathrm{C} \min ^{-1}$ to $300{ }^{\circ} \mathrm{C}$. This brownish powder was denoted as $\mathrm{Fe}_{2} \mathrm{O}_{3}$-MSNs. The resulting brownish powder was reduced by calcination in a constant flow of $\mathrm{H}_{2}\left(1.67 \mathrm{~cm}^{3} \mathrm{~s}^{-1}\right)$ at $300{ }^{\circ} \mathrm{C}$ for 5 $\mathrm{h}$ to yield the resulting magnetic MSN materials. This black powder was denoted as $\mathrm{Fe}_{3} \mathrm{O}_{4}$-MSNs. Superparamagnetic iron oxide nanoparticles were in the interior of the mesopores of MSNs.

\section{Synthesis of amino-functionalized $\mathrm{Fe}_{3} \mathrm{O}_{4}-\mathrm{MSNs}\left(\mathrm{AP}-\mathrm{Fe}_{3} \mathrm{O}_{4}-\mathrm{MSNs}\right)$}

Amino-functionalized $\mathrm{Fe}_{3} \mathrm{O}_{4}$-MSNs was prepared by grafting 2 mmol APTMS (3aminopropyltrimethoxysilane) to the surface of $\mathrm{Fe}_{3} \mathrm{O}_{4}$-MSNs $(1 \mathrm{~g})$ in refluxing toluene $(100 \mathrm{~mL})$ for $24 \mathrm{~h}$. The resulting solid was separated by magnetic decantation using external neodynium magnet, washed with methanol and dried under vacuum for $24 \mathrm{~h}$.

\section{Synthesis of succinic acid functionalized $\mathrm{Fe}_{3} \mathrm{O}_{4}-\mathrm{MSNs}\left(\mathrm{SA}_{-} \mathrm{Fe}_{3} \mathrm{O}_{4}-\mathrm{MSNs}\right)$}

The surface of $\mathrm{Fe}_{3} \mathrm{O}_{4}$-MSNs $\left(\begin{array}{ll}1 & \mathrm{~g}\end{array}\right)$ was grafted with 2 mmol of 3(triethoxysilyl)propylsuccinic anhydride in refluxing toluene $(100 \mathrm{~mL})$ for $24 \mathrm{~h}$. The resulting solid was separated by magnetic decantation using external neodymium magnet, washed with methanol and dried under vacuum for $24 \mathrm{~h}$. Finally, succinic acid functionalized $\mathrm{Fe}_{3} \mathrm{O}_{4}$-MSNs was obtained by stirring the synthesized material in water overnight.

\section{Synthesis of hydrophobic cholic acid functionalized $\mathrm{Fe}_{3} \mathrm{O}_{4}-\mathrm{MSNs}\left(\mathrm{CA}-\mathrm{Fe}_{3} \mathrm{O}_{4}-\mathrm{MSNs}\right)$}

Cholic acid-functionalized $\mathrm{Fe}_{3} \mathrm{O}_{4}-\mathrm{MSN}$ were synthesized by coupling the cholic acid $(122 \mathrm{mg})$ to the amino group of amino-functionalized $\mathrm{Fe}_{3} \mathrm{O}_{4}-\mathrm{MSNs}(100 \mathrm{mg})$ through EDC chemistry. Because cholic acid is not very soluble in the dichloromethane, ethanol (1 ml) needs to be added to help the dispersion of cholic acid in the $20 \mathrm{ml}$ 
dichloromethane. The introduction of EDC will activate the cholic acid and form the intermediate that is amine reactive. Thus, an amide bond is formed between the cholic acid and amino-functionalized $\mathrm{Fe}_{3} \mathrm{O}_{4}$-MSNs. The resulting solid was washed with water and methanol and dried under the vacuum. $\mathrm{CA}-\mathrm{Fe}_{3} \mathrm{O}_{4}-\mathrm{MSNs}$ are not extreme hydrophobic materials, but have relatively more hydrophobic nature than $\mathrm{AP}-\mathrm{Fe}_{3} \mathrm{O}_{4}$ MSNs and $\mathrm{SA}-\mathrm{Fe}_{3} \mathrm{O}_{4}-\mathrm{MSNs}$.

The description for the materials used in protein sequestration experiments is summarized in Table 1. The structures of functional groups on silica surface are shown in Fig 1.

Table 1 . The property and abbreviation of MSN materials

\begin{tabular}{|c|c|c|}
\hline $\begin{array}{c}\text { Surface Property at } \mathrm{pH} \\
7.4\end{array}$ & Material & Abbreviation \\
\hline N.A. & $\mathrm{Fe}_{3} \mathrm{O}_{4}$-MSNs & $\mathrm{Fe}_{3} \mathrm{O}_{4}-\mathrm{MSNs}$ \\
\hline Positive charge & $\begin{array}{c}\text { amino-propyl -functionalized- } \mathrm{Fe}_{3} \mathrm{O}_{4}- \\
\text { MSNs }\end{array}$ & $\begin{array}{c}\mathrm{AP}-\mathrm{Fe}_{3} \mathrm{O}_{4}- \\
\mathrm{MSNS}\end{array}$ \\
\hline Negative charge & $\begin{array}{c}\text { succinic acid-functionalized- } \mathrm{Fe}_{3} \mathrm{O}_{4^{-}} \\
\text {MSNs }\end{array}$ & $\begin{array}{c}\mathrm{SA}_{-} \mathrm{Fe}_{3} \mathrm{O}_{4}^{-} \\
\mathrm{MSNs}\end{array}$ \\
\hline Hydrophobic & $\begin{array}{c}\text { cholic acid-functionalized- } \mathrm{Fe}_{3} \mathrm{O}_{4}- \\
\text { MSNs }\end{array}$ & $\begin{array}{c}\mathrm{CA}_{-} \mathrm{Fe}_{3} \mathrm{O}_{4-}^{-} \\
\mathrm{MSNs}\end{array}$ \\
\hline
\end{tabular}




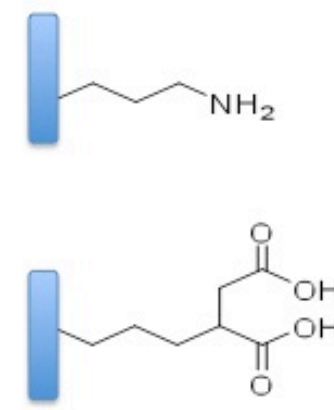

$\mathrm{AP}-\mathrm{Fe}_{3} \mathrm{O}_{4}-\mathrm{MSN}$

$\mathrm{SA}-\mathrm{Fe}_{3} \mathrm{O}_{4}-\mathrm{MSN}$

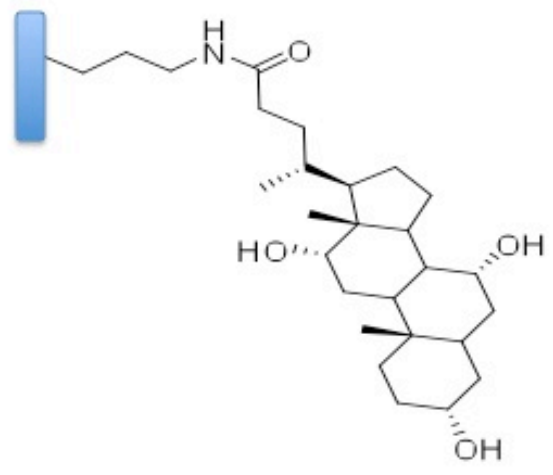

$\mathrm{CA}-\mathrm{Fe}_{3} \mathrm{O}_{4}-\mathrm{MSN}$

Figure 1. The structure of surface functional groups.

\section{Material Characterization:}

Powder X-ray diffraction (PXRD) was performed on a 2-Theta type X-ray diffractometer by Rigaku Corporation using $\mathrm{Cu}-\mathrm{K} \alpha$ radiation. The nitrogen gas sorption analysis was measured on a Tristar analyzer. A thermogravimetric analyzer 2950 manufactured by TA Instruments was used for thermogravimetric analysis (TGA) measurement of silica samples. The samples were heated from room temperature to $800{ }^{\circ} \mathrm{C}$ at ramping rate of $2{ }^{\circ} \mathrm{C} \mathrm{min}^{-1}$ in air. Scanning electron microscopy (SEM) images were taken on a Quanta 250 FEG Scanning Electron Microscope made by the FEI 
Company. Transmission electron microscopy (TEM) micrographs were recorded on a FEI Tecnai $\mathrm{G}^{2}$ F20 STEM working at $200 \mathrm{kV}$.). The $\zeta$-potential of the MSN materials was measured in a Malvern Nano HT Zetasizer in triplicate. Suspensions $\left(100 \mu \mathrm{g} \mathrm{mL} \mathrm{m}^{-1}\right)$ of each of the materials in phosphate buffer $(10 \mathrm{mM}, \mathrm{pH} 7.4)$ were prepared. Infrared spectra were obtained from NEXUS 470 FT-IR.

\section{Biological Experiment}

\section{Reagents and materials}

HeLa and HUVEC cell lines were obtained from American Tissue Culture Collection (ATCC). Trypsin $(1 \times, 0.25 \%)$ in $0.1 \%$ EDTA without calcium and magnesium was purchased from Fisher Scientific. F-12 K medium was purchased from ATCC company.

\section{Cell line maintenance}

HeLa cells were maintained in D-10 media in T75 flasks using DMEM (Dulbucco's modified Eagle's medium) supplemented with $10 \%$ equine serum, l-glutamine, penicillin, streptomycin, and gentamicin. HeLa cells were split every 2-3 days. HUVEC cells were maintained in F-12K media with the growth factor in T-75 flasks.

\section{Viability test}

Cell viability tests of the HUVEC cells with MSN were studied by Guava ViaCount assay (Guava Technologies, Inc.; Hayward, CA). After 4 hour incubation of MSN suspension in serum-free media at $37{ }^{\circ} \mathrm{C}$ and $5 \% \mathrm{CO}_{2}$, the cells were trypsinized, centrifuged and resuspended in $1 \mathrm{ml} \mathrm{D}-10$ medium. The cells in media were then counted. The cell viability was determined by the Guava ViaCount cytometry assay. 


\section{Protein-Sequestration Study:}

HUVEC were cultured in T-75 flasks in the F-12K media for several days to attain the highest cell density possible and HeLa were seeded in T-75 flasks in the D-10 media for one day to get confluency. The media was then replaced by a suspension of magnetic MSN materials in serum-free growth media $\left(50 \mu \mathrm{g} \mathrm{ml}{ }^{-1}, 50 \mathrm{ml}\right)$ and incubated at $37{ }^{\circ} \mathrm{C}$ and $5.5 \% \mathrm{CO}_{2}$ for $4 \mathrm{~h}$. The flasks were gently shaken and the supernatant was transferred to T-25 flasks with a one-inch-diameter neodymium magnet taped to the exterior of a wall. After shaking the flasks, the liquid was removed, and the magnet-immobilized particles were washed three times with sterile PBS. For protein electrophoresis, the particles were then suspended in a Tris-buffered solution $(40 \mu 1,62 \mathrm{mM}, \mathrm{pH} 6.8)$ containing 10\% glycerol, 5\% 2-mercaptoethanol, and 2\% sodium dodecylsulfate and shaken 2 days at room temperature. The suspension was then heated to $95{ }^{\circ} \mathrm{C}$ for at least 5 min and aliquots $(30 \mu l)$ were loaded into the wells of a $10-20 \%$ Tris- $\mathrm{HCl}$ polyacrylamide precast gel (10 wells, Bio-Rad Laboratories) and subjected to electrophoresis at $135 \mathrm{~V}$ for $60 \mathrm{~min}$. The resulting gels were stained with Coomassie-blue or silver staining, destained with acetic acid methanol, and photographed by the scanner. The resulting bands were cut from the gel, digested in trypsin, and subjected to MS/MS analysis. The resulting MS/MS data were used to perform a database search using Mascot software. 


\section{Results and Discussion}

(a)
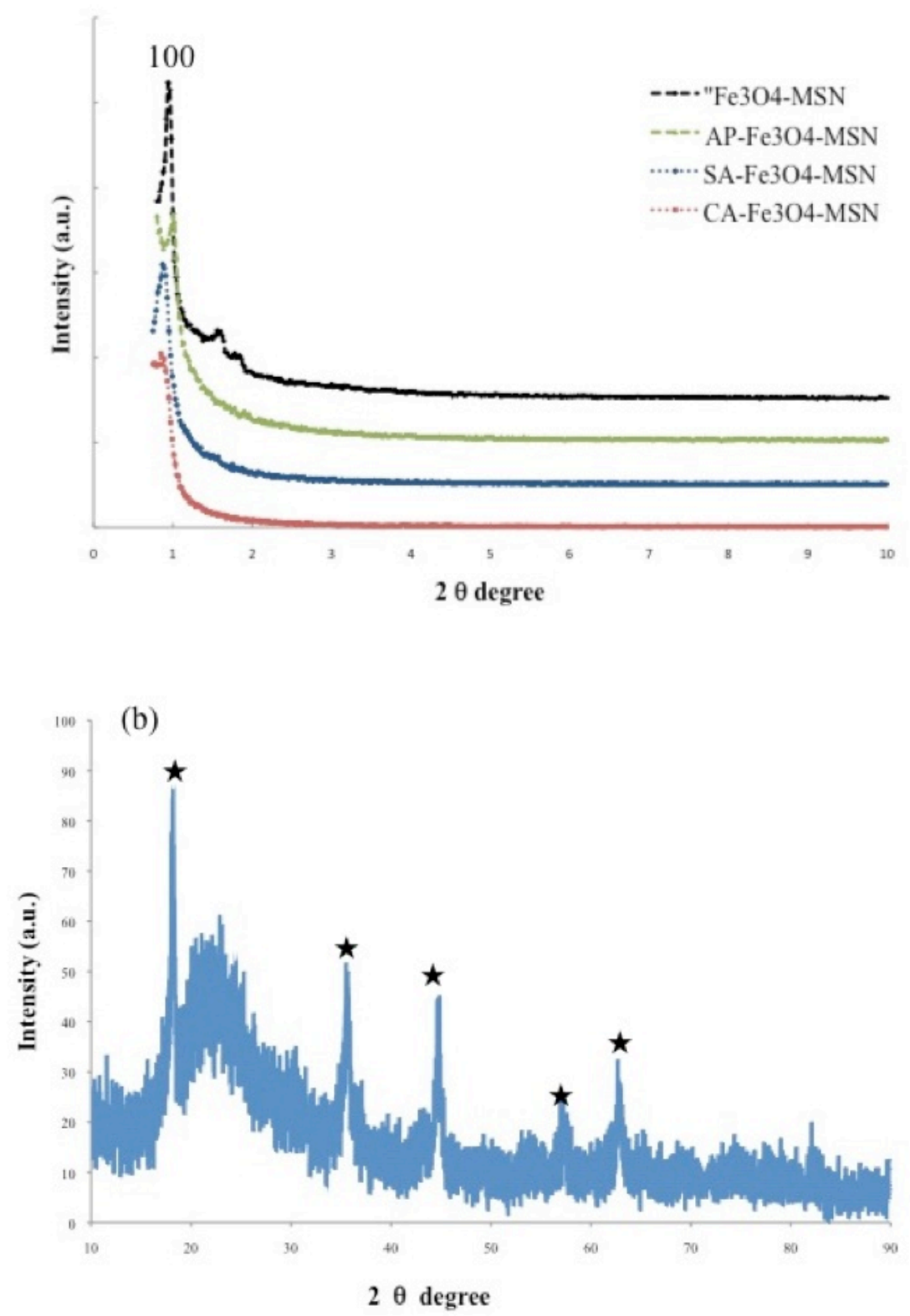

Figure 2. (a) The small angle XRD of MSN materials (a) and high angle XRD of $\mathrm{Fe}_{3} \mathrm{O}_{4}-$ MSN (b)

The mesopore arrangements of the materials are elucidated by the powder X-ray 
diffraction spectra. All the materials showed the typical (100) peak in Figure 2a, which indicate that all the materials have hexagonally ordered mesopores. At first, only $\mathrm{Fe}_{3} \mathrm{O}_{4}$ MSN also showed one sharp (100) peak and two additional fine peaks which correspond to (110) and (200) peak. The doping of iron oxide nanoparticles in the mesopores did not influence the main structure of the hexagonally arranged pores of MSN. However, both high order peaks (110 and 200) are absent because of the further organic functionality. Often, incorporation of organic functional groups will diminish the fine symmetry of mesopores. Overall, the retention of the (100) peak indicates that all the MSN materials maintained the symmetric honeycomb shaped mesopores after the addition of surface organic functional groups. The high angle XRD pattern of $\mathrm{Fe}_{3} \mathrm{O}_{4}-\mathrm{MSN}$ is shown on Figure $2 \mathrm{~b}$. The starred peaks refer to the characteristic Bragg angles of the iron oxide nanoparticles. ${ }^{10 b, 13}$

The absorption and desorption nitrogen isotherms of the MSN materials are shown on Figure 3. The existence of mesopores was confirmed again by the presence of the typical type IV hysteresis commonly associated with mesoporous materials. The coupling of organic functional groups on the native $\mathrm{Fe}_{3} \mathrm{O}_{4}-\mathrm{MSN}$ caused a decrease in the surface area and pore volumes of the MSN materials. The functional groups also have their own dimension; as a result, the diameter of the mesopores became smaller. The values of surface area and pore size for the materials were illustrated on Table 2. Even after surface immobilizing the organic functional groups all the MSN materials have a surface area and pore size large enough to accommodate many proteins. For $\mathrm{AP}-\mathrm{Fe}_{3} \mathrm{O}_{4}-\mathrm{MSN}$, the surface area is similar to the native $\mathrm{Fe}_{3} \mathrm{O}_{4}-\mathrm{MSN}$. For $\mathrm{SA}-\mathrm{Fe}_{3} \mathrm{O}_{4}-\mathrm{MSN}$, surface area of MSN material dropped significantly because of the space hindrance of succinic acid 
functional groups. $\mathrm{CA}-\mathrm{Fe}_{3} \mathrm{O}_{4}-\mathrm{MSN}$ showed the lowest surface area and pore size because the bulky cholic acid occupies a greater amount of space in the mesopores than the other two functional groups. This being said, however; all of the MSN materials still had

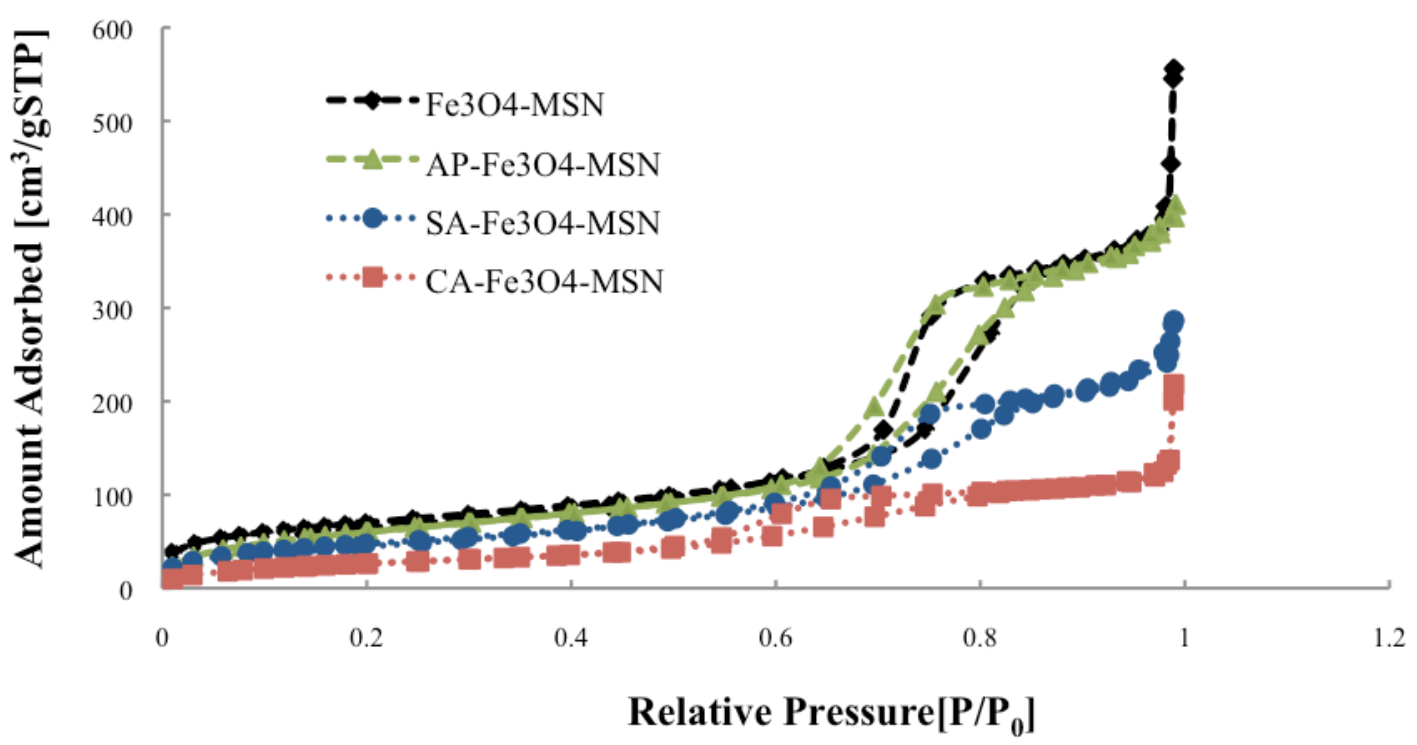

Figure 3. The sorption isotherm of iron oxide doped mesoporous silica nanoparticles. adequate space to trap the intracellular proteins.

The additional characteristic data shown in Table 3 further confirms successful surface functionalization. Organic content of the MSN materials were obtained from TGA analysis. After further organic functional group derivatization, $\mathrm{AP}-\mathrm{Fe}_{3} \mathrm{O}_{4}-\mathrm{MSN}$,

Table 2. The values of surface area and pore size of iron oxide doped mesoporous silica nanoparticles.

\begin{tabular}{|c|c|c|}
\hline Material & Surface area $\left(\mathbf{m}^{\mathbf{2}} \mathbf{g}^{-\mathbf{1}}\right)$ & Pore size $(\mathbf{n m})$ \\
\hline $\mathrm{Fe}_{3} \mathrm{O}_{4}-\mathrm{MSN}$ & 254 & 9.1 \\
\hline $\mathbf{A P}-\mathrm{Fe}_{3} \mathrm{O}_{4}-\mathrm{MSN}$ & 229 & 9.0 \\
\hline $\mathbf{S A}-\mathrm{Fe}_{3} \mathrm{O}_{4}-\mathrm{MSN}$ & 176 & 9.1 \\
\hline $\mathbf{C A}-\mathrm{Fe}_{3} \mathrm{O}_{4}-\mathrm{MSN}$ & 102 & 5.2 \\
\hline
\end{tabular}


$\mathrm{SA}-\mathrm{Fe}_{3} \mathrm{O}_{4}-\mathrm{MSN}$ and $\mathrm{CA}-\mathrm{Fe}_{3} \mathrm{O}_{4}-\mathrm{MSN}$ have adequate aminopropyl, carboxylic acid and aminopropyl cholic acid functional groups on the MSN surface, respectively. The surface charge measurements were performed in PBS at physiological $\mathrm{pH}$. The surface charge of native $\mathrm{Fe}_{3} \mathrm{O}_{4}-\mathrm{MSN}$ was negative due to a large concentration of nonprotonated silanols on the surface and the surface charge of $\mathrm{AP}-\mathrm{Fe}_{3} \mathrm{O}_{4}-\mathrm{MSN}$ was positive because of the surface bound amino groups. The coupling of cholic acid groups to the primary amines caused the surface of $\mathrm{CA}-\mathrm{Fe}_{3} \mathrm{O}_{4}-\mathrm{MSN}$ to become slightly negative. $\mathrm{SA}-\mathrm{Fe}_{3} \mathrm{O}_{4}-\mathrm{MSN}$ became more negative resulting from the grafting of propylsuccinic acid on the surface. Also, $\mathrm{SA}-\mathrm{Fe}_{3} \mathrm{O}_{4}-\mathrm{MSN}$ and $\mathrm{CA}-\mathrm{Fe}_{3} \mathrm{O}_{4}-\mathrm{MSN}$ showed the carbonyl peaks during infrared analysis that correspond to the carboxylic acid and amide bond.

Table 3. Characteristic data of the series of MSN materials including the percent by weight of the organic functional groups, the surface charge, and the wavenumber value of the infrared peaks corresponding to the surface carbonyl groups of materials.

\begin{tabular}{|c|c|c|c|}
\hline Material & $\begin{array}{c}\text { Organic content } \\
(\mathbf{\%})\end{array}$ & $\begin{array}{c}\text { Surface charge } \\
(\mathbf{m V} \mathbf{)}\end{array}$ & $\begin{array}{c}\text { Carbonyl peaks } \\
\left(\mathbf{c m}^{-\mathbf{1}} \mathbf{)}\right.\end{array}$ \\
\hline $\mathrm{Fe}_{3} \mathrm{O}_{4}-\mathrm{MSN}$ & N.A. & -18.8 & N.A. \\
\hline $\mathbf{A P}-\mathrm{Fe}_{3} \mathrm{O}_{4}-\mathrm{MSN}$ & 13.67 & +20.1 & N.A. \\
\hline $\mathbf{S A}-\mathrm{Fe}_{3} \mathrm{O}_{4}-\mathrm{MSN}$ & 13.89 & -24.8 & 1720 \\
\hline $\mathbf{C A}-\mathrm{Fe}_{3} \mathrm{O}_{4}-\mathrm{MSN}$ & 23.71 & -3.7 & 1647 \\
\hline
\end{tabular}




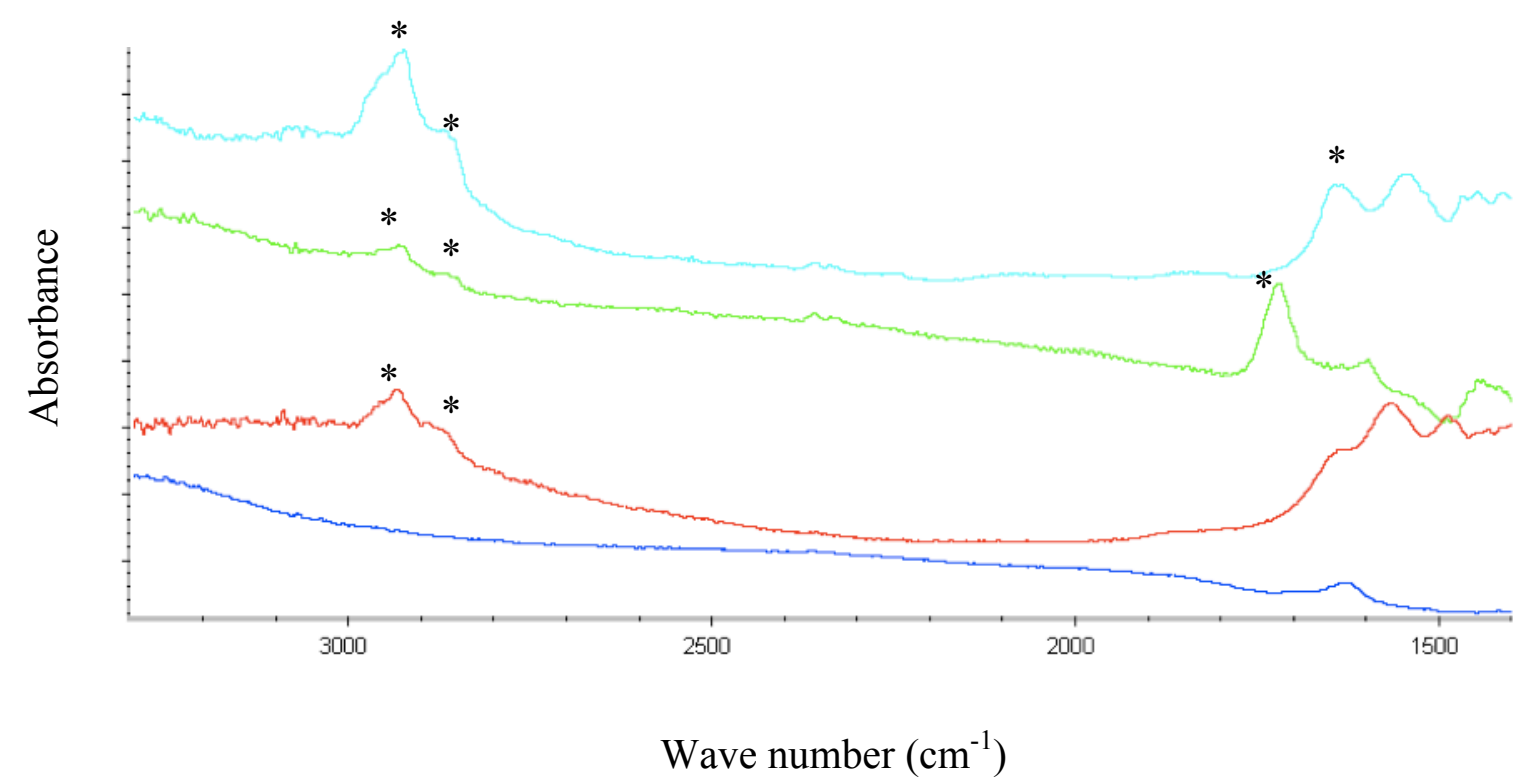

Figure 4. The infrared spectra of MSN materials. The infrared spectrum of $\mathrm{Fe}_{3} \mathrm{O}_{4}-\mathrm{MSN}$ $\mathrm{AP}-\mathrm{Fe}_{3} \mathrm{O}_{4}-\mathrm{MSN}, \mathrm{SA}-\mathrm{Fe}_{3} \mathrm{O}_{4}-\mathrm{MSN}$ and $\mathrm{CA}-\mathrm{Fe}_{3} \mathrm{O}_{4}-\mathrm{MSN}$ are showed in blue, red, green, and light blue, respectively.

The full infrared spectra of materials were shown in Figure 4. $\mathrm{Fe}_{3} \mathrm{O}_{4}-\mathrm{MSN}$ does not have any specific identifiable peak; however, $\mathrm{AP}-\mathrm{Fe}_{3} \mathrm{O}_{4}-\mathrm{MSN}, \mathrm{SA}-\mathrm{Fe}_{3} \mathrm{O}_{4}-\mathrm{MSN}$ and CA$\mathrm{Fe}_{3} \mathrm{O}_{4}$-MSN showed their characteristic peaks for the identification of surface organic functional groups. For example, they have the similar peaks around 2856 and $2936 \mathrm{~cm}^{-1}$ for the alkyl groups. In addition, $\mathrm{SA}-\mathrm{Fe}_{3} \mathrm{O}_{4}-\mathrm{MSN}$ has a peak at $1720 \mathrm{~cm}^{-1}$ for the carboxylic acid and $\mathrm{CA}-\mathrm{Fe}_{3} \mathrm{O}_{4}-\mathrm{MSN}$ has an amide bond peak at $1647 \mathrm{~cm}^{-1}$. 


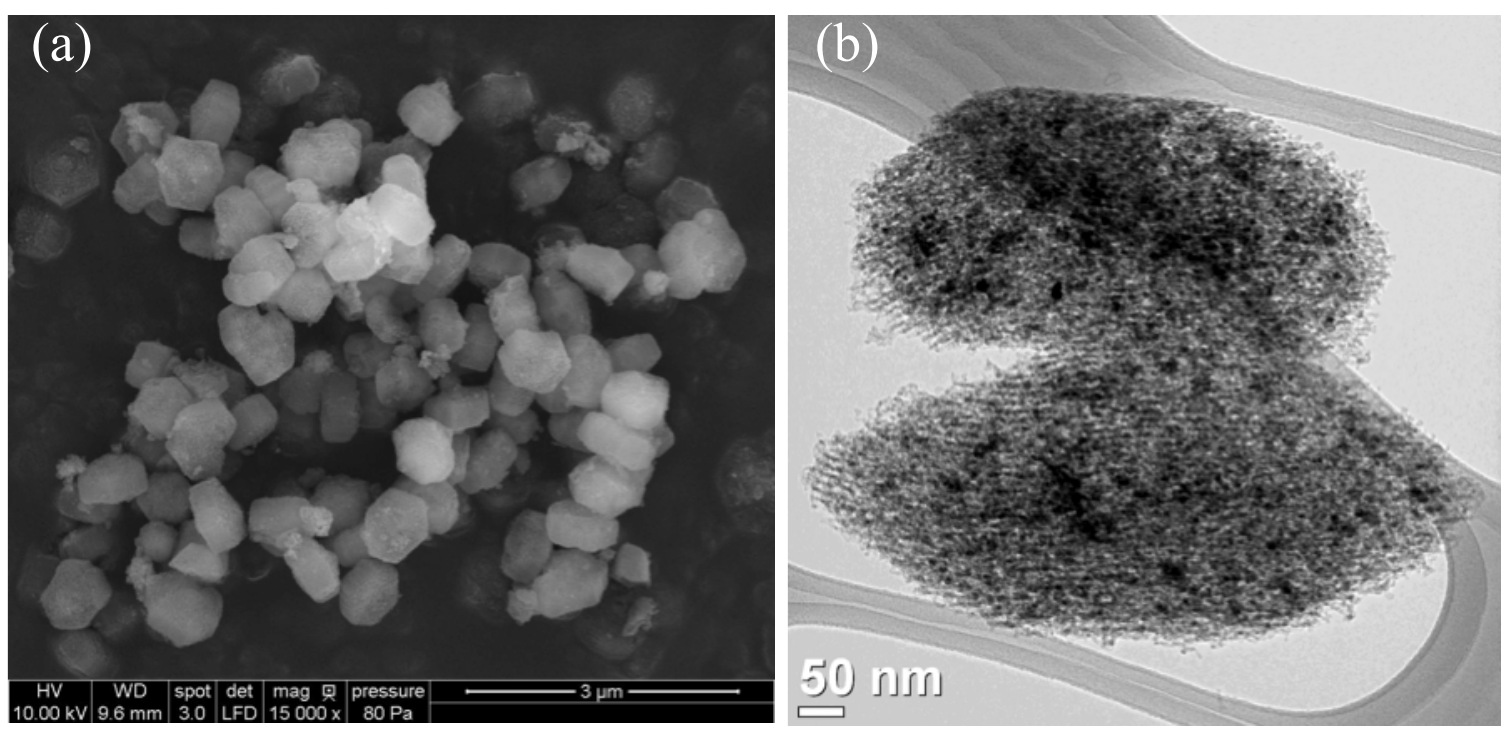

Figure 5. Scanning electron microscopy image (a) and transmission electron microscopy image (b) of $\mathrm{Fe}_{3} \mathrm{O}_{4}$-MSN

The morphology of the MSN materials can be observed in Figure 5. $\mathrm{Fe}_{3} \mathrm{O}_{4}-\mathrm{MSN}$ materials are dish-like hexagons that are roughly $500 \times 250 \mathrm{~nm}$ in size. Clearly, iron oxide nanoparticles can be observed doped inside the mesopore channels. In some small fields, the parallel channels can be observed. Post-synthesis grafting of organic functional groups has demonstrated repeatedly to maintain the MSN morphology and $\operatorname{size}^{14}$; thus, all the materials have the same morphology as $\mathrm{Fe}_{3} \mathrm{O}_{4}-\mathrm{MSN}$.

For protein sequestration studies, both HUVEC and HeLa cells were treated with MSN materials with the desired functionality at $50 \mu \mathrm{g} \mathrm{mL} L^{-1}$ for $4 \mathrm{~h}$. Optical microscopy analysis results indicate that the iron oxide doped MSNs were full of internalized by the cells. The viability of both cell types with the entire series of materials was measured by Quava Via tests (Figure 6). HeLa and HUVEC cells demonstrated biocompatibility with all four tested MSN materials. The cytotoxicity tests indicate that the surface organic functional groups were nontoxic to the cells and demonstrated the same level of 

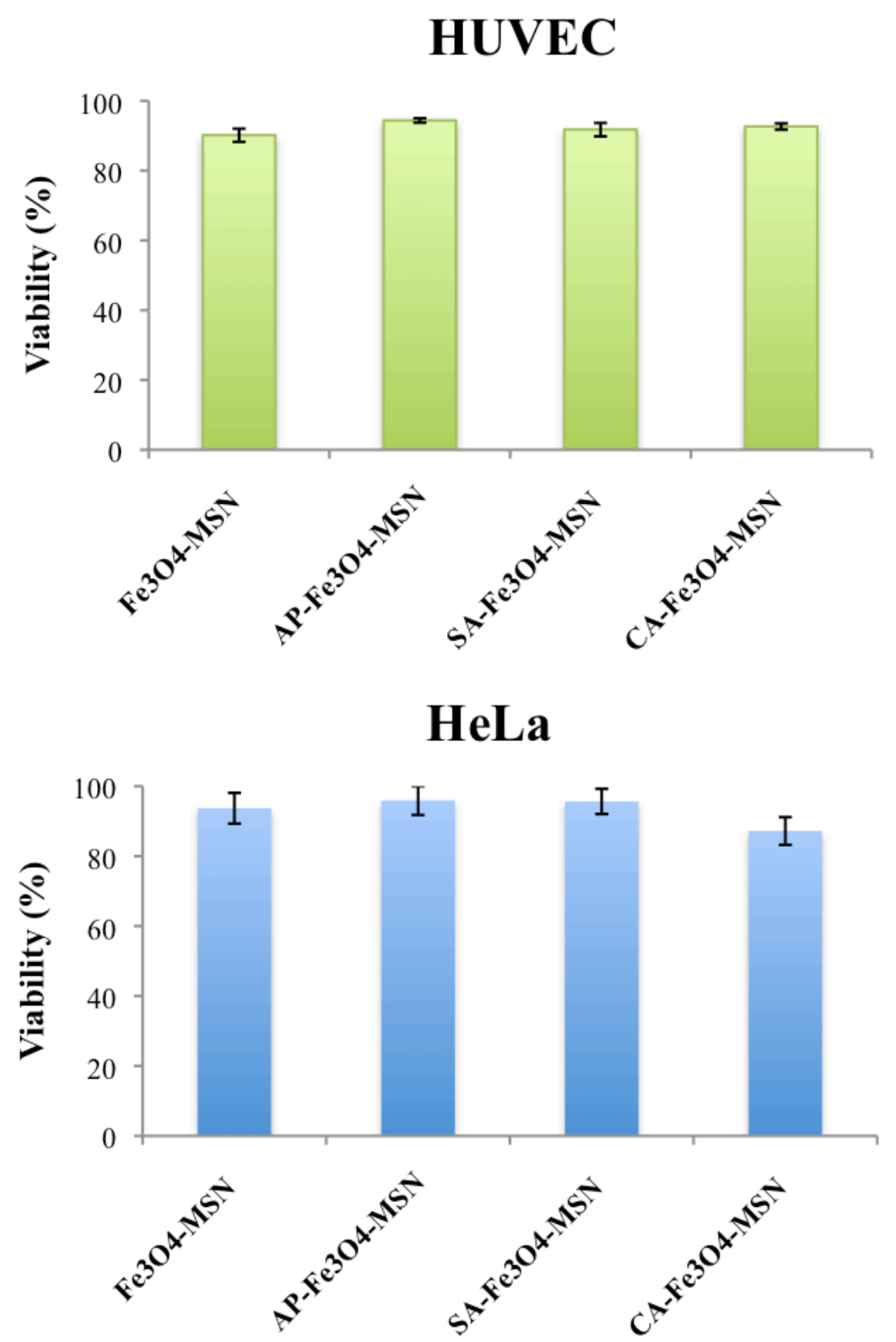

Figure 6. The viability of HUVEC (top) and HeLa (bottom) with the treatment of the desired MSN materials

biocompatibility as the native magnetic MSN. Both cell lines maintained cell viability when incubated with iron oxide MSN suspensions at a concentration of $50 \mu \mathrm{g} \mathrm{mL}^{-1}$.

SDS-PAGE was used for the separation of harvested intracellular proteins; the results are shown on Figure 7. The ladder is a SDS-PAGE standard for proteins with molecular 

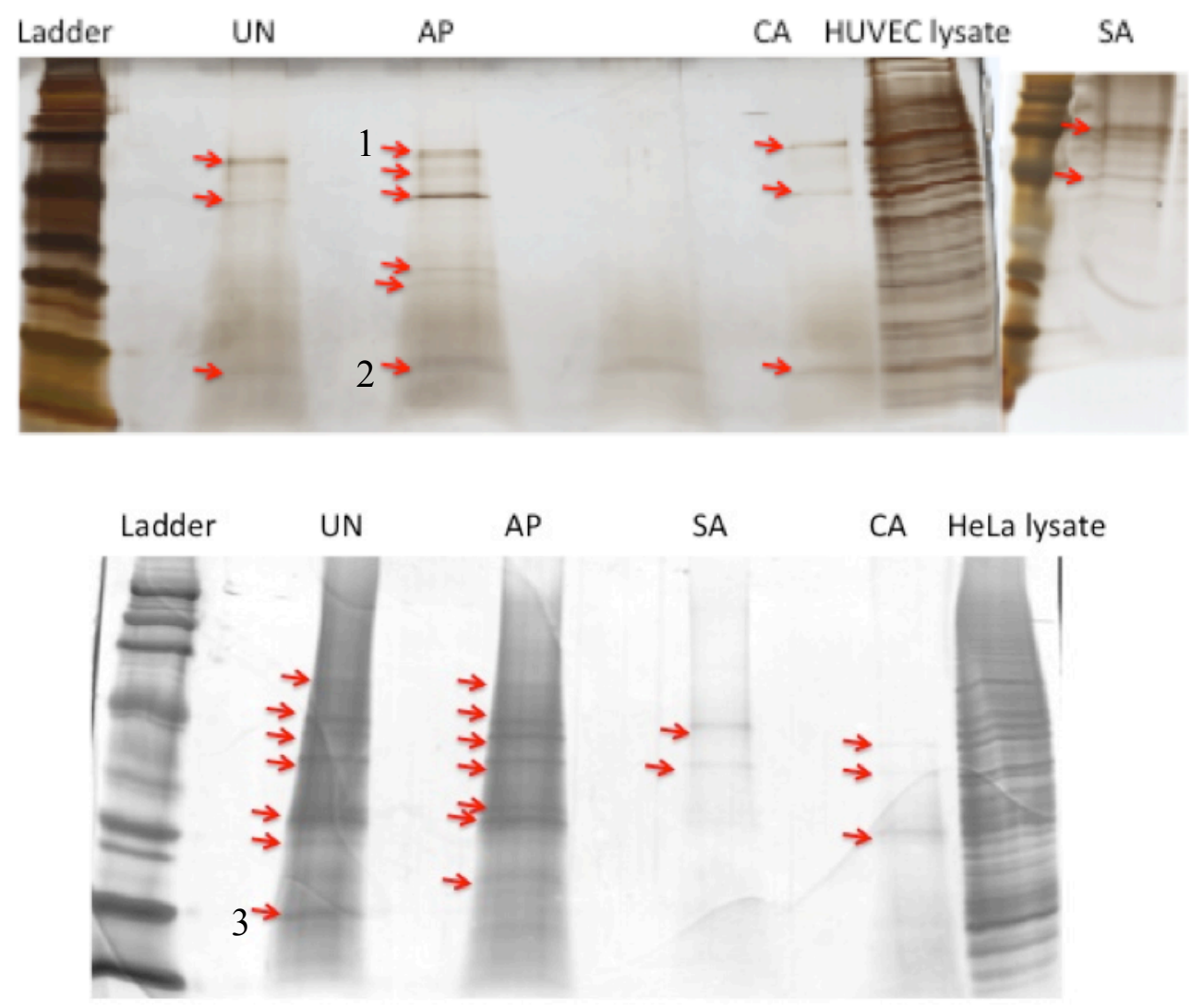

Figure 7. The SDS-PAGE images of extracted proteins from HUVEC cells (top) and HeLa cells (bottom). UN, AP, SA and CA refer to $\mathrm{Fe}_{3} \mathrm{O}_{4}-$ $\mathrm{MSN}, \mathrm{AP}-\mathrm{Fe}_{3} \mathrm{O}_{4}-\mathrm{MSN}, \mathrm{SA}-\mathrm{Fe}_{3} \mathrm{O}_{4}-\mathrm{MSN}$ and $\mathrm{CA}-\mathrm{Fe}_{3} \mathrm{O}_{4}-\mathrm{MSN}$, respectively. The ladder is a protein molecular weight marker. Lysate is from cellular protein solution upon the treatment of cells with $10 \%$ SDS.

weights from 6.9 to $200 \mathrm{kDa}$. $\mathrm{Fe}_{3} \mathrm{O}_{4}$-MSNs with the different surface functional groups have the ability to adsorb and retain proteins. When the surface functionality changed, the amounts and types of proteins captured and sequestered varied among the MSN materials.

For example, $\mathrm{Fe}_{3} \mathrm{O}_{4}$-MSN captured and sequestered three proteins that matched with annexin A2, cytoplasmic actin-1, and $\alpha$-actin-4. ${ }^{2}$ AP- $\mathrm{Fe}_{3} \mathrm{O}_{4}-\mathrm{MSN}, \mathrm{SA}-\mathrm{Fe}_{3} \mathrm{O}_{4}-\mathrm{MSN}$ and 
Table 4. Proteins extracted from MSN materials that were exocytosed by HUVEC or HeLa cells. The proteins were subjected to the MS/MS analysis. The resulting fingerprint spectra were compared to protein databases library using Mascot software. Matches with Mowse scores higher than 27 are expected to be identical or highly homologous $(\mathrm{p}<0.05)$ to the corresponding proteins.

\begin{tabular}{ccccc}
\hline Band & Molecular weight $[\mathrm{kDa}]$ & Protein & $\begin{array}{c}\text { UniProt Accesion } \\
\text { Number }\end{array}$ & $\begin{array}{c}\text { Mowse } \\
\text { Score }\end{array}$ \\
\hline 1 & 112835 & ASAP2 & O43150 & 31 \\
2 & 12947 & RL30 & P62888 & 35 \\
3 & 83398 & CNOTA & Q9H9A5 & 35 \\
\hline
\end{tabular}

$\mathrm{CA}-\mathrm{Fe}_{3} \mathrm{O}_{4}-\mathrm{MSN}$ harvested six, two and three proteins from live HUVECs, respectively. When the concentration of protein is greater, the bands appear darker. Thus, even though the MSN materials have affinity for the proteins with the similar molecular weight, the concentration of harvested proteins are obviously different. Most extracted proteins were related to the concentrated protein bands of cell lysate. Furthermore, $\mathrm{Fe}_{3} \mathrm{O}_{4}-\mathrm{MSN}$, AP$\mathrm{Fe}_{3} \mathrm{O}_{4}-\mathrm{MSN}, \mathrm{SA}-\mathrm{Fe}_{3} \mathrm{O}_{4}-\mathrm{MSN}$ and $\mathrm{CA}-\mathrm{Fe}_{3} \mathrm{O}_{4}-\mathrm{MSN}$ harvested seven, seven, two and three proteins out of HeLa cells within the detection limit of SDS-PAGE, respectively.

In summary, $\mathrm{Fe}_{3} \mathrm{O}_{4}$-MSNs with non-, aminopropyl, carboxylic acid, or hydrophobic cholic acid demonstrated the sequestration of intracellular proteins. Proteins were attracted to the $\mathrm{Fe}_{3} \mathrm{O}_{4}-\mathrm{MSN}$ with specific functional groups at different strengths based on the interaction between proteins and the silica surface. Although $\mathrm{CA}-\mathrm{Fe}_{3} \mathrm{O}_{4}-\mathrm{MSN}$ had smallest measured pore size, it showed selectivity for sequestering intracellular proteins. Selectivity occurred between materials and cell lines. Different materials can carry out different types of proteins on the same cell type. The proteins extracted by the different materials between cell lines showed the distinct patterns. The patterns shown by cells could be regarded as a fingerprint for cell type. With the co-treatment of materials, the 
cell identification can be accomplished.

Some proteins extracted from exocytosed MSN were subjected to MS/MS analysis. Most protein bands cannot be identified correctly because the amount of protein was too dilute or the samples were contaminated by keratin during preparation, which is abundant in hair and fingernails. The three protein bands that were identified are summarized on Table 4. First, ASAP2 protein is localized in the Golgi and in the plasma membrane. ${ }^{15}$ This protein functions to control vesicle budding. In addition, it is involved in the regulation of vesicular transport. Secondly, RL30 is ribosomal protein. ${ }^{16}$ Ribosomes are the organelles that catalyze the synthesis of cellular proteins. The protein is located in the cytoplasm. Finally, CNOTA is a protein (pI 7.95) located in the cytosol. ${ }^{17}$ It is involved in many biological processes such as RNA metabolic process and mRNA metabolic process. Thus, the MSN with a variety of functionality can access the ribosome or Golgi in the cytoplasm. We anticipate that these designed MSN materials can be used to design drug delivery or catalysis systems targeted to specific organelles.

\section{Conclusion}

The synthesis and characterization of a series of iron oxide MSN materials with non-, aminopropyl, carboxylic acid and hydrophobic functional groups was successful. In fact, MSN materials with different functionality can harvest different types of proteins and showed the sensitivity and selectivity between both HUVEC and HeLa cells. They could be used as a fingerprint to distinguish the cell types. Also, they can access some organelles that play the role in the catalysis, metabolism, and trafficking. This will strengthen the potential applications of MSN materials in biological fields. 


\section{References:}

1.(a) Liong, M.; Lu, J.; Kovochich, M.; Xia, T.; Ruehm Stefan, G.; Nel Andre, E.; Tamanoi, F.; Zink Jeffrey, I., Multifunctional inorganic nanoparticles for imaging, targeting, and drug delivery. ACS nano 2008, 2 (5), 889-96; (b) Slowing, I. I.; ViveroEscoto, J. L.; Wu, C.-W.; Lin, V. S. Y., Mesoporous silica nanoparticles as controlled release drug delivery and gene transfection carriers. Advanced Drug Delivery Reviews 2008, 60 (11), 1278-1288; (c) Coti, K. K.; Belowich, M. E.; Liong, M.; Ambrogio, M. W.; Lau, Y. A.; Khatib, H. A.; Zink, J. I.; Khashab, N. M.; Stoddart, J. F., Mechanised nanoparticles for drug delivery. Nanoscale 2009, 1 (1), 16-39; (d) Manzano, M.; Colilla, M.; Vallet-Regi, M., Drug delivery from ordered mesoporous matrices. Expert Opinion on Drug Delivery 2009, 6 (12), 1383-1400; (e) Rosenholm, J. M.; Sahlgren,

C.; Linden, M., Towards multifunctional, targeted drug delivery systems using mesoporous silica nanoparticles - opportunities \& challenges. Nanoscale 2010, 2 (10), 1870-1883; (f) Vivero-Escoto Juan, L.; Slowing Igor, I.; Trewyn Brian, G.; Lin Victor, S. Y., Mesoporous silica nanoparticles for intracellular controlled drug delivery. Small (Weinheim an der Bergstrasse, Germany) 2010, 6 (18), 1952-67; (g) Zhao, Y.; ViveroEscoto, J. L.; Slowing, I. I.; Trewyn, B. G.; Lin, V. S. Y., Capped mesoporous silica nanoparticles as stimuli-responsive controlled release systems for intracellular drug/gene delivery. Expert Opinion on Drug Delivery 2010, 7 (9), 1013-1029; (h) Ambrogio, M. W.; Thomas, C. R.; Zhao, Y.-L.; Zink, J. I.; Stoddart, J. F., Mechanized Silica Nanoparticles: A New Frontier in Theranostic Nanomedicine. Accounts of Chemical Research 2011, 44 (10), 903-913; (i) Chidambaram, M.; Manavalan, R.; Kathiresan, K., Nanotherapeutics to overcome conventional cancer chemotherapy limitations. Journal of pharmacy \& pharmaceutical sciences : a publication of the 
Canadian Society for Pharmaceutical Sciences, Societe canadienne des sciences pharmaceutiques 2011, 14 (1), 67-77; (j) Lee, J. E.; Lee, N.; Kim, T.; Kim, J.; Hyeon, T., Multifunctional Mesoporous Silica Nanocomposite Nanoparticles for Theranostic Applications. Accounts of Chemical Research 2011, 44 (10), 893-902; (k) Popat, A.; Hartono, S. B.; Stahr, F.; Liu, J.; Qiao, S. Z.; Lu, G. Q., Mesoporous silica nanoparticles for bioadsorption, enzyme immobilisation, and delivery carriers. Nanoscale 2011, 3 (7), 2801-2818; (1) Rosenholm, J. M.; Sahlgren, C.; Linden, M., Multifunctional mesoporous silica nanoparticles for combined therapeutic, diagnostic and targeted action in cancer $\mathrm{t}$ treatment. Current Drug Targets 2011, 12 (8), 1166-1186; (m) Simovic, S.; GhouchiEskandar, N.; Sinn Aw, M.; Losic, D.; Prestidge Clive, A., Silica materials in drug delivery applications. Current drug discovery technologies 2011, 8 (3), 269-76.

2.Slowing, I. I.; Vivero-Escoto, J. L.; Zhao, Y.; Kandel, K.; Peeraphatdit, C.; Trewyn, B. G.; Lin, V. S. Y., Exocytosis of Mesoporous Silica Nanoparticles from Mammalian Cells: From Asymmetric Cell-to-Cell Transfer to Protein Harvesting. Small (Weinheim an der Bergstrasse, Germany) 2011, 7 (11), 1526-1532.

3.(a) Deere, J.; Magner, E.; Wall, J. G.; Hodnett, B. K., Adsorption and activity of proteins onto mesoporous silica. Catal. Lett. 2003, 85 (1-2), 19-23; (b) Yang, J.; Stevens, G. W.; O'Connor, A. J., Adsorption of lysozyme and trypsin by modified MCM-41 with post-synthesis hydrothermal treatment and hydrophobic functionalisation. J. Aust. Ceram. Soc. 2008, 44 (1), 1-6; (c) Yang, J.; Daehler, A.; Stevens, G. W.; O'Connor, A. J., Adsorption of lysozyme and trypsin onto mesoporous silica materials. Studies in Surface Science and Catalysis 2003, 146 (Nanotechnology in Mesostructured Materials), 775-778; (d) Kisler, J. M.; Stevens, G. W.; O'Connor, A. J., Adsorption of 
proteins on mesoporous molecular sieves. Mater. Phys. Mech. 2001, 4 (2), 89-93; (e) Matsuura, S.-i.; Itoh, T.; Ishii, R.; Tsunoda, T.; Sakaguchi, K.; Hanaoka, T.; Mizukami, F., Encapsulation of fluorescent proteins in folded-sheet mesoporous materials: Effect of pore size on energy-transfer efficiency. Microporous Mesoporous Mater. 2010, 131 (13), 245-251; (f) Lei, C.; Shin, Y.; Liu, J.; Ackerman, E. J., Entrapping Enzyme in a Functionalized Nanoporous Support. J. Am. Chem. Soc. 2002, 124 (38), 11242-11243; (g) Diaz, J. F.; Balkus, K. J., Jr., Enzyme immobilization in MCM-41 molecular sieve. J. Mol. Catal. B Enzym. 1996, 2 (2-3), 115-126; (h) Chaudhary, Y. S.; Manna, S. K.; Mazumdar, S.; Khushalani, D., Protein encapsulation into mesoporous silica hosts. Microporous Mesoporous Mater. 2008, 109 (1-3), 535-541; (i) Ho, J.; Danquah, M. K.; Wang, H.; Forde, G. M., Protein loaded mesoporous silica spheres as a controlled delivery platform. J. Chem. Technol. Biotechnol. 2008, 83 (3), 351-358; (j) Hudson, S.; Cooney, J.; Magner, E., Proteins in mesoporous silicates. Angewandte Chemie, International Edition 2008, 47 (45), 8582-8594; (k) Casadonte, F.; Pasqua, L.; Savino, R.; Terracciano, R., Smart Trypsin Adsorption into N-(2-Aminoethyl)-3-aminopropylModified Mesoporous Silica for Ultra Fast Protein Digestion. Chemistry--A European Journal 2010, 16 (30), 8998-9001, S8998/1-S8998/19.

4.Jiang, X.-U.; Roecker, C.; Hafner, M.; Brandholt, S.; Doerlich, R. M.; Nienhaus, G. U., Endo- and Exocytosis of Zwitterionic Quantum Dot Nanoparticles by Live HeLa Cells. ACS nano 2010, 4 (11), 6787-6797.

5.(a) Chen, R.; Huang, G.; Ke, P. C., Calcium-enhanced exocytosis of gold nanoparticles. Appl. Phys. Lett. 2010, 97 (9), 093706/1-093706/3; (b) Chithrani, B. D.; Chan, W. C. 
W., Elucidating the Mechanism of Cellular Uptake and Removal of Protein-Coated Gold Nanoparticles of Different Sizes and Shapes. Nano Lett. 2007, 7 (6), 1542-1550.

6.Jin, H.; Heller, D. A.; Sharma, R.; Strano, M. S., Size-Dependent Cellular Uptake and Expulsion of Single-Walled Carbon Nanotubes: Single Particle Tracking and a Generic Uptake Model for Nanoparticles. ACS nano 2009, 3 (1), 149-158.

7.Panyam, J.; Labhasetwar, V., Dynamics of Endocytosis and Exocytosis of Poly(D,LLactide-co-Glycolide) Nanoparticles in Vascular Smooth Muscle Cells. Pharm. Res. 2003, 20 (2), 212-220.

8.Dombu, C. Y.; Kroubi, M.; Zibouche, R.; Matran, R.; Betbeder, D., Characterization of endocytosis and exocytosis of cationic nanoparticles in airway epithelium cells. Nanotechnology 2010, 21 (35), 355102/1-355102/8, S355102/1.

9.Hu, L.; Mao, Z.; Zhang, Y.; Gao, C., Influences of size of silica particles on the cellular endocytosis, exocytosis and cell activity of HepG2 cells. J. Nanosci. Lett. 2011, 1 (1), $1-16$.

10.(a) Liu, S.; Chen, H.; Lu, X.; Deng, C.; Zhang, X.; Yang, P., Facile synthesis of copper(II) immobilized on magnetic mesoporous silica microspheres for selective enrichment of peptides for mass spectrometry analysis. Angewandte Chemie, International Edition 2010, 49 (41), 7557-7561, S7557/1-S7557/15; (b) Shao, M.; Ning, F.; Zhao, J.; Wei, M.; Evans, D. G.; Duan, X., Preparation of Fe3O4@SiO2@Layered Double Hydroxide Core-Shell Microspheres for Magnetic Separation of Proteins. J. Am. Chem. Soc. 2012, 134 (2), 1071-1077; (c) Liu, Q.; Shi, J.; Cheng, M.; Li, G.; Cao, D.; Jiang, G., Preparation of graphene-encapsulated magnetic microspheres for 
protein/peptide enrichment and MALDI-TOF MS analysis. Chem. Commun. (Cambridge, U. K.) 2012, 48 (13), 1874-1876.

11.Han, S.-I.; Lim, J. S.; Kim, D. K.; Kim, M. N.; Im, S. S., In situ polymerized poly(butylene succinate)/silica nanocomposites: Physical properties and biodegradation. Polymer Degradation and Stability 2008, 93 (5), 889-895.

12.Li, J.; Suo, J.; Deng, R., Structure, mechanical, and swelling behaviors of poly(vinyl alcohol)/SiO2 hybrid membranes. Journal of Reinforced Plastics and Composites 2010, $29(4), 618-629$.

13.Zhang, W.; Chen, S.; Hu, W.; Zhou, B.; Yang, Z.; Yin, N.; Wang, H., Facile fabrication of flexible magnetic nanohybrid membrane with amphiphobic surface based on bacterial cellulose. Carbohydrate Polymers 2011, 86 (4), 1760-1767.

14.Fang, I. J.; Slowing, I. I.; Wu, K. C. W.; Lin, V. S. Y.; Trewyn, B. G., Ligand Conformation Dictates Membrane and Endosomal Trafficking of Arginine-GlycineAspartate (RGD)-Functionalized Mesoporous Silica Nanoparticles. Chemistry--A European Journal 2012, 18 (25), 7787-7792.

15.Sabe, H.; Onodera, Y.; Mazaki, Y.; Hashimoto, S., ArfGAP family proteins in cell adhesion, migration and tumor invasion. Current Opinion in Cell Biology 2006, 18 (5), $558-564$.

16.Yoshihama, M.; Uechi, T.; Asakawa, S.; Kawasaki, K.; Kato, S.; Higa, S.; Maeda, N.; Minoshima, S.; Tanaka, T.; Shimizu, N.; Kenmochi, N., The human ribosomal protein genes: sequencing and comparative analysis of 73 genes. Genome Research 2002, 12 (3), 379-390. 


\section{CONT10.}

http://www.phosphosite.org/proteinAction. $d o ?$ id $=3618825 \&$ showAllSites $=$ true.. 


\title{
CHAPTER 4. THE PROGRAMMABLE ENDOCYTOSIS BEHAVIOR OF MESOPOROUS SILICA NANOPARTICLES
}

\author{
I-Ju Fang, Brian G. Trewyn* and Victor S.-Y. Lin
}

\begin{abstract}
The protein, bovine serum albumin (BSA), is noncovalently linked to the external surface of biotin functionalized mesoporous silica nanoparticle (MSN) materials through the avidin-biotin bridge with a cleavable disulfide ligand. This system was designed to determine how the biomolecule functionalization on MSN surface influences the endocytosis efficiency of mesoporous silica nanoparticles toward cancer cells. We focused on developing a method for dual layer protein deposition on MSN surface to control the endocytosis behavior toward cells. These materials were treated with DTT and the enzyme, trypsin, in order to examine the effects of thiol reducing antioxidants and proteases on the endocytosis behavior of cells.

Avidin immobilized MSN materials have greater affinity for biotinylated (BSA-B) than native MSN (unfunctionalized). Once BSA is functionalized on the MSN surface, it shows the opposite charge behavior for avidin-immobilized MSN. Because both proteins have opposite charges and different size, they change surface property of MSN immediately, furthermore change the endocytosis efficiency of MSN toward cancer cells quickly. As a result, we can manipulate the endocytotic behavior of MSN by simply linking biotinylated biomolecules on MSN. Once the protein immobilized MSN materials encounter a reducing reagent or protease the release of proteins from the MSN surface is
\end{abstract}


triggered, the endocytotic efficiency will be changed. Finally, the cellular endocytosis efficiency of MSN materials can be easily manipulated by changing identity of the surface bound protein, the reducing reagent and protease.

\section{Introduction}

The construction of functional and organized biomolecule-containing multilayer films is one of the focal subjects in biomaterials and biotechnology. There are mainly two principles for the construction of biomolecule-containing multilayers. ${ }^{4}$ One method is based on the electrostatic attraction between opposite charges. ${ }^{5,6}$ The formation of multilayer assemblies using this method was first realized by consecutively alternating adsorption of anionic and cationic polyelectrolytes. This technique has been utilized to construct multilayer protein-containing films by the adsorption of oppositely charged polyelectrolytes and proteins. However, great effort is needed to control the nonspecific adsorption between proteins and polyelectrolytes. Furthermore, this electrostatic adsorption method is not very suitable for all protein molecules because solution $\mathrm{pH}$ value and ionic strength can affect the bio-multilayers obtained by this method.

The other way to construct protein multilayers with ordered structure is to employ the biological specific interactions such as antibody-antigen and biotin-avidin. ${ }^{7,8}$ For example, the multilayer can be constructed by means of avidin-biotin interaction. The remarkable strength of the interaction between the egg-white avidin and the vitamin biotin has attracted a great deal of attention for more than 50 years. This unique property is the main reason that the avidin-biotin system has been frequently used in many biotechnological applications. Owing to the high affinity and stable nature of the 
resulting complex, the avidin-biotin system is currently widely used to label biomolecules with dyes, fluorophores, enzymes, etc. ${ }^{9}$ This type of interaction is one of the strongest known non-covalent that includes binding between proteins and ligands. The binding constant between avidin and biotin analogs is $5.0 \times 10^{15} \mathrm{M}^{-1}$.,3 The bond formation between biotin and avidin is very rapid and once formed, is unaffected by wide extremes of $\mathrm{pH}(2-13)$, temperature (up to $120^{\circ} \mathrm{C}$ ), organic solvents and other denaturing agents. ${ }^{10}$ Moreover, avidin can also bind compounds shown on Table 1 to form metastable complexes. ${ }^{11}$ Thus, the biomolecule containing multilayer can be constructed by taking advantage of the stable avidin-biotin complex or other metastable avidin-biotin analogue complex.

The multilayer assemblies stated above could be applied to MSN surface as a cap in drug delivery systems or target marker for endocytosis study of MSN materials. The avidin-biotin interaction was chosen as a linker to construct dual layers on the MSN surface. This work presents a unique method for the design of multicapping proteins on the surface of MSN materials through small biotin ligands. Avidin is regarded to as a universal receptor for biotinylated compounds or proteins. ${ }^{12}$ For instance, avidin can be conjugated with BSA-B and biotinylated $\mathrm{IgG}$, and antibody. ${ }^{12-14}$ Avidin and BSA-B were used to demonstrate the feasibility of attaching dual layers of proteins on the MSN surface. Initially, biotin functionalized MSNs are synthesized via amidation of biotin NHS ester with aminoprypyl groups on MSN. On the surface of biotin functionalized MSNs, protein multilayers made up of avidin and BSA-B are constructed via avidinbiotin bond. Avidin will form a stable complex with the BSA-B on biotin functionalized MSNs by taking advantage of an electrostatic force of attraction, hydrogen bonding, and 
avidin-biotin interaction. The bioaffinity exists only between avidin and BSA-B, but not native BSA. ${ }^{14}$

Avidin (MW 68,000 Da) is ellipsoidal protein, with dimensions of $5.6 \mathrm{~nm}$ x $5.0 \mathrm{~nm}$ x $4.0 \mathrm{~nm} .{ }^{15}$ Avidin has be used as building blocks for the construction of multilayer deposition because the dihedral D2 molecular symmetry of the avidin homotetramer positions two pairs of biotin binding sites on opposite faces of the protein, which opens possibilities to construct multilayer architectures. ${ }^{16}$ Simply speaking, these four binding sites are located in pairs on either side of protein molecule. Thus, upon binding to a biotin-analogue ligand (Figure 1) via both binding sites on one face of the protein, the binding sites on the opposite face are accessible to other biotin analogue. Totally, avidin contains four identical binding sites to biotin. Binding between avidin and biotin is an

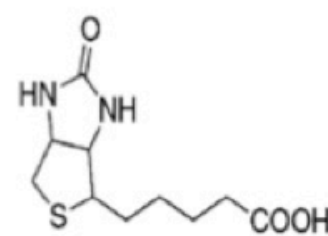

biotin

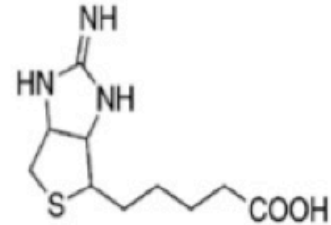

2-iminobiotin

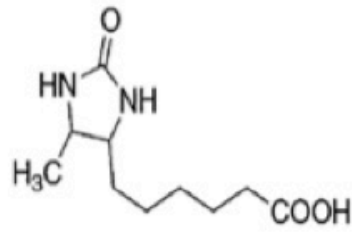

desthiobiotin

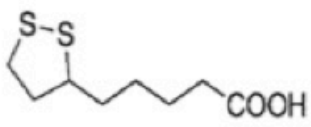

lipoic acid

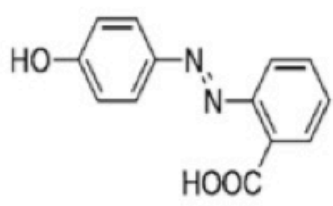

2-(4'-hydroxyphenylazo)benzoic acid

Figure 1. Biotin analogue ${ }^{1}$ 
irreversible process. Avidin is extremely stable to thermal denaturation. The molar extinction coefficient of avidin is $97400 \mathrm{M}^{-1} \mathrm{~cm}^{-1}$ at $280 \mathrm{~nm}$. Because the isoelectric point of avidin is $\mathrm{pH} 10.5$, it is the basic protein contains net positive charge at a physiological $\mathrm{pH}$. Although avidin was used on MSN surface as a cap in a drug delivery system ${ }^{17,18}$, no study related to the endocytosis of avidin-MSNs has been reported. Moreover, the most important thing is that avidin can bind to sugar-binding lectin, which highly expressed on tumor cell surface. Lectin helped the accumulation of avidin in cancer cells because of the binding between lectin and avidin. ${ }^{19,20}$ Avidin could improve the cellular accumulation of MSN materials in HeLa cells potentially.

Table 1. The binding ability of ligand to avidin., ${ }^{2,3}$

\begin{tabular}{|c|c|}
\hline ligand & The binding constant of ligand to avidin $\left(\mathrm{M}^{-1}\right)$ \\
\hline biotin & $1 \times 10^{15}$ \\
\hline dethiobiotin & $\begin{array}{c}5 \times 10^{13} \\
10^{3} \text { in the acidic solution }\end{array}$ \\
\hline 2-iminobiotin & $1.4 \times 10^{6}$ \\
\hline lipoic acid & $1.7 \times 10^{5}$ \\
\hline $\begin{array}{c}\text { 2-(4- } \\
\text { Hydroxyphenylazo)benzoic } \\
\text { acid (HABA) }\end{array}$ & \\
\hline
\end{tabular}


Biotin (MW 244 Da, vitamin H) forms a very stable complex with avidin. Avidin also binds analogue compounds of biotin such as lipoic acid, desthiobiotin, 2-iminobiotin and 2-[(4-hydroxybenzene)azo]benzoic acid (HABA) (Figure 1). There are many differences in the bioaffinity between biotin and biotin-analogue compounds to the binding protein, avidin. The binding site and source of strong interaction of avidin for biotin is a collection of hydrogen bonding between biotin and amino acid residues. ${ }^{21,22}$ Biotin is completely buried in the binding sites of avidin. The fused biotin-ring system forms a network of hydrogen-bonding interactions. The ureido moiety of biotin in the bound state forms hydrogen bonds to five residues, three for the carbonyl oxygen and one for each NH group. These five hydrogen bonds act cooperatively; as a result, it leads to stabilization that is larger than the sum of individual hydrogen-bonding energies. In the avidin-biotin complex, one of the carboxylate $\mathrm{O}$ atoms forms three hydrogen bonds with Thr38 O, Ala39 N and Thr40 N and the other forms two hydrogen bonds with Ser73 O and Ser75 O. ${ }^{21}$

Bovine serum albumin (MW $66430 \mathrm{Da}$ ) is also ellipsoidal protein with dimensions of $14.0 \mathrm{~nm} \times 4.0 \mathrm{~nm} \times 4.0 \mathrm{~nm}$. The commercial availability of albumins at high purity (generally $\geq 96 \%$ ) and at low cost together with their high water solubility, is favorable for their use as preferred modification platform. Albumins with relatively high lysine residues are desired because the primary amine on lysine amino acids are often used to derivatize proteins with biotin, BSA has 59 lysine residues. The pI of BSA is 4.7 , so BSA has the electrostatic force of attraction for avidin at $\mathrm{pH}$ 7.4. Extinction coefficient of BSA is $0.667 \mathrm{ml} \mathrm{mg}^{-1} \mathrm{~cm}^{-1}$ at $280 \mathrm{~nm}$. It was reported that there were on average $3.5-9$ biotin analogue ligands bound to each BSA molecule through the derivative of lysine residues 
of BSA. ${ }^{11,12,14}$ Avidin, being a tetramer, cross-links BSA via its covalently bound ligands, biotin (at least two biotins per BSA). Thus, it is possible that BSA-B can bind up to 4 avidins, and the multilayers made up of BSA-B and avidin will be constructed. Herein, BSA can be regarded as a model biotinylated-macromolecule. BSA does not have any interaction with bioitn. ${ }^{23}$ The synthesis and design of this work could be applied to biotinylated biomolecule or avidin-bound protein. ${ }^{24-26}$ Basically, any macromolecule can be linked to MSN through this interaction. Once a biomolecule is immobilized on the MSN surface by an avidin-biotin bridge, the endocytosis behavior of MSN will be changed with the nature of macromolecule. Furthermore dual-layer protein immobilized MSN materials possess the cleavable disulfide bond between surface biotin and silica surface. Thus, the endocytosis of protein immobilized MSNs could be governed by the disulfide reducing reagent and the protease. The dithiothreitol (DTT) and trypsin were chosen to mimic the biological environment that protein immobilized MSN will encounter. If this type of protein (macromolecule) capped mesoporous silica nanoparticle material can be applied as a drug delivery vehicle, the endocytosis efficiency and the percent of intracellular distribution of the release system could potentially be finelycontrolled.

\section{Experimental Section}

Chemicals. Avidin, BSA, fluorescein isothiocyanate isomer I, tetraethyl orthosilicate (TEOS), trypsin, dithiothreitol and $N$-cetyltrimethylammonium bromide were purchased from Sigma-Aldrich. Organic silanes, 3-aminopropyltrimethoxysilane (APTMS) was purchased from Gelest. NHS-Biotin and Sulfo-NHS-SS-Biotin were 
obtained from Thermoscientific.

\section{Synthesis of MSNs}

The MSN materials were synthesized by the co-condensation method. ${ }^{27}$ First, $N$ cetyltrimethylammonium bromide (CTAB, $1.00 \mathrm{~g}, 2.74 \mathrm{mmol})$ was dissolved in $480 \mathrm{~mL}$ of nanopure water. A solution of sodium hydroxide $(2.00 \mathrm{M}, 3.50 \mathrm{~mL})$ was introduced to the CTAB solution at 80 degree. Tetraethoxysilane (TEOS, $5.00 \mathrm{~mL}, 22.4 \mathrm{mmol}$ ) was added dropwise by syringe pump to the surfactant solution at a rate $30 \mathrm{ml} /$ hour under vigorous stirring. Also, the FITC isomer reacted with APTMS for $2 \mathrm{~h}$ in methanol in advance, and then this solution was added in to MSN suspension to mix well. The solution was allowed to react for $2 \mathrm{~h}$ to produce a white precipitate, followed by filtration and washing with copious amount of water and methanol to yield an as-made MSN. The resulting as-made MSN were dried under high vacuum overnight.

\section{Synthesis of amino group functionalized-MSN (Amine-MSN):}

The MSN material is further functionalized with 3-aminopropyltriethoxysilane coupling reagent through a post synthetic grafting method. Typically the as-made MSN

(1 g) was refluxed with 3-aminopropyltriethoxysilane $(1 \mathrm{mmol})$ in the $80 \mathrm{ml}$ of anhydrous toluene at $110^{\circ} \mathrm{C}$, followed by washing with deionized water and methanol. Then, dried under high vacuum to yield as synthesized amino functionalized MSN (Amine-MSN).

Biotin-conjugated of amino group functionalized-MSN with cleavable disulfide bond (B-SS-Amine-MSN) 
Amine-MSN (0.55 g) was dispersed in $20 \mathrm{ml}$ PBS buffer and then followed by an introduction of biotin-NHS ester solution (Sulfo-NHS-SS-Biotin $(125 \mathrm{mg})$ dissolved in 2 $\mathrm{ml}$ DMSO) and stirred at room temperature overnight. To remove the surfactant template (CTAB) from synthesized B-SS-AmineE-MSN, the B-SS-AmineE-MSN (1.0 g) was refluxed in an acidic methanolic solution $(1.00 \mathrm{~mL}$ of concentrated $\mathrm{HCl}$ in $100.00 \mathrm{~mL}$ methanol) at $60{ }^{\circ} \mathrm{C}$ for $6 \mathrm{~h}$. The extracted material was filtered, extensively washed with deionized water and methanol, and dried under high vacuum to yield the biotin grafted MSN.

\section{The immobilization of protein on B-SS-Amine-MSN surface}

\section{Biotinylated Protein (ex. BSA-B)}

Biotin N-hydroxysuccinimide ester dissolved in dimethyl sulfoxide (DMSO, $0.50 \mathrm{ml}$ ) was added to a solution of proteins dissolved in phosphate buffered saline ( $\mathrm{pH} \mathrm{7.4),} \mathrm{and}$ stirred overnight. The solution was dialyzed in PBS, containing 5\% DMSO, for 1 day. Following dialysis with Milli-Q water, a white product was obtained by freeze-drying. The biotins ligands bound to BSA were quantified via the HABA assay. In this work, one BSA has 5.3 biotin ligands averagely by HABA assay.

\section{Protein immobilized MSN}

Avidin-PBS solution (1.0 mg in $1 \mathrm{ml}, \mathrm{pH} 7.4)$ and biotinylated protein-PBS solution ( $3 \mathrm{mg}$ in $3 \mathrm{ml}, \mathrm{pH}$ 7.4) were separately prepared. First, B-SS-Amine-MSN was dispersed into the avidin solution, stirred overnight at room temperature. Following stirring, the biotinylated protein-PBS solution was added to the MSN suspension. The solution was centrifuged and washed by PBS three times to get rid of excess proteins to yield the protein immobilized MSN via biotin-avidin linkage. Avidin immobilized on B-SS- 
Amine-MSN is called Avi-B-SS-Amine-MSN. BSA-B bound to Avi-B-SS-Amine-MSN through biotin linker is called BSA-B-Avi-B-SS-Amine-MSN.

\section{Assay for ligand content}

To quantify the ligand loading, a displacement test for avidin-HABA complex with biotin-related compounds was conducted. The ligand to BSA ratio in the BSA-B conjugate is determined by a HABA (2-(4-Hydroxyphenylazo)benzoic acid) displacement assay. The ligand content will be determined by gradually adding a small portion of BSA-B conjugate to phosphate solution containing avidin and HABA with the certain concentration. (The concentration of HABA is much greater that that of avidin). It is known that HABA exhibits a strong absorption at $500 \mathrm{~nm}$ when complexed with avidin while absorbance of free HABA is negligibly small at this wavelength. ${ }^{20,28-31}$ Addition of HABA in excess to avidin under conditions where almost all of it is bound gives a new absorption band at $500 \mathrm{~nm}$ and a color change from yellow to red $\left(\varepsilon_{500}\right.$ increases from 600 to $34500 \mathrm{M}^{-1} \mathrm{~cm}^{-1}$ ). At the same time the intensity of the $348 \mathrm{~nm}$ band of HABA decreases. These changes are reversed by the addition of biotin to avidin. A small amount of biotin or biotin analogue was added into the HABA-avidin solution. The absorbance at $500 \mathrm{~nm}$ decreases rapidly upon addition of biotin or biotin analogues, suggesting that the bound HABA is displaced by biotin or biotin analogues since the binding constant between biotin or biotin analogues and avidin is much higher than that for HABA-avidin complexation (ca. $1.7 \times 10^{5} \mathrm{M}^{-1}$ in solution). The change in absorbance at $500 \mathrm{~nm}$ was measured after successive additions of standard biotin analogue solutions with a micropipet until no further change occurred. Biotin or biotin analogues displaces HABA to an extent dependent on their binding constants. 
The HABA content is calculated from the HABA specific absorbance at $348 \mathrm{~nm}$. The protein concentration is calculated from the absorbance at $280 \mathrm{~nm}$, using a series of BSA standards. As a result, the ligand content of the protein is calculated.

\section{Material Characterization:}

Powder X-ray diffraction (PXRD) was performed on a 2-Theta type X-ray diffractometer using $\mathrm{Cu}-\mathrm{K} \alpha$ radiation. The nitrogen gas sorption analysis was measured on a Tristar analyzer. A thermogravimetric analyzer 2950 manufactured by TA Instruments was used for thermogravimetric analysis (TGA) measurement of silica samples. The samples were heated from room temperature to $800{ }^{\circ} \mathrm{C}$ at ramping rate of $2{ }^{\circ} \mathrm{C} / \mathrm{min}$ in air. Scanning electron microscopy (SEM) images were recorded on a Quanta 250 FEG Scanning Electron Microscope made by the FEI Company. The $\zeta$-potential of the MSN materials was measured in a Malvern Nano HT Zetasizer in triplicate. Suspensions $\left(100 \mu \mathrm{g} \mathrm{mL}^{-1}\right)$ of each of the materials in phosphate buffer $(10 \mathrm{mM}, \mathrm{pH} 7.4)$ were prepared.

\section{Biological Experiment}

\section{Reagents and materials}

HeLa cell line was obtained from American Tissue Culture Collection (ATCC). Trypsin $(1 \times, 0.25 \%)$ in $0.1 \%$ EDTA without calcium and magnesium was purchased from Fisher Scientific. 


\section{Cell line maintenance}

HeLa cells were maintained in D-10 media in T75 flasks using DMEM (Dulbucco's modified Eagle's medium) supplemented with $10 \%$ equine serum, l-glutamine, penicillin, streptomycin, and gentamicin. HeLa cells were split every 2-3 days.

\section{Fluorescence confocal microscopy measurements}

To study the endocytosis of MSN materials, fluorescence confocal microscopy was employed. Coverslips $\left(22 \mathrm{~mm}^{2}\right)$ were cleaned with surfactant (Contrad 70$)$, nanopure water $(3 \times)$, and $100 \%$ methanol, and dried overnight and followed by polylysine coating. The polylysine coated coverslips were placed on the bottom of the wells of 6-well plates and incubated with $3.0 \mathrm{~mL}$ of standard D-10 growth media. Two samples were prepared for the confocal microscopy study. First, HeLa $\left(1.0 \times 10^{5}\right.$ cells $\left.\mathrm{mL}^{-1}\right)$ were grown for $30 \mathrm{~h}$ on the coverslips. After $30 \mathrm{~h}$ cell growth, the cells were incubated with $2 \mu \mathrm{g} \mathrm{mL}{ }^{-1} \mathrm{MSN}$ materials with endosome marker FM 4-64, and grown for an additional 13-17 h. Afterwards, the growth media was removed, the cells were washed with PBS $(2 \times)$, and the cells were then reincubated with Hoechst 33258 for 15 min to stain the cell nucleus. These coverslips were removed and fixed to glass slides with adhesive. Blue nuclei stain was observed by exciting the cells with a UV laser at $340 \mathrm{~nm}$. The green fluorescent from MSN (FITC prelabeled) particles internalized by the HeLa cells was visualized by excitation at $488 \mathrm{~nm}$ with an argon laser. The red fluorescent endosome marker was excited at $515 \mathrm{~nm}$. 
DTT treatment Materials $(10 \mathrm{mg})$ were treated with DTT at $50 \mathrm{mM}$ overnight. Materials were washing by water to remove chemicals adsorbed on surface, and then dried under vacuum.

The digestion of protein immobilized by trypsin Materials $(10 \mathrm{mg})$ were treated with trypsin at $1 \mathrm{mg} \mathrm{ml}^{-1}$ overnight at $37^{\circ} \mathrm{C}$. Materials were washing by water to remove peptides adsorbed on surface, and then dried under vacuum.

\section{Results and Discussion}

(a)

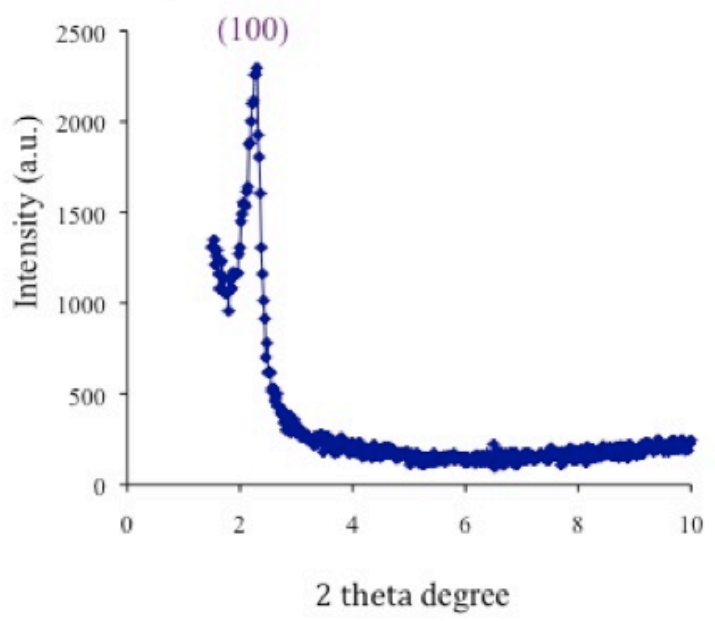

(b)

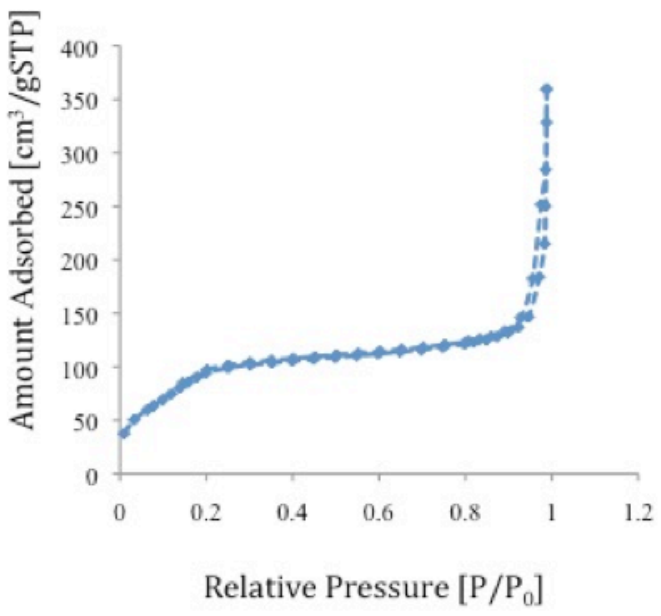

Figure 2. The small angle XRD (a) and the nitrogen sorption isotherm of B-SS-Amine-MSN. 

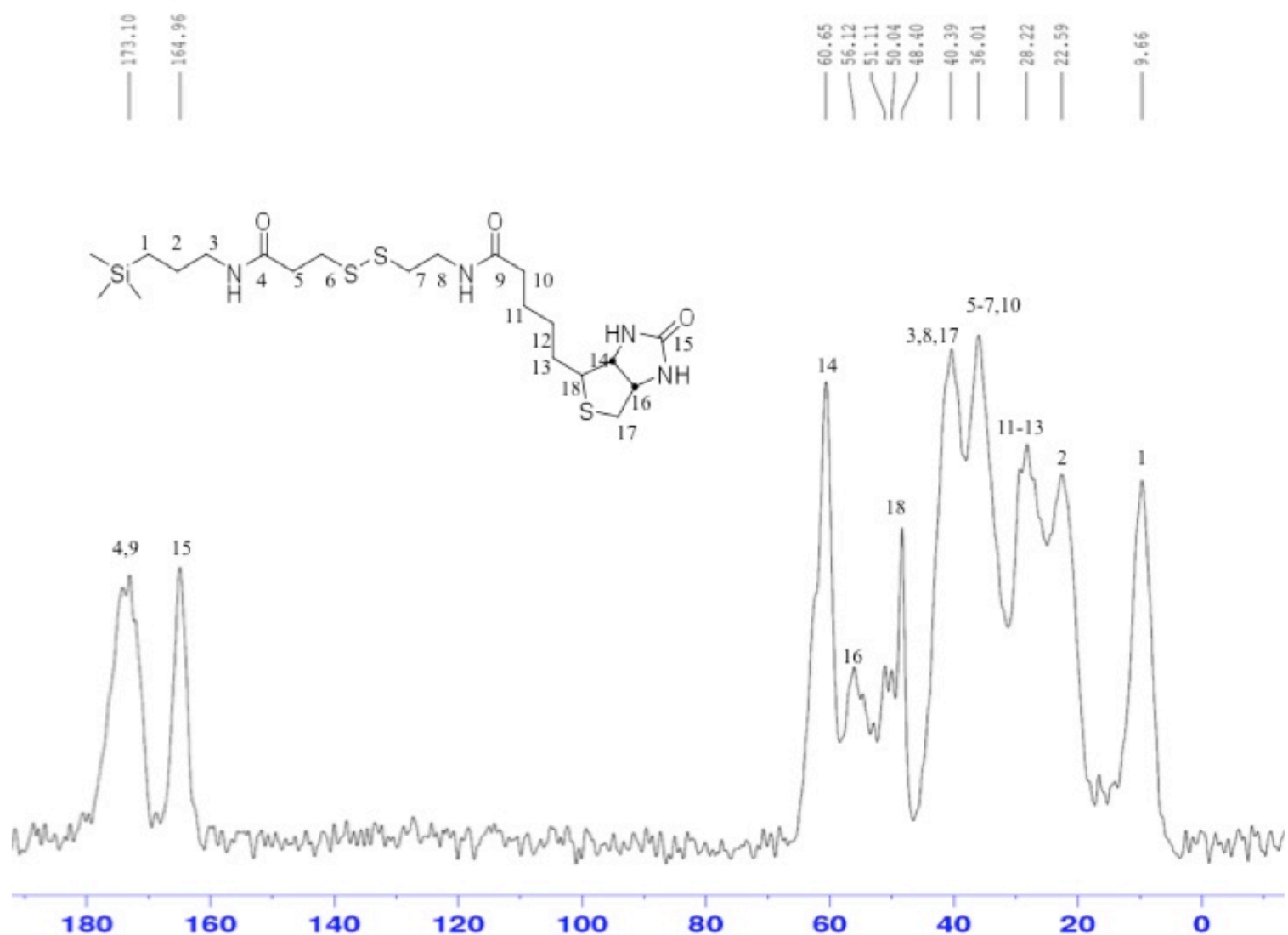

Figure 3. ${ }^{13} \mathrm{C}$ solid-state CPMAS NMR spectra of the B-SS-Amine-MSN. The characteristic peaks are identified above. 
Table 2. The zeta potential values of the MSN materials.

\begin{tabular}{|l|c|}
\hline Material & Zeta potential $(\mathrm{mV})$ \\
\hline MSN & -13.1 \\
\hline Amine-MSN & +10.9 \\
\hline B-SS-Amine-MSN & -7.2 \\
\hline Avi-B-SS-Amine-MSN & +11.9 \\
\hline $\begin{array}{l}\text { BSA-B-Avi-B-SS-Amine- } \\
\text { MSN }\end{array}$ & -27.3 \\
\hline
\end{tabular}

The basic mesoporous characteristic properties of B-SS-Amine-MSN were shown on Figure 2. B-SS-Amine-MSN showed the typical (100) peak indicating the hexagonal arrangement of mesopores in Figure 2a and a type IV isotherm showing the presence of mesopores in Figure 2b. Also it has a surface area of $706 \mathrm{~m}^{2} \mathrm{~g}^{-1}$ and pore size of $2.3 \mathrm{~nm}$. The structure of organic functional groups of B-SS-Amine-MSN and the identification of ${ }^{13} \mathrm{C}$ peaks were shown on Figure 3. The existence of the amide bonds indicated the coupling of biotin ligands was successful and the biotin ligands were linked to the surface bound aminopropyl groups covalently. Furthermore, every surface modification changed the surface potential showed on Table 2. Unfunctionalized MSN is negative $(-13.1 \mathrm{mV})$, but the aminopropyl grafting reversed the surface charge to positive. The further amide bond formation of amine-MSN with biotin ligands compensated the positive charge from aminopropyl groups. In addition, because avidin and BSA are positive and negative, respectively, at $\mathrm{pH}$ 7.4, the direction of surface charge of B-SS-Amine-MSN would change toward the native charge of proteins immobilized. For example, the deposition of avidin and BSA on MSN surface gave opposite surface charges. 
The amount of biotin, avidin, and BSA on BSA-B-Avi-B-SS-Amine-MSN were quantified by TGA and UV-Vis in Table 3. For TGA measurements, the organic content of biotin or proteins was calculated by measuring the delta of organic weight loss before and after the corresponding synthesis steps. Thus, BSA-B-Avi-B-SS-Amine-MSN has abundant surface biotin ligands for the affinity of avidin. Although BSA-biotin can be bound to avidin, the loading density of BSA-biotin was smaller than that of avidin due to the size of BSA and limited external surface of the MSN materials. The organic content values determined by TGA were consistent with the protein content determined by UVVis. On the silica surface, the deposition of avidin was greater than that of BSA-biotin. The quantity of protein immobilized on the MSN surface was determined by calculating the protein concentration in the solution before and after the deposition of proteins on the MSN. Furthermore, the biotin density was determined by the HABA assay. The HABA assay reports the amount of biotin that remains an affinity to avidin. B-SS-Amine-MSN has surface biotin in $25.5 \mu \mathrm{mol} \mathrm{g} \mathrm{g}^{-1}$.

Table 3. The quantitative analysis of BSA-B-Avi-B-SS-Amine-MSN.

\begin{tabular}{|c|c|c|}
\hline & $\begin{array}{c}\text { Organic content }(\%) \text { by } \\
\text { TGA }\end{array}$ & $\begin{array}{c}\text { Protein content }\left(\mu \mathrm{mol} \mathrm{g}^{-1}\right) \\
\text { by UV-Vis }\end{array}$ \\
\hline Aminopropyl biotin & 29.9 & N.A. \\
\hline Avidin & 11.8 & 4.76 \\
\hline BSA & 2.35 & 2.41 \\
\hline
\end{tabular}



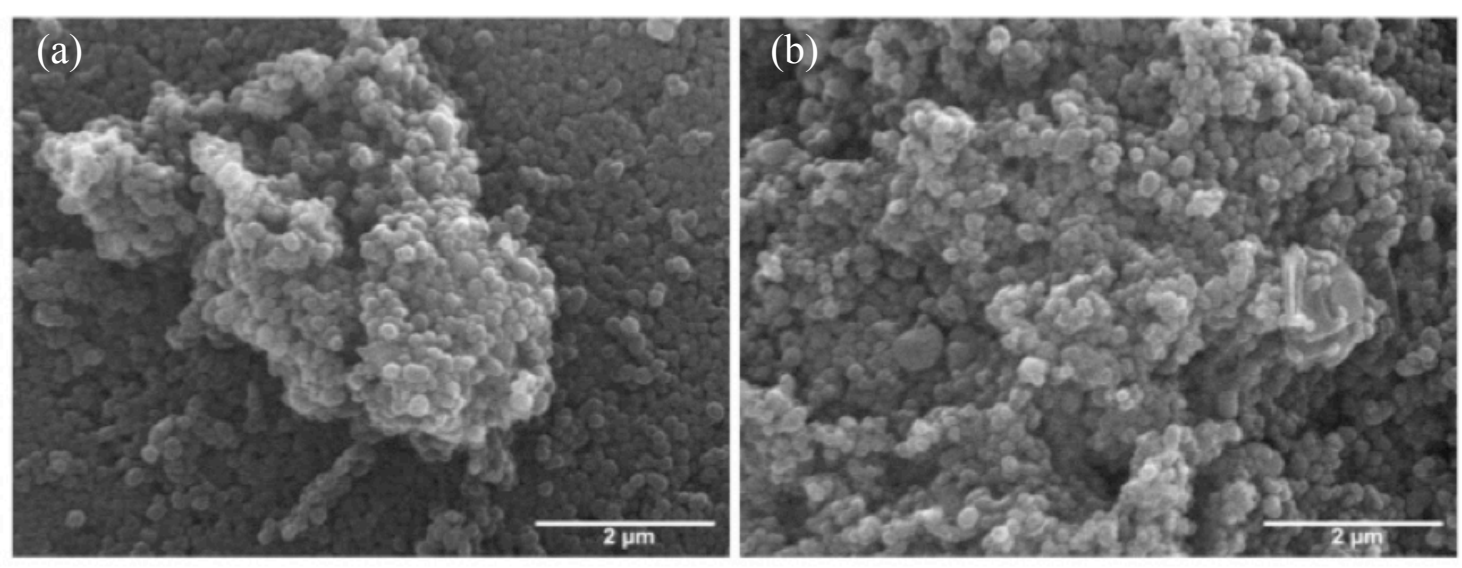

Figure 4. Scanning electron micrograph of Avi-B-SS-Amine-MSN (a) and BSA-BAvi-B-SS-Amine-MSN (b).

The size and morphology of Avi-B-SS-Amine-MSN and BSA-B-Avi-B-SS-AmineMSN were observed on Fig. 4. Both materials have spherical morphology and the range of particles size ranged from $100 \mathrm{~nm}$ to $250 \mathrm{~nm}$.

Table 3. The efficiency of DTT for the MSN materials.

\begin{tabular}{|l|c|}
\hline MSN & $\begin{array}{c}\text { Thiol density }\left(\mu \mathrm{mol} \mathrm{g}{ }^{-1}\right) \\
\text { with DTT treatment }\end{array}$ \\
\hline Avi-B-SS-Amine-MSN & $\mathbf{9 2 . 0}$ \\
\hline BSA-B-Avi-B-SS-Amine-MSN & $\mathbf{1 0 0 . 8}$ \\
\hline B-SS-Amine-MSN & $\mathbf{9 0 . 5}$ \\
\hline
\end{tabular}


When this MSN material is injected to animal tissue, they could encounter cellproduced antioxidants (ex. glutathione (GSH) or dihydrolipoic acid (DHLA)) and proteases. This disulfide reducing and protein digestive natural environment were mimicked by treating the MSN materials with DTT and trypsin. The disulfide bond is cleavable by DTT. The efficiency of DTT was tested on the three MSN materials summarized on Table 3. The thiol density was determined by a previously published method. ${ }^{32}$ After incubation with DTT reagent, all the three MSN materials have plenty surface thiol groups from 92-100 $\mu \mathrm{mol} \mathrm{g}^{-1}$. Thus, DTT can cleave the disulfide bond on MSN surface to reveal the free thiol groups with or without the immobilized proteins. In addition, DTT can reduce the disulfide bonds formed between cysteine residues that are part of both protein sequences ${ }^{33,34}$, and Avi-B-SS-Amine-MSN and BSA-B-Avi-B-SSAmine-MSN gave rise to more thiol functional groups because a few protein molecules physically adsorbed on DTT treated MSN materials.

The effect of protease on cellular uptake of protein immobilized MSN materials was also examined. The protease, trypsin, was chosen as the digestive protein for the experiment. Trypsin has previously been demonstrated to digest avidin on the MSN surface. ${ }^{18}$ The surface charge and the cellular uptake of MSN materials were summarized on Figure 5. Each material has its own cellular uptake and surface charge. The change in surface charge refers directly back to the change in MSN surface functionality. For example, the avidin deposition on B-SS-Amine-MSN gave rise to the positive surface. After the treatment of DTT or trypsin, the positive surface charge on Avi-B-SS-AmineMSN changed to a negative charge due to the disappearance of avidin. Also, BSA-B-A- 
B-SS-Amine-MSN demonstrated similar behavior. Generally speaking, positively charged MSN materials are internalized more by cells because positive nanoparticles have an electrostatic attraction to the negatively charged cell membrane. Avi-B-SSAmine-MSN has the highest cellular uptake, which corresponds to the highest positively charged surface. BSA-B-A-B-SS-Amine-MSN has the most negative surface charge and resulted in the lowest endocytosis efficiency. Before and after the DTT or trypsin treatment, the surface charge values of the MSN materials are easily distinguishable. As a result, their cellular uptake values change along with the surface charge. For example, if the treatment promotes the occurrence of the positive surface, the endocytosis efficiency will improve. The span for the adjustment of cellular efficiency ranged from 8 to $40 \mu \mathrm{g}$ $\mathrm{ml}^{-1}$, the surface charge of this series of MSN materials ranges between 11.9 and -27.3 $\mathrm{mV}$.

Avidin or BSA could also be physically adsorbed onto the MSN surface causing a change in surface charge and endocytosis efficiency. Control experiments were performed with MSN containing physically adsorbed proteins. The effect of trypsin on these control MSN materials was investigated. Avidin or BSA adsorption will change surface charge according to the protein native charge. With the treatment of trypsin, the surface charge changed. However, such a change of surface charge did not play an important role on the cellular uptake of materials. No significant difference was observed. This could be related to the lower loading density of protein on native MSN surface than on the MSN materials functionalized with biotin moiety. The loading amount was 1.26 and $0.82 \mu \mathrm{mol} \mathrm{g}^{-1}$ for avidin and BSA, respectively. The change of surface charge and the cellular uptake of this MSN material are $14.5 \mathrm{mV}$ and $6 \mu \mathrm{g} \mathrm{ml}{ }^{-1}$, respectively. 
Endocytosis of MSN internalized by HeLa was observed by the confocal fluorescence microscopy in Figure 7. Blue, red, and green colors represent the nuclear, endosome marker FM4-64, and free MSN that escaped from endosome, respectively. The colocalization of endosome marker and MSN are observed as the yellow spots in Figure 7, this yellow color comes from the overlap of red and green (endosomes and MSN materials) and represents occurrences of MSN materials that are trapped in the endosome. Avi-B-SS-Amine-MSN and B-SS-Amine-MSN were readily endocytosed by numerous cells as is evident in Figures 5 and 7, however BSA-B-Avi-B-SS-Amine-MSN was difficult to detect by confocal fluorescence microscopy. Such a difference in the observed amount of MSN materials was consistent with the previous data of cellular uptake measured by flow cytometry in Figure 5. BSA-B-Avi-B-SS-Amine-MSN showed the lowest cellular uptake value; give rise to the lowest fluorescence intensity by the confocal microscopy. 


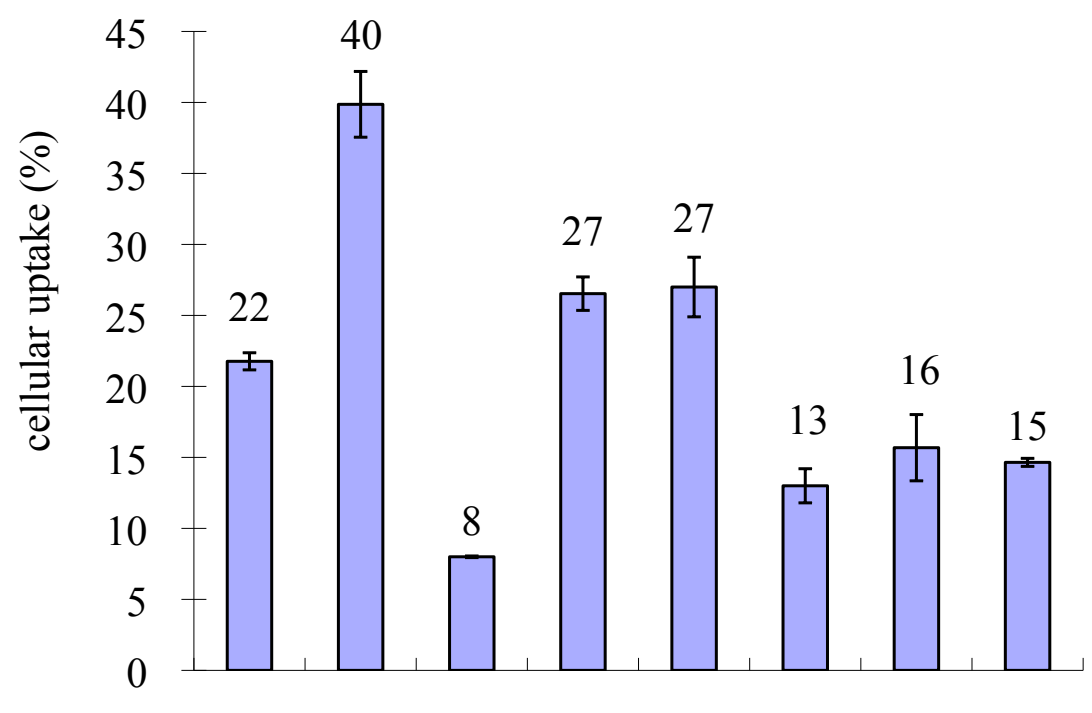

\begin{tabular}{|l|c|}
\hline Material & Zeta potential (mV) \\
\hline a. B-SS-Amine-MSN & -7.2 \\
\hline b. Avi- B-SS-Amine-MSN & +11.9 \\
\hline c. BSA-B- Avi- B-SS-Amine-MSN & -27.3 \\
\hline d. B-SS-Amine-MSN+DTT & -6.8 \\
\hline e. Avi- B-SS-Amine-MSN+DTT & -3.1 \\
\hline f. BSA-B- Avi- B-SS-Amine-MSN+DTT & -13.3 \\
\hline g. Avi- B-SS-Amine-MSN+Trypsin & -4.9 \\
\hline h. BSA-B- Avidin- B-SS-Amine-MSN+Trypsin & -17.9 \\
\hline
\end{tabular}

Figure 5. Cellular uptake of MSN $\left(1 \mu \mathrm{g} \mathrm{ml}^{-1}\right)$ materials with/ without DTT or the treatment of trypsin. 


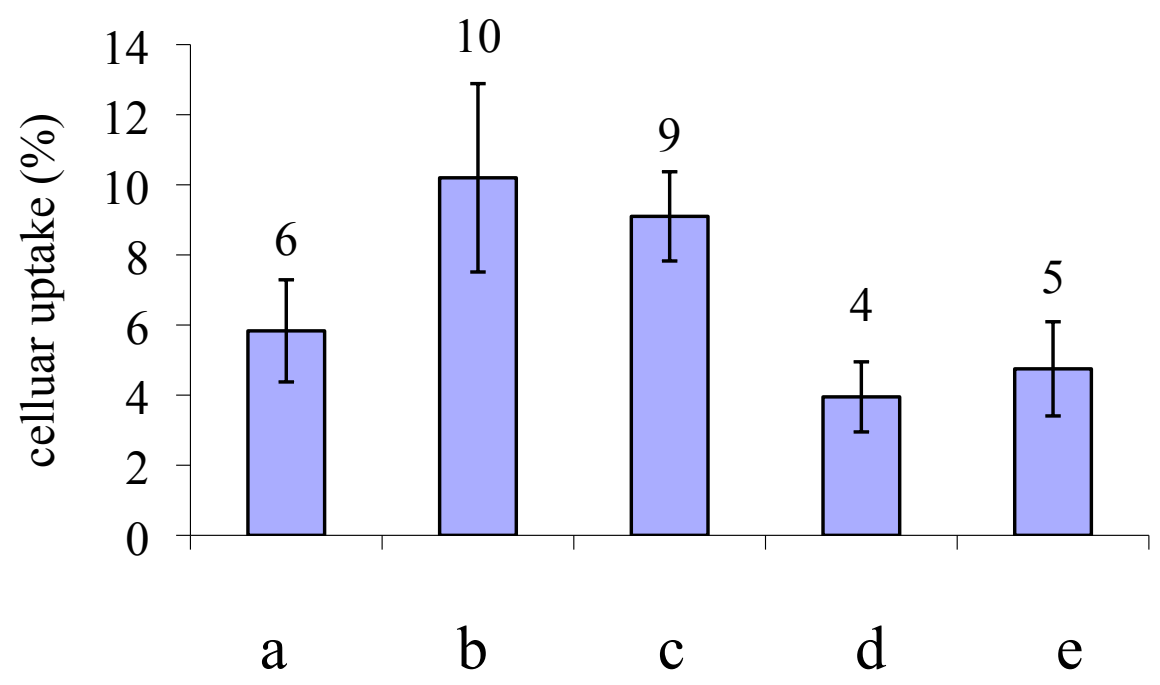

\begin{tabular}{|l|c|}
\hline Material & Zeta potential $(\mathrm{mV})$ \\
\hline a.MSN & -13.1 \\
\hline b.MSN+avidin & -3.5 \\
\hline c.MSN+avidin +trypsin & -9.9 \\
\hline d.MSN+BSA +trypsin & -18.0 \\
\hline e.MSN+BSA & -17.4 \\
\hline
\end{tabular}

Figure 6. Cellular uptake of MSN materials with/ without the treatment of trypsin. 

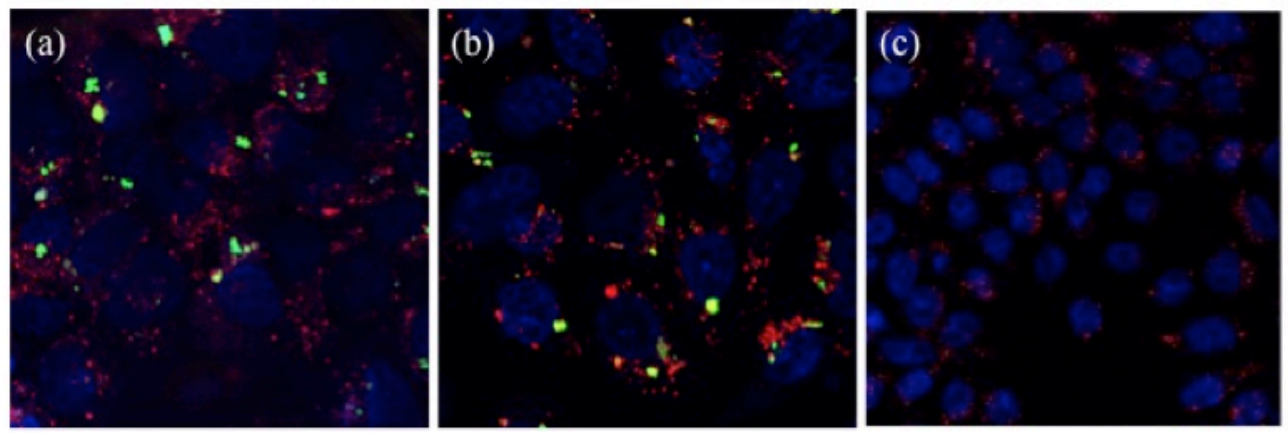

Figure 7. Fluorescence confocal micrographs of HeLa cells after a 17-h incubation with B-SS-Amine-MSN (a), Avi-B-SS-AmineMSN (b) and BSA-B- Avi-B-SS-Amine-MSN (c).

\section{Conclusions}

B-SS-Amine-MSN has a strong affinity for avidin. Avidin immobilized on MSN surface improved the accumulation of MSN materials in tumor cells. Also, avidin can be regarded as a universal linker between MSN and biotinylated biomolecules. The avidinbiotin system made it possible to selectively program the endocytosis behavior of MSN materials by depositing biomolecules of interest on the MSN surface. When these MSN materials encounter a thiol reducing reagent or a protease, they showed distinguishing endocytosis behavior that corresponded to the measured surface charge. As a result, the endocytosis uptake of MSN materials with biotin moiety can be easily adjusted. The range for cellular uptake of B-SS-Amine-MSN was much greater than the control unfunctionalized MSN. Another advantage of this system is that the cellular uptake can be adjusted in a short time period. The endocytosis efficiency can be administrated coarsely or finely. This system demonstrates that controlled uptake of MSN materials for tumor cells have potential to be practical. 


\section{Reference}

(1) Kuhn, B.; Kollman, P. A. J. Med. Chem. 2000, 43, 3786.

(2) Zempleni, J.; McCormick, D. B.; Stratton, S. L.; Mock, D. M. J. Nutr. Biochem. 1996, 7, 518 .

(3) Inoue, H.; Anzai, J. Langmuir 2005, 21, 8354.

(4) Cui, X.; Pei, R.; Wang, Z.; Yang, F.; Ma, Y.; Dong, S.; Yang, X. Biosens. Bioelectron. 2003, 18, 59.

(5) Gole, A.; Murphy, C. J. Chem. Mater. 2005, 17, 1325.

(6) Angelatos Alexandra, S.; Johnston Angus, P. R.; Wang, Y.; Caruso, F. Langmuir 2007, 23, 4554 .

(7) Deng, T.; Li, J.-S.; Huan, S.-Y.; Yang, H.-F.; Wang, H.; Shen, G.-L.; Yu, R.-Q. Biosens. Bioelectron.2006, 21, 1545.

(8) Anzai, J.-i.; Kobayashi, Y.; Nakamura, N.; Nishimura, M.; Hoshi, T. Langmuir 1999, 15, 221.

(9) Orth, R. N.; Clark, T. G.; Craighead, H. G. Biomed. Microdevices 2003, 5, 29.

(10) Prosperi, D.; Morasso, C.; Tortora, P.; Monti, D.; Bellini, T. Chembiochem 2007, 8,1021 .

(11) Masson, M.; Yun, K.; Haruyama, T.; Kobatake, E.; Aizawa, M. Anal. Chem. 1995, 67, 2212.

(12) Timalsina, Y. P.; Branen, J.; Aston, D. E.; Noren, K.; Corti, G.; Schumacher, R.; McIlroy, D. N. J. Appl. Phys. 2011, 110, 014901/1.

(13) Fu, Y.; Lakowicz Joseph, R. J. Phys. Chem. B 2006, 110, 22557 . 
(14) Gu, J.; Yam, C. M.; Li, S.; Cai, C. J. Am. Chem. Soc. 2004, 126, 8098.

(15) Tominaga, R.; Sivakumar, M.; Tanaka, M.; Kinoshita, T. J. Mater. Chem. 2008, $18,976$.

(16) Dai, Z.; Wilson, J. T.; Chaikof, E. L. Mater. Sci. Eng., C 2007, 27, 402.

(17) Schlossbauer, A.; Warncke, S.; Gramlich, P. M. E.; Kecht, J.; Manetto, A.; Carell, T.; Bein, T. Angew. Chem., Int. Ed. 2010, 49, 4734.

(18) Schlossbauer, A.; Kecht, J.; Bein, T. Angew. Chem., Int. Ed. 2009, 48, 3092.

(19) Yao, Z.; Zhang, M.; Sakahara, H.; Nakamoto, Y.; Higashi, T.; Zhao, S.; Sato, N.; Arano, Y.; Konishi, J. J. Nucl. Med. 1999, 40, 479.

(20) Hoshi, T.; Akase, S.; Anzai, J.-i. Langmuir 2002, 18, 7024.

(21) Livnah, O.; Bayer, E. A.; Wilchek, M.; Sussman, J. L. Proc. Natl. Acad. Sci. U. S. A. 1993, 90, 5076 .

(22) DeChancie, J.; Houk, K. N. J. Am. Chem. Soc. 2007, 129, 5419.

(23) Nozawa, K.; Osono, C.; Sugawara, M. Sensors and Actuators, B: Chemical 2007, B126, 632 .

(24) Xiong, M. P.; Forrest, M. L.; Karls, A. L.; Kwon, G. S. Bioconjugate Chem. 2007, $18,746$.

(25) Hsiao, A. P.; Heller, M. J. J. Biomed. Biotechnol. 2012, 178487.

(26) Spaeth, K.; Brecht, A.; Gauglitz, G. J. Colloid Interface Sci. 1997, 196, 128.

(27) Slowing, I.; Trewyn, B. G.; Lin, V. S. Y. J. Am. Chem. Soc. 2006, 128, 14792.

(28) Ikariyama, Y.; Furuki, M.; Aizawa, M. Anal. Chem. 1985, 57, 496. 
(29) Savage, M. D., Mattson, G., Desai, S., Nielander, G.W., Morgensen, S., and Conklin, E.J. Avidin-Biotin Chemistry: A Handbook, 1992.

(30) Morpurgo, M.; Hofstetter, H.; Bayer, E. A.; Wilchek, M. J. Am. Chem. Soc. 1998, 120, 12734.

(31) Janolino, V. G.; Fontecha, J.; Swaisgood, H. E. Appl. Biochem. Biotechnol. 1996, $56,1$.

(32) Ryan, K. D. Special Thiol Reagent Issue; Aldrich Chemical Company, 1971; Vol. 4.

(33) Huang, T.-S.; DeLange, R. J. J. Biol. Chem. 1971, 246, 686.

(34) Nakamura, Y.; Si, Q.-S.; Takaku, T.; Kataoka, K. J. Neurochem. 2000, 75, 2309. 


\section{CHAPTER 5. GENERAL CONCLUSIONS}

Mesoporous silica nanoparticle (MSN) materials have demonstrated their significant potential in biological applications due to their excellent drug delivery and endocytotic behavior. It was initially reported that the endocytosis of MSN materials is dependent on the surface functionality. However, there has been minimal study determining the endocytosis of MSN with bound biomolecules. Thus, we aimed to gain a greater understanding of the role of surface bound biomolecule on the behavior of endocytosis of MSN materials.

First, MSN materials were covalently functionalized with conformation specific bioactive molecules (either linear or cyclic RGD ligands). Small peptide RGD ligands on the MSN surface were tested to determine if they behave towards mammalian cells in a similar manner as the free ligands. RGD immobilized on the MSN surface did not influence the hexagonal arrangement of the porous matrix and improved the endocytosis efficiency of the MSN materials through the receptor-associated pathway. Through competition experiments with free RGD ligands, a conformation specific receptor: integrin association was discussed. The interaction between RGD immobilized on the MSN surface and integrins plays a significant role in endosome trafficking, specifically controlling the kinetics of endosomal escape. If surface bound RGD ligands are associated more strongly with cell receptor integrins, the uptake of MSN materials by cells is more effective but microscopy results indicate that their escape from endosomes is slower. Thus, covalent functionalization of biomolecules on MSN assists in the design of a system for controlling the interface with cancer cells. 
Furthermore, the exocytosis of MSN materials opens the door for additional bioapplication. Magnetic mesoporous silica nanoparticles with the desired functionality were designed for the protein sequestration study. The silica materials with the non-, amino propyl, carboxylic acid, and hydrophobic functional groups were used in the protein sequestration experiments. The normal healthy human umbilical vein endothelial cells (HUVECs) and human cervical cancer cells (HeLa) were treated with four types of materials to investigate the relationship between the silica surface bound functional group and the harvested proteins from both cell types. We determined that the cell types can be distinguished with the treatment of materials with the different functional groups. When varying the surface functional groups, mesoporous silica nanoparticle materials can transport a diverse population of intracellular proteins during the exocytosis process. Although the density of harvested protein is quite dilute, the valuable information that MSN materials could approach Golgi and ribosome is revealed. Thus, mesoporous silica nanoparticles with the designed surface could report the specific cellular process or the travel pathway of exocytosed nanoparticles.

Finally, the protein, bovine serum albumin (BSA), is noncovalently linked to the external surface of biotin functionalized mesoporous silica nanoparticle (MSN) materials through the avidin-biotin bridge with a cleavable disulfide ligand. This system was designed to identify how the biomolecule functionalization on MSN surface influences the endocytosis efficiency of mesoporous silica nanoparticles toward cancer cell HeLa. In chapter 2, small peptide RGD ligands were covalently functionalized on MSN surface. In chapter 3, the proteins were immobilized on MSN surface noncovalently. Proteins on MSN surface can be used as caps in drug delivery system or targeting ligands for 
endocytosis of MSNs into cells. A method for dual layer protein deposition on MSN surface was developed to control the endocytosis behavior toward cells. Surface bound avidin and BSA gave rise to the opposite effect for endocytosis of MSNs. These materials treated with DTT and the enzyme, trypsin, changed their endocytosis behavior as well. The endocytosis efficiency of MSNs can be administrated coarsely or finely by surface bound protein types, thiol reducing reagents, or proteases.

In summary, surface biomolecule ligands on MSN will improve the endocytosis efficiency of MSN materials. MSN materials can approach the important organelles in the cytoplasm. The combination of the advantages of endocytosis of MSN with desired functionality and information revealed by the study of the exocytosis of MSN would boost the design of well-controlled MSN-based drug delivery system. 


\section{ACKNOWLEDGEMENTS}

I would like to thank my parents and siblings for their encouragement and support in my life.

I appreciate my research advisors Dr. Brian Trewyn, Dr. Victor S.-Y. Lin and my POS committee members for their invaluable guidance during my research.

I also thank Igor Slowing, Kevin Wu, Kapil Kandel, Yannan Zhao, and other group members for their assistance on the research.

This work was performed under the U.S. National Science Foundation (CHE0809521) 